\title{
BELİRLİ SÜRELİ İŞ SÖZLEŞMESİ
}

Arş. Gör. Serkan AYAN*

\section{GíRiş}

İş sözleşmesinin türleri denilince, klasik anlamda ilk akla gelenler, iş sözleşmesinin bir süreye bağlı olarak yapılması ile belli bir süreye bağlı olmayan bir biçimde yapılmasıdır. İş sözleşmesinin süreye bağlanması ile bağlanmaması arasında, hukukî sonuçları itibariyle birçok bakımdan fark bulunmaktadır. Özellikle, iş sözleşmesinin sona erme zamanı, bildirimli fesih hakkının bulunup bulunmaması ve iş güvencesinden yararlanma bakımından, her iki sözleşme arasında esaslı farklılıklar vardır. Bu nedenle, yapılan iş sözleşmesinin belirli süreli mi, yoksa belirsiz süreli mi olduğunun tespiti, bu hukukî sonuçlar bakımından son derece önemlidir.

1475 sayılı İş Kanununda, belirli süreli iş sözleşmeleriyle ilgili ayrıntılı düzenlemeler bulunmadığı için, özellikle belirli süreli iş sözleşmesi yapma hakkının işverence kötüye kullanılması durumunda uygulanacak yaptırımın, daha doğru bir ifadeyle hukukî sonucun ne olacağı, uygulamada üretilen çözümlerle belirlenmeye çalışılmıştı. $\mathrm{Bu}$ dönemde, özellikle zincirleme iş sözleşmelerinin baştan itibaren belirsiz süreli iş sözleşmesi olarak değerlendirildiğini, bunun ise, Medenî Kanunun 2. maddesinde düzenlenen dürüstlük kuralına dayandırıldığını söyleyebiliriz.

2003 yılında yürürlüğe giren 4857 sayılı İs Kanunu ${ }^{1}$ ise, uygulamanın bulduğu bu pratik çözümleri bünyesine alarak, hatta bazı konularda daha da ileri giderek, belirli süreli iş sözleşmesini yeniden düzenlemiştir. Bu nedenle belirli süreli iş sözleşmesinin, bu yeni düzenlemeler karşısındaki durumunun incelenmesinde yarar vardır. Ayrıca 2005 yılının Ocak ayı içinde kamuoyunun bilgisine sunulan ve yakın bir zamanda kanunlaşması beklenen

Dokuz Eylül Üniversitesi Hukuk Fakültesi Medenî Hukuk Anabilim Dalı

1 RG, 10.06.2003, S. 25134. 
Türk Borçlar Kanunu Tasarısında, genel olarak iş sözleşmesi, özel olarak ise konumuz olan belirli süreli iş sözleşmeleriyle ilgili bazı yeni hükümler getirilmek istenmektedir. Bu hükümlerle, iş hukuku alanında uzun zamandır tartışmalı olan birçok konu da açık yasal düzenlemelere kavuşacaktır. Görüldüğü gibi, gerek 4857 sayılı Kanunun, gerekse de Türk Borçlar Kanunu Tasarısının yeni hükümleri, belirli süreli iş sözleşmesini incelemeye değer ve güncel bir konu haline getirmiştir.

$\mathrm{Bu}$ çalışmamızda, öncelikle belirli süreli iş sözleşmesinin tanımı, belirsiz süreli iș sözleșmesinden fark1, ardından ise, belirli süreli iş sözleşmesi yapılması için kanunen aranan objektif koşullar ve belirli süreli iş sözleşmesinin sona ermesi ile bunun hukukî sonuçları üzerinde duracağız.

\section{GENEL OLARAK BELİRLİ SÜRELİ İS SÖZLEȘMESİ}

\section{A. İş Sözleşmesi Türlerine Genel Bir Bakış}

İş Kanununun (İşK) 8. maddesinin birinci fikrasında, “... bir tarafin (işçinin) bağıml olarak iş görmeyi, diğer tarafin (işverenin) da ücret ödemeyi ..." üstlendiği sözleşme olarak tanımlanmış bulunan iş sözleşmesinde ${ }^{2}$, tüm özel hukuk ilişkilerinde geçerli olan sözleşme özgürlüğü ilkesi, kural olarak bulunmaktadır. Buna göre taraflar, Kanunun sınırları çerçevesinde, diledikleri tür ve içerikte iş sözleşmesi yapabileceklerdir. Mesela, taraflar iş sözleşmesini bir süreye bağlı olarak yapabilecekleri gibi, süreye bağlamadan da yapabilirler. Böylece iş sözleşmesinin belirli ve belirsiz süreli olarak yapılabileceği ortaya çıkmaktadır. Nitekim İşK m. 9/II'de, iş sözleşmelerinin belirli veya belirsiz süreli olarak yapılabileceği düzenlenmiştir. Aynı fikranın devamında ise, bu sözleşmelerin çalışma biçimleri bakımından farklı şekillerde düzenlenebileceği belirtilmiştir. Buna göre, belirli veya belirsiz süreli iş sözleşmeleri, çalışma biçimleri bakımından da, tam süreli - kısmî süreli ${ }^{3}$, deneme süreli ya da çağrı üzerine ${ }^{4}$ çalışma gibi biçimde oluşturulabilir.

2 Türk Borçlar Kanunu Tasarısının (TBKT) 397. maddesinin birinci fikrasına göre, "Hizmet sözleşmesi, işçinin işverene bağımlı olarak belirli veya belirli olmayan süreyle iş görmeyi ve işverenin de ona zamana veya yapılan işe göre ücret ödemeyi üstlendikleri sözleşmedir." Bu tanımda ilk dikkat çekici nokta, 2003 yılında yürürlüğe giren 4857 sayılı İș Kanununun, "İș Sözleșmesi" terimini tercih etmesine karșın, TBKT'da "Hizmet Sözleşmesi” teriminin kullanılmasıdır. $\mathrm{Bu}$ nedenle, terim birliğinin sağlanması bakımından, İş Kanununun tercihi olan "İş Sözleşmesi" teriminin, Tasarı bakımından da kullanılmasının yararlı olacağı ileri sürülebilir.

3 İş Kanununun 13. maddesinin birinci fikrasına göre, iş̧̧inin haftalık normal çalışma süresinin, tam süreli iş sözleşmesiyle çalışan emsal işçiye göre önemli ölçüde daha az belirlenmesi durumunda sözleşme kısmî süreli iş sözleşmesi sayılır.

4 İș Kanununun 14. maddesinin birinci fikrasına göre, "yazılı sözleşme ile işçinin yapmayı üstlendiği işle ilgili olarak kendisine ihtiyaç duyulması halinde iş görme ediminin yerine getirileceğinin kararlaştırıldı̆̆ iş ilişkisi, çağrı üzerine çalışmaya dayalı kısmi süreli bir iş sözleșmesidir." 
İş Kanununun 9. maddesinin bu hükmünden, iş sözleşmesinin temelde belirli veya belirsiz süreli olarak türlere ayrıldı ğı ve bu türlerin farklı çalışma biçimlerine göre düzenlenebilecekleri sonucuna varılmaktadır.

1475 sayılı İş Kanununda düzenlenmemiş bulunmakla birlikte, uygulamada kullanılan bazı çalışma biçimleri de, 4857 sayılı İş Kanunuyla yasal bir temele oturtulmuştur. Bu kapsamda, 1475 sayılı Kanunda da düzenlenmiş bulunan, sürekli - süreksiz işlerdeki iş sözleşmeleri ${ }^{5}$, deneme süreli iş sözleşmesi ve takım sözleşmesi ${ }^{6}$ dışında, tam süreli - kısmî süreli, çağrı üzerine çalışma, ödünç iş ilişkisi gibi yeni bazı çalışma biçimleri de 4857 sayılı Kanunda düzenlenmişlerdir.

\section{B. Belirli Süreli İş Sözleşmesi}

\section{Tanım}

1475 sayılı Kanunda belirli süreli iş sözleşmesinin tanımına ilişkin açık bir hüküm bulunmamaktaydı. $\mathrm{Bu}$ dönemde belirli süreli iş sözleşmesinin tanımı, BK m. 338 hükmünden dolaylı olarak çıkarılıyordu. Buna göre, “... muayyen bir müddet için yapılmıs yahut böyle bir müddet, işin maksut olan gayesinden ..." anlaşılan iş sözleşmeleri, belirli süreli iş sözleşmesidir.

4857 sayılı İş Kanunu ise, belirli süreli iş sözleşmesini tanımlamıştır. Kanunun 11. maddesine göre, "belirli süreli işlerde veya belli bir işin tamamlanması veya belirli bir olgunun ortaya çıkması gibi objektif koşullara bağlı olarak işveren ile iş̧̧i arasında yazılı şekilde yapılan iş sözleşmesi belirli süreli iş sözleşmesidir." Görüldüğü gibi bu hükümde bir tanımdan çok, belirli süreli iş sözleşmesinin unsurları düzenlenmiştir ${ }^{7}$. Diğer bir ifadeyle belirli süreli iş sözleşmesi, unsurlarına - koşullarına dayalı olarak tanımlanmıştır. $\mathrm{Bu}$ hükümden de anlaşılacağı gibi, iş sözleşmesinin bir

\footnotetext{
Nitelikleri bakımından en çok otuz iş günü süren işlere süreksiz iş, bundan fazla devam edenlere ise, sürekli iş denir (İ̧̧K m. 10/I). Görüldüğü gibi, işin sürekli olup olmamas1, işin niteliğinden çıkan bir sonuç olup, yapılan iş sözleşmesinde belirtilmiş olan süreyle ilgili değildir. Bkz. Narmanlıoğlu, Ünal: İş Hukuku Ferdi İş İlişkileri I, İzmir 1998, s. 177 (İş Hukuku); Çelik, Nuri: İş Hukuku Dersleri, B. 17, İstanbul 2004, s. 80; Süzek, Sarper: İş Hukuku, İstanbul 2005, s. 198 (İş Hukuku); Eyrenci, Öner/Taşkent, Savaş/Ulucan, Devrim: Bireysel İş Hukuku, İstanbul 2004, s. 43.

6 Birden çok işçiden oluşan bir takımı temsilen bu işçilerden birinin, takım kılavuzu sıfatıyla işverenle yaptığı sözleşmeye, takım sözleşmesi denir (İşK m. 16/I).

7 Karş. Çelik, s. 81; Alpagut, Gülsevil: "4857 Sayılı Yasa Çerçevesinde Belirli Süreli İş Sözleşmesi”, Mercek Dergisi, Ocak 2004/33, s. 74 (4857 Sayılı Yasa); Güler, Mikdat: "Belirli Süreli İş Sözleşmesi", Legal İş Hukuku ve Sosyal Güvenlik Hukuku Dergisi, 2005/5, s. 30 (Belirli Süreli).
} 
süreye bağlanmaması esas, belirli süreli yapılması ise istisnadır ${ }^{8} .4857$ sayılı Kanundan önceki dönemde de, gerek uygulama gerekse de doktrin tarafından aynı esas kabul edilmişti ${ }^{9}$. Ayrıca, iş sözleşmesinin belirli süreli mi, yoksa belirsiz süreli mi olduğu konusunda tereddüt hâsıl olduğu takdirde, iş sözleşmesinin belirsiz süreli olduğu kabul edilmekteydi ${ }^{10}$.

Doktrinde Alpagut haklı olarak, 11. maddedeki tanımı, sözleşmenin taraflarınca süreye bağlanması unsuruna yer vermemesi nedeniyle eleştirmekte ve belirli süreli iş sözleşmesini, "belirli objektif nedenlerin varlığl durumunda, taraflarca sözleşmenin sona erme anı, zaman veya tarih olarak belirlenen veya işin türü, amacı ve niteliği ile saptanan sözleşme" biçiminde tanımlamaktadır ${ }^{11}$.

4857 sayılı Kanunun bilim kurulu tarafından hazırlanan taslağında ise, mevcut hükümden daha farklı bir tanım bulunduğuna dikkat çekilmesi gerekmektedir. TBMM'deki görüşmeler sirasında mevcut halini alan bu hükümde belirli süreli iş sözleşmesi, "süresi zaman ve tarih olarak belirlenen veya işçinin üstlendiği işin türü, amact ve niteliğinden süresinin belirli olduğu anlaşılan" iş sözleşmesi olarak tanımlanmışt1 ${ }^{12}$.

Görüldüğü gibi, taslaktaki hüküm ile mevcut hüküm arasındaki en önemli fark, taslağa göre belirli süreli iş sözleşmesi yapılabilmesi için baştan objektif nedenlerin bulunmasının gerekli olmamas $1^{13}$, taraflarca bir sürenin

Süzek, İş Hukuku, s. 200; Alpagut, 4857 Sayılı Yasa, s. 77; Ulucan, Devrim: “4857 Sayılı Kanuna Göre İş Sözleşmesi Türleri”, Yeni İş Yasası Seminer Notları ve İş Kanunu, Türkiye Toprak, Seramik, Çimento ve Cam Sanayi İşverenleri Sendikası Yayını, 25-29 Haziran 2003 Çeşme, s. 39 (İşs Sözleşmesi Türleri); Tuncay, Can: "İş Sözleşmesinin Türleri ve Yeni İstihdam Biçimleri”, Yeni İş Yasası Sempozyumu, İstanbul Barosu - Galatasaray Üniversitesi, İstanbul 2003, s. 128.

9 Ekonomi, Münir: "Belirli Süreli Hizmet Akdinin Hukuka Uygunluğu”, Türk-İsviçre Hukukunda Belirli Süreli Hizmet Akitlerinin Hukuki Sorunları, Rehbinder/Ekonomi, İstanbul 1979, s. 4 (Hukuka Uygunluk). Yargitay 9. Hukuk Dairesinin 10.04.1995 tarih ve 11476/12308 sayıl1 kararından: “... Dairemizin ve Hukuk Genel Kurulunun yerleşmiş içtihatlarına göre, çalışma hayatında asıl olan belirsiz süreli hizmet akitleridir. ...” (Güler, Belirli Süreli, s. 40, dn. 25; ayrıca Eyrenci/Taşkent/Ulucan, s. 50).

Süzek, İş Hukuku, s. 200; Tuncay, İş Sözleşmesi Türleri, s. 129.

Alpagut, 4857 Sayılı Yasa, s. 74.

Bkz. Çelik, s. 82; Alpagut, 4857 Sayılı Yasa, s. 74; Güler, Belirli Süreli, s. 30; Ekmekçi, Ömer: "26 Haziran 2002 Tarihli İș Kanunu Tasarısının Bazı Hükümleri Üzerine”, Çalışma Hayatımızda Yeni Dönem Seminer Notları, 25-29 Eylül 2002 Marmaris, Türkiye Toprak, Seramik, Çimento ve Cam sanayi İşverenleri Sendikası Yayın1, s. 73.

13 Bkz. Alpagut, 4857 Sayılı Yasa, s. 77; Güler, Mikdat: "Belirli Süreli İş Sözleşmesinde Objektif Neden Kavramı ve Çalışma Koşullarının Esaslı Tarzda Değiştirilmesi - Karar İnceleme-", Legal İş Hukuku ve Sosyal Güvenlik Hukuku Dergisi, 2004/2, s. 549 (Objektif Neden); Eyrenci, Öner: "4857 Sayılı İş Kanunu ile Getirilen Yeni Düzenlemeler Genel Bir Değerlendirme”, Legal İş Hukuku ve Sosyal Güvenlik Hukuku Dergisi, 2004/I, s. 25 (Genel Değerlendirme). 
tespitinin yeterli tutulmuş bulunmasıdır. Mevcut hükümde ise, objektif neden bulunmaksızın yapılan iș sözleșmelerinin belirli süreli olarak kabulüne olanak sağlamayan ifadelere yer verilmiștir ${ }^{14}$. Böylece mevcut hükümde, belirli süreli iş sözleşmesinin varlığından söz edilebilmesi için, iş sözleşmesinin süreye bağlanmış olması yanında, objektif nedenlerin bulunması da aranmıştır ${ }^{15}$.

\section{2. Önemi}

İş Kanununda, iş sözleşmesinin belli bir süreye bağlanması ile süresiz olarak yapılması arasında gerek sözleşmenin şekli, gerek sözleşmeye uygulanacak hükümler ve gerekse de sözleşmelerin sona ermesi bakımından farkl111klar bulunmaktadir ${ }^{16}$.

Belirli süresi bir yıl ve daha fazla olan iş sözleşmeleri, kanunen yazılı şekil koşuluna bağlı tutulmuştur. Belirli süreli iş sözleşmelerinde, işçi iş güvencesinden yararlanamayacağ 1 gibi, iş sözleşmesi, belirli sürenin sonunda kendiliğinden sona ereceği için işçi, kıdem tazminatına da hak kazanamaz ${ }^{17}$.

Görüldüğü gibi işçi, belirli süreli iş sözleşmesinde birçok işçilik hakkından mahrum olmaktadır. Bu nedenlerle, belirli süreli iş sözleşmesi yapma hakk1 objektif nedenlerin varlığına bağlanmıştır. Nitekim Avrupa Birliğinin 1999/70 sayı1ı Yönergesi ile 158 sayılı ILO Sözleşmesinde, belirli süreli iş sözleşmesi yapılmasının bazı objektif nedenlere bağlanmasının gerekli olduğu ve belirli süreli iş sözleşmesiyle çalışan işçiler ile belirsiz süreli iş sözleşmesine göre çalışan işçiler arasında ayrım yapılmaması gerektiği belirtilmiştir ${ }^{18}$.

14 Alpagut, 4857 Sayılı Yasa, s. 74; Eyrenci/Taşkent/Ulucan, s. 46; Güler, Belirli Süreli, s. 31.

15 Bu konuda bkz. aşa. II. B.

16 Ancak sözleşmenin belirli veya belirsiz süreli olması, kural olarak çalışma şartları bakımından bir önem taşımaz. Bu konuda bkz. Narmanlığlu, İş Hukuku, s. 181; Narmanlıoğlu, Ünal: "Belirli Süreli İş Sözleşmesiyle Çalışan İşçinin Sözleşmesinin İşverence Haksız Halinde Kıdem Tazminatı Talep Hakkı”, Prof. Dr. Turhan Esener'e Armağan, Ankara 2000, s. 382 (Kıdem Tazminatı); Alpagut, Belirli Süreli, s. 7.

17 Süzek, İş Hukuku, s. 200; Şahlanan, Fevzi: “4857 Sayılı Yeni İş Kanunu Değerlendirme Konferansı Notları", (12-13 Temmuz 2003 Bolu), Türk İş Yayını, s. 79 (Konferans Notları); Ertürk, Şükran: "Türk ve Alman Hukukunda Belirli Süreli İş Akitlerine Genel Bir Bakış”, Prof. Dr. Turhan Esener'e Armağan, Ankara 2000, s. 226; Ekonomi, Hukuka Uygunluk, s. 1.

18 Eyrenci/Taşkent/Ulucan, s. 46; Ulucan, İş Sözleşmesi Türleri, s. 41; Alpagut, Belirli Süreli, s. 68 vd.; Tuncay, İș Sözleşmesi Türleri, s. 129; Ünal, Ayșe: “AB'de Belirli Süreli Çalışma", Kamu-İş, 2005/1, s. 80. 


\section{Belirli Süreli İş Sözleşmelerinin Diğer Bazı İş Sözleșmesi Türleriyle Karşılaştırılması}

\section{a. Belirli süreli iş sözleşmesi - Asgarî süreli iş sözleşmesi}

İş Kanununun 17. maddesine göre belirsiz süreli iş sözleşmesinde taraflar, maddedeki bildirim sürelerine uymak kaydıyla, iş sözleşmesini her zaman feshedebilirler. Anılan madde, taraflara bildirimli fesih hakkı tanımaktadır. İş sözleşmesine konulacak bir hükümle, bildirimli fesih hakkının belli bir süre ortadan kaldırılması da mümkündür. Böylece aslında belirsiz süreli olan ve tarafların bildirimli fesih hakkı bulunan bu sözleşmede, bildirimli fesih hakkı belli bir süreyle ortadan kaldırılabilir. Belirsiz süreli iş sözleșmesinde, bildirimli fesih hakkının belli bir süre kaldırılması sonucu, asgarî süreli iş sözleşmesi ortaya çıkmaktadır. Asgarî süreli iş sözleşmesi, tarafların, sözleşmenin belli bir süre devam edeceğini, bu süre içinde bildirimli fesih yoluyla sözleşmenin feshinin mümkün olmadığını, ancak bu süreden sonra bildirimli fesih yoluyla sözleșmenin feshinin mümkün olduğunu kararlaştırdıkları belirsiz süreli iş sözleşmesi türüdür ${ }^{19}$. Böylece taraflar, sözleşmenin devam edeceği asgarî süreyi kararlaştırmış olurlar. Mesela taraflar iş sözleşmesinde, sözleşmenin ilk altı ayı bildirimli fesih olanağını ortadan kaldırarak, ancak bu süreden sonra bildirimli feshin mümkün olduğunu kararlaştırmışlarsa, bu tür bir sözleşme söz konusu olur ${ }^{20}$.

Asgarî süreli iş sözleşmesinde belli bir süre bildirimli feshin yasaklanmış olması, onu belirli süreli iş sözleşmesine yaklaştırmaktadır. Çünkü belirli süreli iş sözleşmesinde de bildirimli fesih hakkı bulunmamaktadır. Bu nedenle doktrindeki bir görüşe göre, bildirimli feshin yasaklandığı süre içinde, bu sözleşmeye belirli süreli iş sözleşmesine ilişkin hükümlerin uygulanması gerekirr ${ }^{21}$.

Ancak, doktrindeki bir diğer görüş ise, her iki sözleşme arasındaki belirgin farkl1lıklara dikkat çekerek, asgarî süreli iş sözleşmesinin baştan itibaren belirsiz süreli iş sözleşmesi olduğunu vurgulamaktadır ${ }^{22}$. Çünkü belirli süreli iş sözleşmesi, sürenin sonunda kendiliğinden sona erdiği halde,

19 Alpagut, 4857 Sayılı Yasa, s. 75; Güler, Belirli Süreli, s. 33; Mollamahmutoğlu, Hamdi: "4857 Sayılı Yeni İs Kanunu'nun Getirdiği Önemli Bazı Yenilikler”, Kamu-İș İș Hukuku ve İktisat Dergisi, 2004/4, s. 9; Ulucan, Devrim: "Belirli Süreli Hizmet Akdinin Sona Ermesi", Türk-İsviçre Hukukunda Belirli Süreli Hizmet Akitlerinin Hukuki Sorunları, Rehbinder/Ekonomi, İstanbul 1979, s. 104 (Sona Erme).

22 Süzek, İş Hukuku, s. 211; Ekonomi, Münir: "Zincirleme Hizmet Akitlerinin Belirsiz Süreli Hizmet Akdine Dönüşemeyeceği Haller ve Sonuçları”, [İHU, İşK 9, (No: 4)]; Güler, Belirli Süreli, s. 34. 
asgarî süreli iş sözleşmesi, bu süre dolduktan sonra kendiliğinden sona ermemektedir. Bu tür sözleşmenin sona ermesi için, feshi ihbar gerekir. Böylece asgarî süreli iş sözleşmesi, baştan itibaren belirsiz süreli iş sözleşmesi olup, bildirimli fesih hakkının belli bir süre yasaklandığ 1 belirsiz süreli iş sözleşmesi olarak kabul edilmektedir. Diğer bir ifadeyle, asgarî süreli iş sözleşmesi baştan itibaren, bildirimli fesih hakkı asgarî bir süre ile sınırlandırılmış belirsiz süreli iş sözleşmesi sayılmaktadır ${ }^{23}$.

Doktrinde hâkim olan ikinci görüşte, asgarî süreli iş sözleşmesi, baştan itibaren belirsiz süreli iş sözleşmesi olarak değerlendirildiği için, bu sözleşmeye belirsiz süreli iş sözleşmesinin hükümleri uygulanacaktır. Hatta bildirimli fesih hakkının kaldırıldığı süre içinde bile, belirli süreli iş sözleşmesine ilişkin hükümlerin uygulanmasının mümkün olmadığı ileri sürülmüştür ${ }^{24}$.

Asgarî süreli iş sözleşmesi baştan itibaren belirsiz süreli iş sözleşmesi sayıldığg için, bu tür sözleşmenin kurulmasında, belirli süreli iş sözleşmesinin kurulabilmesi için gereken objektif nedenlerin varlı̆̆ 1 aranmayacaktır ${ }^{25}$. Taraflar, irade özerklikleri gereğince, kurdukları belirsiz süreli iş sözleşmesinde, bildirimli fesih hakkını belli bir süre ortadan kaldırabilirler. Ancak, bu ilkenin bir istisnasına 854 sayılı Deniz İş Kanununun 16. maddesinin (A) bendinde yer verilmiştir. Bu hükme göre, "Süresi belirsiz hizmet akti, 14. maddede yazıll durumlar dışında gemiadamının işe alınmasından itibaren altı ay geçmedikçe bozulamaz." $\mathrm{Bu}$ hükümde, yasaya dayalı bir asgarî süreli iş sözleşmesi düzenlenmiştir.

\section{b. Belirli süreli iş sözleşmesi - Azamî süreli iş sözleşmesi}

Taraflar, sözleşmenin devam edeceği asgarî süreyi belirleyebilecekleri gibi, azamî süreyi de belirleyebilirler. Böyle bir azamî sürenin

23 Narmanlıŏlu, İş Hukuku, s. 179.

24 Süzek, İş Hukuku, s. 211; Güler, Belirli Süreli, s. 34. Asgarî süreli iş sözleşmesinde sözleşmenin feshi halinde, işçi, koşulları varsa iş güvencesine ilişsin hükümlerden yararlanacaktır.

Bildirimli fesih hakkının kaldırıldığı süre içinde yapılan ve haklı nedenlere dayanmayan feshin hukukî sonucunun ayrıca belirtilmesi gerekmektedir. Asgarî süre içinde bile, sözleşmenin belirsiz süreli olduğu kabul edildiğinde, bu süre içinde yapılan ve haklı nedene dayanmayan feshin geçerli olduğu, ancak sözleșmenin niteliği gereği belirsiz süreli olması nedeniyle bildirim süresinin de ayrıca verilmesi gerektiği, bu sürenin ise, asgarî sürenin bitiminden itibaren başlayacağı doktrinde ileri sürülmüştür. Bkz. Güler, Belirli Süreli, s. 34. Bu görüş gereğince, asgarî süre içindeki haksız feshin tek yaptırımı, bildirim sürelerinin, asgarî sürenin sonundan itibaren işlemeye başlamasıdır. Böylece asgarî süre içindeki haksız fesih durumunda, sözleşme askıdaymış gibi düşünülmesi gerektiği ve bildirim süresinin asgarî sürenin bitiminden itibaren işlemeye başlayacağ 1 ileri sürülerek, sözleşmenin, bu bildirim süresinin sonunda ortadan kalkmış sayılacağı kabul edilmiştir.

25 Bu yönde: Alpagut, 4857 Sayılı Yasa, s. 75, 76; Güler, Belirli Süreli, s. 34. 
kararlaştırıldığ 1 iş sözleşmesinde, sözleşme sürenin sonunda kendiliğinden sona erer. Ancak bu süre içinde, tarafların bildirimli fesih haklarını saklı tutmaları da mümkündür. Süre içinde sözleşmenin feshi ihbar edilmezse, sözleşme azamî sürenin sonunda kendiliğinden sona erecektir ${ }^{26}$.

Görüldüğü gibi bu tür iş sözleşmeleri, sürenin sonunda kendiliğinden sona ereceği için belirli süreli, ancak süre içinde bildirimli fesih hakkının bulunması nedeniyle de belirsiz süreli iş sözleşmelerinin özelliklerini bünyesinde taşımaktadır. Bu nedenle, azamî süreli iş sözleşmelerinin karma bir nitelik taşıdıkları belirtilmiştir ${ }^{27}$.

Azamî süreli iş sözleşmesinde bildirimli fesih mümkün olduğu için, bu tür sözleşmeye -azamî süre içinde- belirsiz süreli iş sözleşmelerine ilişkin hükümlerin ${ }^{28}$, ancak sürenin sonunda sözleşme kendiliğinden sona ereceği için, belirli süreli iş sözleşmesi hükümlerinin uygulanması gerektiği ileri sürülmüştür ${ }^{29}$. Böylece sürenin sonunda iş sözleşmesi kendiliğinden sona ereceği için işçi kıdem tazminatına hak kazanamayacaktır.

Azamî süreli iş sözleşmeleri, süre sonunda kendiliğinden sona ereceği için, belirli süreli iş sözleşmesi yapılabilmesi için aranan objektif nedenler, bu tür sözleşmeler için de aranacaktır ${ }^{30}$. Eğer, süre sonunda kendiliğinden sona ermeyi haklı gösteren objektif nedenler bulunmazsa, yapılan sözleşme normal bir belirsiz süreli iş sözleşmesi sayılacaktır ${ }^{31}$.

\section{c. Belirli süreli iş sözleşmesi - Asgarî ve azamî süreli iş sözleşmesi}

Belirli bir süre feshinin ihbar edilemeyeceği kararlaştırılan iş sözleşmesinin, aynı zamanda belli bir süre sonra kendiliğinden sona ereceği de kararlaştırılabilir ${ }^{32}$. Bu durumda, sözleşmenin asgarî ve azamî süreli olduğu kabul edilmektedir. Bu tür iş sözleşmelerinde, asgarî bir sürenin

26 Narmanlıŏglu, İş Hukuku, s. 179; Süzek, İş Hukuku, s. 210; Alpagut, 4857 Sayılı Yasa, s. 76; Güler, Belirli Süreli, s. 35; Ulucan, Sona Erme, s. 104.

27 Alpagut, Belirli Süreli, s. 14; Alpagut, 4857 Sayılı Yasa, s. 76; Güler, Belirli Süreli, s. 35. Belirsiz süreli olduğu yönünde: Mollamahmutoğlu, s. 9.

$28 \mathrm{Bu}$ nedenle, süre içinde yapılan fesihlerde ihbar önelleri verilmelidir. Bu durumda, işçi kapsama giriyorsa iş güvencesi hükümlerinde de yararlanacaktır. Ayrıca işçi bildirimli fesihte kıdem tazminatına da hak kazanır.

29 Alpagut, 4857 Sayılı Yasa, s. 76; Alpagut, Gülsevil: "Ferdi İş İlişkisinin Sona Ermesi ve Kıdem Tazminatı Açısından Yargıtay'ın 2001 Yılı Kararlarının Değerlendirilmesi”, Yargıtay'ın İş Hukukuna İlişkin Kararlarının Değerlendirilmesi 2001, Ankara 2003, s. 90 (Değerlendirme); Güler, Belirli Süreli, s. 36.

30 Süzek, İş Hukuku, s. 210; Alpagut, 4857 Sayılı Yasa, s. 76; Güler, Belirli Süreli, s. 36.

31 Eyrenci/Taşkent/Ulucan, s. 55.

32 Ulucan'a göre, azamî ve/veya asgarî süreli iş sözleşmeleri, İş Kanununa tâbi olmayan işlerde kararlaştırılabilir. Ulucan, İş Sözleşmesi Türleri, s. 51, 52. Kanaatimce İş Kanununa tâbi işlerde de, sözleşmenin bu biçimlerde düzenlenmesine engel bir durum yoktur. 
kararlaştırılması suretiyle bu süre içinde bildirimli fesih hakkı ortadan kaldırılmakta, bu sürenin sonunda ise bildirimli fesih hakkı doğmaktadır. Ancak aynı zamanda, sözleşmenin devam edeceği azamî bir süre de kararlaştırılmak suretiyle, sözleşmenin sona ereceği en son tarih de kesin olarak tespit edilmiş olmaktadır.

Bu tür sözleşmeler asgarî süre içinde, asgarî süreli iş sözleşmesinin, bu süreden sonra ise, azamî süreli iş sözleşmesinin hükümlerine tâbi olacaktır. Böylece, asgarî süre içinde bildirimli fesih yapılması mümkün olmamasına rağmen, yinede bu süre içinde sözleşme belirsiz süreli iş sözleşmesinin hükümlerine bağlı olacağı için, bu süre içindeki fesih, bildirimli fesih sayılacak ve sözleşme, asgarî sürenin sonuna eklenecek bildirim süresinin bitiminde sona ermiş sayılacaktır. Bu durumda belirsiz süreli iş sözleşmesine ilişkin hükümler uygulanacağı için, işçi koşulları varsa iş güvencesi hükümlerinden yararlanabilir veya k1dem ve ihbar tazminatı isteyebilir. $\mathrm{Bu}$ süreden sonra ise, sözleşme azamî süreli iş sözleşmesi hükümlerine bağlı olacağı için, bildirimli fesih mümkün hale gelecek, bu süre içinde sözleşme sona erdirilmezse, azamî sürenin sonunda kendiliğinden sona erecektir. Ancak bunun için, azamî süreli iş sözleşmeleri konusunda da belirttiğimiz gibi, böyle bir azamî süreyi haklı gösteren objektif nedenlerin varlığı aranacaktır. Bu durumda, iş sözleşmesi sürenin dolmasıyla sona ereceği için, işçi kıdem tazminatına hak kazanamayacaktır.

\section{sözleşmesi}

d. Belirli süreli iş sözleşmesi - Bozucu koşula bağlanmış iş

Bilindiği gibi koşul ${ }^{33}$, hukukî işlemin sonucunun bağlandığı ve ileride gerçekleşip gerçekleşmeyeceği belli olmayan olgulardır. Ortadan kalkması, ileride gerçekleşip gerçekleşmeyeceği belli olmayan bir olguya bağlanmış hukukî işlemlere, bozucu koşula bağlanmış hukukî işlemler denir. Bozucu koşula bağlanmış hukukî işlemin hükümleri, koşulun gerçekleştiği anda kural olarak ileriye etkili biçimde ortadan kalkar (BK m. 152/II).

Bir iş sözleşmesinin sona erme anı, bu anlamda bir bozucu koşula, yani gerçekleşip gerçekleşmeyeceği belli olmayan bir olaya bağlanmışsa, bu sözleşmenin belirli süreli olarak kabulü mümkün değildir ${ }^{34}$. Çünkü belirli süreli iş sözleşmelerinin varllğı için, sözleşmenin objektif olarak belirli bir süreye bağlanması gerekmektedir. Bozucu koşula bağlı iş sözleşmelerinde ise, böyle bir belirlilik olmadığ gibi, koşulun gerçekleşip gerçekleşmeyeceği de belli olmadığı için, bu tür sözleşmelerin belirli süreli iş sözleşmesi olarak

33 Türk Borçlar Kanunu Tasarısının 175. ve devamı maddelerinde, "şart" yerine "koşul" terimi kullanıldığı için, biz de koşul terimini kullanmayı tercih ediyoruz.

34 Alpagut, Belirli Süreli, s. 15; Alpagut, Gülsevil: "Hizmet Sözleşmesinin Bozucu Şarta Bağlanması", Prof. Dr. Turhan Esener'e Armağan, Ankara 2000, s. 414 vd. (Bozucu Şart); Alpagut, 4857 Sayılı Yasa, s. 76; Ertürk, s. 232; Ulucan, Sona Erme, s. 107. 
nitelenebilmesi mümkün değildir ${ }^{35}$. Bu nedenle, koşula ilişkin hükmün geçersiz kabul edilmesi yoluyla, sözleşmenin kısmî butlan yaptırımıyla belirsiz süreli iş sözleşmesi olarak ayakta tutulması gerektiği doktrinde haklı olarak ileri sürülmüştür ${ }^{36}$.

İş sözleşmesinin sona ermesi belli bir işin bitimine bağlanmışsa, ortada bir koşul bulunduğu kabul edilemez. Çünkü bu durumda gerçekleşip gerçekleşmeyeceği belli olmayan bir olay değil, ne zaman gerçekleşeceği belli olmayan bir olayla karşı karşıya bulunulur. $\mathrm{Bu}$ nedenle gerçekleşeceği kesin olmakla birlikte, ne zaman gerçekleșeceği belli olmayan olaylara bağlanan iş sözleşmeleri, belirsiz süreli sayılmalıdır ${ }^{37}$. Ancak işin ne zaman sona ereceği sözleşmenin yapıldığı sırada taraflarca objektif olarak öngörülebiliyorsa, bu sözleşmenin belirli süreli olduğu kabul edilmelidir ${ }^{38}$.

\section{BELIRLİ SÜRELİ IŞ SÖZLEŞMESININN UNSURLARI}

\section{A. Genel Olarak}

4857 sayılı İş Kanunuyla yeniden düzenlenen belirli süreli iş sözleşmesinin varlığından bahsedilebilmesi için kanun koyucu bazı unsurların varlığını aramıştır. Ancak bunlardan önce belirtilmesinde yarar bulunan husus, bu sözleşme türünde fiil ehliyetine ilişkin genel kuralların geçerli olacağıdır. Bu nedenle bu başlık altında, sadece İş Kanununun 11. maddesinden çıarılabilen unsurlar incelenmiştir.

Bir iş sözleşmesinin Kanunun 11. maddesinin birinci fikrası anlamında belirli süreli iş sözleşmesi olarak değerlendirilmesi ve bu sözleşme türünün hukukî sonuçlarına bağlı tutulabilmesi için gereken unsurlar şöylece sıralanabilir: 1. İş sözleşmesi süreye bağlı olarak yapılmalıdır, 2. belirli süreli iş sözleşmesinin yapılması için objektif nedenlerin bulunması gerekir, 3 . belirli süreli iş sözleşmesi kural olarak yazılı şekilde yapılmalıdır ${ }^{39}$.

$\mathrm{Bu}$ unsurlar birbirinin alternatifi olan koşullar değildir. Belirli süreli iş sözleşmesinin varlığı için, bu koşulların tamamının bir arada bulunması gerekmektedir. Aksi takdirde, belirsiz süreli iş sözleşmesiyle karşı karşıya bulunulur.

35 Bozucu koşula bağlı iş sözleşmelerinin hukukî durumu hakkında ayrıntılı bilgi için bkz. Alpagut, Bozucu Şart, s. 413 vd.

36 Alpagut, Bozucu Şart, s. 426; Alpagut, 4857 Sayılı Yasa, s. 77; Güler, Belirli Süreli, s. 37.

37 Alpagut, Bozucu Şart, s. 414; Güler, Belirli Süreli, s. 36, 37; Ertürk, s. 232.

38 Bu konuda bkz. aşa. II, B, b.

39 Tuncay (İş Sözleşmesi Türleri, s. 130), belirli süreli iş sözleşmesinin unsurlarını iki başlıkta incelemektedir. Yazara göre, hukuken geçerli bir belirli süreli iş sözleşmesinin varlığı için, sözleşme objektif nedenlere dayandırılmalı ve yazılı biçimde yapılmalıdır. 


\section{B. İş Sözleşmesi Süreye Bağlı Olarak Yapılmalıdır \\ 1. Genel Olarak}

Belirli süreli iş sözleşmesinin bu unsuru, Kanunun 11. maddesinin ilk cümlesinin aksi anlamından çıkmaktadır. Bu hükme göre, iş ilişkisinin bir süreye bağlı olarak yapılmadığı durumlarda, iş sözleşmesi belirsiz sürelidir. Böylelikle, iş sözleşmelerinin belirsiz süreli olmasının asıl, belirli süreli olmasının ise istisna olduğu sonucu ortaya çıkmaktadır.

Belirli süreli iş sözleşmesinin varlığından bahsedilebilmesi için öncelikle, taraflarca iş ilişkisinin bir süreye bağlanmış bulunması gerekmektedir. Çünkü belirli süreli iş sözleşmesi yapılabilmesi için objektif nedenlerin bulunması ile iş sözleşmesinin belirli süreye bağlanması aynı kavramlar değildir. Objektif nedenler, taraflara sadece belirli süreli iş sözleşmesi yapma olanağı verir. Yoksa iş sözleşmesini doğrudan belirli süreli sözleşme haline getirmez ${ }^{40}$. Bu nedenle, belirli süreli iş sözleşmesinin ilk koşulu, iş ilişkisinin bir süreye bağlanmış olmasıdır. İş ilişkisi taraflarca bir süreye bağlanmamışsa, belirli süreli iş sözleşmesi için objektif nedenler bulunsa bile, iş sözleşmesinin belirsiz süreli olduğunun kabulü gerekecektir.

\section{Süreye Bağlanma Biçimleri}

\section{a. Sözleşmenin açıkça bir süreye bağlanması}

İş ilişkisinin süreye bağlanması farklı biçimlerde yapılabilir. Süreye bağlanma, çoğu kez belli bir takvim kesitini ifade etmektedir. Mesela, iş sözleşmesinin açıkça belli bir tarihte sona ereceğinin kararlaştırılmasında, bu tür bir sürelendirme söz konusudur. Ancak bu tür kesin bir tarih açıça belirtilmemekle birlikte, basit bir hesaplamayla elde edilebilecek bitiş tarihleri de, sözleşmeye belirli süreli nitelik verebilir. Mesela sözleșmenin, yapıldığı tarihten itibaren iki yıl için geçerli olacağı veya ihalenin

40 Bkz. Alpagut, 4857 Sayılı Yasa) s. 74; Uçum, Mehmet: Yeni İş Kanunu Seminer Notları, İstanbul 2003, s. 35; Güler, Belirli Süreli, s. 31. Ancak Süzek (İş Hukuku, s. 199), belirli süreli iş sözleşmesinin varlığı için, objektif nedenlerin bulunmasılyla birlikte, sözleşmenin süresinin açık bir tarihle belirlenmesinin yeterli olduğunu belirttikten sonra, "taraflarca bir takvim birimi belirlenmemiş bile olsa, IK11/1'de belirtilen objektif koşullarda iş akdinin ne zaman sona ereceği öngörülebildiğinden, bu tür sözleşmelerin de belirli süreli kabul edilmesi gerekir. Bununla beraber, anılan objektif nedenlerin varliğına rağmen iş akdinin taraflarının, sözleşmenin belirsiz süreli olduğunu kabul etmelerine de bir engel yoktur" yargısına varmıştır. Benzer görüşte: Demir, Fevzi: Yargıtay Kararları Işığında İş Hukuku ve Uygulaması, İzmir 2003, s. 28. Yazarın bu ifadelerinden, Kanunun 11. maddesindeki objektif nedenlerin, iş sözleşmesini doğrudan belirli süreli hale getirdiği, bunun aksinin ise açıkça kararlaştırılmaya bağlı olduğu izlenimi uyanmaktadır. Ancak, yukarıda da belirtildiği gibi, iş hukukunda olağan olan, iş sözleşmesinin belirsiz süreli olmasıdır. Objektif nedenlerin bulunması, taraflara sadece belirli süreli iş sözleşmesi yapma yetkisi verir. Yoksa sözleşmeyi doğrudan belirli süreli hale getirmez. Bu nedenle, objektif nedenlerin bulunması durumunda da, sözleşmenin belirsiz süreli olması esas, belirli süreli olması ise istisnadır. 
kesinleşmesinden itibaren üç yıl için iş sözleşmesi yapılmasında durum böyledir. Burada önemli olan konu, zamanın takvime göre belirli veya belirlenebilir olmasıdır. İş sözleşmesinde böyle bir açıklık bulunması durumunda, yani iş sözleşmesinin sona ereceği zaman, sözleşmenin yapıldığg tarihte belirli veya belirlenebilir nitelikteyse, diğer koşulların da varlığı halinde, belirli süreli iş sözleşmesi kurulmuş sayılır ${ }^{41}$.

\section{b. Sözleşmenin örtülü biçimde süreye bağlanması}

İş sözleşmesinin taraflarca yukarıdaki gibi açık biçim biçimde süreye bağlanması dışında, örtülü olarak süreye bağlanması da mümkündür ${ }^{42}$. Bu çoğunlukla, yapılacak olan işin türünden, amacından veya niteliğinden anlaşılabilir. Ancak, yapılacak olan işin türünden, amacından veya niteliğinden, o işin bir süreye bağlı olduğunun anlaşılmasının, o işle ilgili sözleşmeleri doğrudan belirli süreli iş sözleşmesi haline getirip getirmeyeceği ayrıca incelenmelidir.

BK m. 338/I hükmünde, iş sözleşmesinin belirli bir süre için yapılmış olması dışında, böyle bir sürenin işin amacından anlaşıldığı durumlarda da kural olarak iş sözleşmesinin belirli süreli olduğu düzenlenmiştir. Böylece, iş sözleşmesinde açık bir biçimde sözleşmenin belirli süreli olduğu kararlaştırılmamış olsa bile, işin amacından o işin belirli süreli olduğu anlaşılıyorsa, iş sözleşmeleri aksi kararlaştırılmadıkça belirli süreli sayilacaktır.

Sözleşme süresinin işin amacından anlaşıldığ 1 durumlara örnek olarak, bir iş gezisi veya belli bir yolculuk için bir şoförün işe alınması, hastalık veya doğum izninde bulunan bir işçi yerine, onun işini görmesi için bir işçinin alınması, inşaatta eksik kalmış işlerin yaptırılması amacıyla bir iş̧̧i alınması gibi durumlar gösterilmektedir ${ }^{43}$.

İşin türünden, amacından veya niteliğinden, o işle ilgili sözleşmenin belirli süreli olduğu anlaşılıyorsa, salt amacın veya işin niteliğinin, o işle ilgili iş sözleşmelerini belirli süreli hale getirmeyeceği doktrinde haklı olarak ileri sürülmüştür ${ }^{44}$. İşin amacından veya niteliğinden, sözleşmenin belirli

41 Alpagut, Belirli Süreli, s. 8; Alpagut, 4857 Sayılı Yasa, s. 75; Güler, Belirli Süreli, s. 31; Ulucan, Devrim: "Belirli Süreli Hizmet Akdinin Sona Ermesinde İhbar Tazminatı İstenememesi", [İHU, İşK 13 (No: 10)]; Narmanlığlu, Kıdem Tazminatı, s. 382.

42 Bkz. Narmanlıoğlu, İș Hukuku, s. 179; Sur, Melda: "Belirli Süreli Hizmet Akitlerinin Sona Ermesine İlişkin Bazı Yargı Kararlarının Değerlendirilmesi”, AÜSBFD, 1985/1-4, s. 269; Ertürk, s. 226.

43 Süzek, İş Hukuku, s. 200; Alpagut, Belirli Süreli, s. 10.

44 Alpagut, Belirli Süreli, s. 10; Güler, Belirli Süreli, s. 31; Arslan, Arzu: "Yargıtayın Belirli/Belirsiz Süreli Hizmet Sözleşmesi Nitelendirmesine İlişkin Bir Kararı Üzerine", Prof. Dr. Nuri Çelik'e Armağan, C. 2, İstanbul 2001, s. 1051; Ulucan, [İHU, İşK 13 (No: 10)]; Meyer, Daniel: "İsviçre Hukukunda Hizmet Akitlerinin Uyulması Zorunlu Olmayan Süreye Bağlanmaları" (Çev. Eyrenci, Öner), Türk-İsviçre Hukukunda Belirli Süreli Hizmet Akitlerinin Hukukî Sorunları, Rehbinder/Ekonomi, İstanbul 1979, s. 35. 
süreli olduğunun anlaşılabilmesinin, iş sözleşmelerini belirli süreli hale getirebilmesi için öncelikle, iş sözleşmesinin, ilgili iş için yapıldığı taraflarca anlaşılabilir olmalıdır. Alpagut bunu, sözleşmenin yapılmasına yönelik amacın işçiye açılanması olarak ifade etmiştir ${ }^{45}$. Buna göre, öncelikle işçi, iş sözleşmesinin yapıldığı tarihte, amacından veya niteliğinden belirli süreli olduğu anlaşılan bir işte çalıştırılacağını anlamalıdır ${ }^{46}$. Mesela işveren, bir yıl sürecek bir inşaat için işçi almışsa, sözleşme yapıldığı sırada işçinin bu inşaatın yapımı için işe alındığını anlayabilecek durumda olması, işçinin bu konuda aydınlatılması gerekmektedir. Bu işte işverenin amacı, işçiyi sadece bu inşaat bitene kadar çalıştırmak ise, bu amacını, sözleşme yapılırken işçiye iletmesi gerekmektedir. Diğer bir ifadeyle, işin amacının, her iki tarafça da sözleşmenin yapıldı̆̆ sırada objektif olarak anlaşılabilir olması gerekmektedir. Böylece işçi, işin bitmesiyle iş sözleşmesinin sona ereceğini de anlamış bulunmalıdır.

İşin amacının veya niteliğinin işçi tarafından anlaşılması yanında, aynı zamanda bunun, sürelendirme niteliği taşıdığı da objektif olarak anlaşılır olmalıdır $^{47}$. Alpagut ${ }^{48}$ bunu şu şekilde ifade etmiştir: “... hizmet ediminin amacı sözleşmenin kurulması anında işverenin işçiyi istihdamı için salt bir

45 Alpagut, Belirli Süreli, s. 10.

46 Eyrenci/Taşkent/Ulucan, s. 48; Alpagut, 4857 Sayılı Yasa, s. 75; Süzek, İş Hukuku, s. 200; Ulucan, Sona Erme, s. 105; Ulucan, [ïHU, İşK 13 (No: 10)]. Güler, işin niteliğinden veya amacından belirli süre devam edeceğinin önceden taraflarca, özellikle de işçi tarafindan bilinmesi gerektiğini belirtmiştir (Güler, Belirli Süreli, s. 31). Yargıtay, iş sözleşmesinde, sözleşmenin süresinin maden ocağındaki kuyu ve galerilerin bitim tarihi olarak belirlendiği bir olayda, işçinin belirli süreli iş sözleşmesiyle çalıştığını benzer gerekçelerle kabul etmiştir [9. HD, 13.09.1977, 10272/12560, İHU., İş 13 (No: 10)]. Bu yönde: 9. HD, 10.03.1998, 1997/20294 E., 1998/3771 K. sayılı kararı (Arslan, s. 1047, 1048). Benzer bir kararda da, iş sözleşmesinin yapıldığı sırada işçinin, belirli süreli bir iş için işe alındığını bildiğinin kanıtlanamamış olması nedeniyle, iş sözleşmesinin belirsiz süreli olduğu sonucuna varılmıştır [9. HD, 21.04.1966, 2874/3217, (Güler, Belirli Süreli, s. 31, 32, dn. 4)]. Bu yöndeki 9. HD, 22.09.2003 tarih ve 2003/2474 E., 2003/15155 K. sayılı kararından: "... iş sözleşmesinin 4. maddesinde 'sözleşmenin geçerliliğinin Bartın-Amasra yolunun yapım işlerinin tamamlanması süresi sonuna kadar devam eder' kuralına yer verilmiştir. Sözleşmenin geçerlilik tarihi olarak belirtilen yol yapım ișinin ne zaman sona ereceği konusunda somut bir tarih bulunmamaktadır. Diğer bir anlatımla işin bitiş tarihi öngörülemez. Böyle olunca bu sözleșmenin belirli süreli is sözleșmesi olduğundan söz edilemez..." (Bu karar eHukukRehberi bilgi arşivinden alınmıştır). Bu yönde: Yargıtay 9. Hukuk Dairesinin 10.03.1998 tarih ve 1997/20294 E., 1998/3771 sayılı kararından: “... Barajın bitim tarihine kadar çalıșılacağına ait sözleşmeler, belirsiz süreli sözleşmelerdir...” (Bu karar eHukukRehberi bilgi arşivinden alınmıștır).

47 Güler, Belirli Süreli, s. 32; Arslan, s. 1050.

48 Alpagut, Belirli Süreli, s. 10; Alpagut, 4857 Sayılı Yasa, s. 75. Yazar bu durumu, şu örnekle açıklamaktadır. Bir inşaat firmasının işe aldığı bir elektrik teknisyeninin belli bir binanın tesisatı için görevlendirilmesinde, tarafların bu yönde iradeleri bulunmadıkça, iş̧̧inin belirli süreli iş sözleşmesiyle çalıştırıldığı söylenemez. Çünkü burada, inşaatın bitimi ile iş sözleşmesinin de sona ereceği konusunda hukukî bir açıklık bulunmamaktadır. 
saik niteliğinde olmayı aynı zamanda amacın belirlenmesi sürelendirme anlamında ifade edilmiş olmalı ve iş̧̧i de amacın bildirilmesini bir süre belirleme olarak anlamalıdır."

İşin amacının veya niteliğinin, iş sözleşmelerini belirli süreli sözleşme niteliğine getirebilmesi için bunların yanında, amacın gerçekleşme anı veya işin bitme tarihi, sözleşmenin yapıldığı sırada objektif olarak belirlenebilir olmalıdır $^{49}$. Nitekim Yargıtay Hukuk Genel Kurulunun konuya ilişkin bir kararında $^{50}$, bir baraj inşaatının bitimine kadar devam edecek olan iş sözleşmesi, baraj inşaatının uzun süre devam edecek bir iş olması dolayısıyla inşaatın sona erme anının öngörülebilir olmaması dikkate alınarak, belirsiz süreli iş sözleşmesi kabul edilmiştir. Böylece Yargitay, işin niteliğinden belirli süreli olduğunun anlaşılmasına rağmen, çok uzun süre devam edecek işlerde, işin bitiş tarihinin objektif olarak sözleşme yapıldığ 1 sırada işçi için öngörülemez olması durumunda, iş sözleşmesinin belirsiz süreli olduğunu kabul etmiştir ${ }^{51}$.

$\mathrm{Bu}$ nedenlere, iş sözleşmesinin örtülü biçimde süreye bağlandığ1 durumlarda, iş sözleşmesinin kural olarak belirsiz süreli olduğu doktrinde ileri sürülmüştür ${ }^{52}$. Aksinin, yani iş sözleşmesinin belirli süreli olarak yapıldığının kabulü için, sözleşmenin sona ereceği tarihin sözleşmenin yapıldığı sırada, işçi için objektif olarak öngörülebilir olması gerekir. Eğer böyle bir belirlilik bulunmuyorsa, iş sözleşmesi belirsiz süreli sayılacaktır. Nitekim doktrinde haklı olarak, belirli süreli iş sözleşmesinin, sözleşmenin devam süresinin taraflarca kararlaştırıldığı değil, sözleşmenin sona erme anının taraflarca bilindiği veya öngörülebildiği sözleşme olduğu vurgulanmıştır ${ }^{53}$.

49 Çelik, s. 83; Narmanlıŏglu, Kıdem Tazminatı, s. 382; Eyrenci/Taşkent/Ulucan, s. 47; Sur, s. 269; Alpagut, 4857 Sayılı Yasa, s. 74; Tuncay, İş Sözleşmesi Türleri, s. 130; Güler, Belirli Süreli, s. 32; Ertürk, s. 231; Arslan, s. 1050; Ulucan, [IHHU, İşK 13 (No: 10)]; Meyer, s. 33, 34.

50 YHGK, 07.10.1998, 9-647/687 E/K. sayılı kararı (Tuncay, İş Sözleşmesi Türleri, s. 130; ayrıca Eyrenci/Taşkent/Ulucan, s. 47).

51 Yargitay 9. Hukuk Dairesinin 22.09.2003 tarih ve 2274/15155 sayılı kararından: “... Sözleşmenin geçerlilik tarihi olarak belirtilen yol yapım işinin ne zaman sona ereceği konusunda somut bir tarih bulunmamaktadır. Diğer bir anlatımla işin bitiş tarihi öngörülemez. Böyle olunca, bu sözleșmenin belirli süreli iş sözleșmesi olduğundan bahsedilemez..." (Legal İş Hukuku ve Sosyal Güvenlik Hukuku Dergisi, 2004/1, s. 215, 216). Aynı yönde bkz. 9. HD, 10.03.1998, 1997/20294 E., 1998/3771 K. say1lı kararı (TÜHIS., 1998/8, s. 49, 50; ayrıca bkz. Güler, Belirli Süreli, s. 32, 33, dn. 6].

52 Bkz. Tuncay, İş Sözleşmesi Türleri, s. 130; Arslan, s. 1053.

53 Alpagut, Belirli Süreli, s. 7. 


\section{Belirli Süreli İş Sözleşmesinin Yapılması İçin Objektif Nedenlerin Bulunması Gerekir \\ 1. Genel Olarak}

Kanun koyucu, sürenin taraflarca belirlendiği her durumda belirli süreli iş sözleşmesi bulunmasını, bu sözleşmenin bazı işçilik haklarını sınırlaması nedeniyle uygun görmemiş ve iş ilişkisinin süreye bağlanmasını objektif koşulların varlığına bağlamıştır ${ }^{54}$. $\mathrm{Bu}$ koşullar bulunmadan yapılacak iş sözleşmeleri, taraflarca açık bir biçimde süreye bağlansa da bunlar belirsiz süreli iş sözleşmesi sayılacaktır ${ }^{55}$. Bunun yanında, belirli süreli iş sözleşmesi yapılması için kanunda aranan nedenler bulunsa bile, iş sözleşmesi, yukarıdaki biçimde süreye bağlanmamışsa, sözleşme belirsiz süreli olma niteliğini korur. Çünkü belirli süreli iş sözleşmesi yapma hakk1 veren nedenler ile iş sözleşmesinin süreye bağlanması farklı kavramlardır.

4857 sayılı Kanunla getirilen bu düzenleme öncesindeki dönemde, belirli süreli iş sözleşmesi yapılmasını sınırlayan tek hüküm, Medenî Kanunun 2. maddesinde düzenlenmiş bulunan dürüstlük kuralıydi ${ }^{56}$. Bu dönemde Yargitay kararlarıyla getirilmiş ilkelere göre, özellikle zincirleme iş sözleşmelerinde haklı nedenlerin bulunması aranmış ve işverenin davranışının, hakkın kötüye kullanımı niteliğinde olduğu durumlarda, iş sözleşmeleri baştan itibaren belirsiz süreli sayılmışıır ${ }^{57}$.

Kanun koyucunun, belirli süreli iş sözleşmesi yapılabilmesini objektif nedenlere bağlamasının nedeni, belirli süreli iş sözleşmesinin niteliğidir. Bilindiği gibi, bu sözleşmenin sürenin sonunda kendiliğinden sona ermesi ve bu durumda işçinin kıdem tazminatı isteyememesi, uygulamada işverenlerce kötüye kullanılmış ve gerekli gereksiz yere birçok iş sözleşmesi, belirli

54 Bkz. Çelik, s. 81; Süzek, İş Hukuku, s. 199; Sur, s. 270; Rehbinder, Manfred: "Hizmet Akitlerinin Süreye Bağlanmasını Haklı Kılan Objektif Nedenler”, (Çev. Eyrenci, Öner), Türk-İsviçre Hukukunda Belirli Süreli Hizmet Akitlerinin Hukuki Sorunları, Rehbinder/Ekonomi, İstanbul 1979, s. 41; Güler, Belirli Süreli, s. 28. Belirli süreli iş sözleşmesi yapma hakkının objektif koşullara bağlanması günümüz iş hukukunun bir eğilimi olmakla birlikte, Almanya'da işsizlikle mücadele edilebilmesi amaciyla, belirli süresi iki yıldan az olan iş sözleşmelerinin yapılması için objektif neden bulunmasının gerekli olmadığı kabul edilmiştir. Bkz. Tuncay, İş Sözleşmesi Türleri, s. 129. Bu konuda ayrıca bkz. Alpagut, Belirli Süreli, s. 37 vd.; Alpagut, 4857 Sayılı Yasa, s. 78; Ertürk, s. 228 vd. Avrupa Birliğindeki aynı eğilim için bkz. Ünal, s. 76.

55 Demir (s. 28), objektif koşullar bulunmasa bile, sözleşme özgürlüğü ilkesi gereğince, tarafların iş sözleşmesini belirli süreli olarak yapmalarının mümkün olduğunu ileri sürmektedir. Kanaatimce, 4857 sayılı Kanunun 11. maddesinin açıklığı karşısında bu görüş kabul edilemez.

56 Ertürk, s. 226.

57 Çelik, s. 85; Süzek, İş Hukuku, s. 205; Sur, s. 271; Alpagut, Belirli Süreli, s. 57 vd; Alpagut, 4857 Sayılı Yasa, s. 77; Şahlanan, Konferans Notları, s. 79; Güler, Belirli Süreli, s. 37. 
sürelere bağlanmaya çalışılmıştır. Ayrıca, belirli süreli iş sözleşmesinde işçinin iş güvencesinden yararlanamaması $\mathrm{da}$, bu sözleşme türünün işverenlerce kullanılmak istenmesinin nedenleri arasındadır ${ }^{58}$.

Belirli süreli iş sözleşmelerinin işçi aleyhine olan bu özellikleri nedeniyle, iş hukukunun işçiyi koruma özelliği gereğince, belirli süreli iş sözleşmesi yapma hakkı, bazı objektif nedenlere bağlanmıştır. Böylece, Anayasa'da yer alan sözleşme özgürlüğü ilkesine de, zayıf durumda bulunan işçileri korumak amaciyla bir istisna getirilmiştir ${ }^{59}$.

\section{Objektif Nedenler}

Belirli süreli iş sözleşmesi yapılması için hangi durumların objektif neden olarak kabul edilebileceği, belirli süreli iş sözleşmesini tanımlayan İş Kanununun 11. maddesinin birinci fikrasında belirtilmiştir. Buna göre işin, niteliği gereği belirli bir süre devam etmesi, belli bir işin tamamlanması veya belli bir olgunun ortaya çıkması gibi durumlar objektif neden olarak düzenlenmiştir.

Görüldüğg̈ gibi Kanunda, objektif nedenler sınırlı biçimde değil, saymaca yöntemiyle belirtildiği için, benzer bazı durumlar da, belirli süreli iş sözleşmesinin yapılması için objektif neden olarak değerlendirilebilir ${ }^{60}$.

İş Kanunumuz iş sözleşmesinin ilk yapıldığı sırada bile objektif nedenleri aramaktadır ${ }^{61}$. Objektif nedenler bulunmaksızın yapılan iş sözleşmesi belirsiz süreli iş sözleşmesi sayılacaktır. İlk sözleşme sırasında objektif nedenler bulunması nedeniyle belirli süreli iş sözleşmesinin yapılması üzerine, bu sözleşmenin süresinin sonunda yeniden belirli süreli iş sözleşmesi yapılabilmesi için, 11. maddenin üçüncü fikrasında "esaslı neden" bulunması aranmıştır. Doktrinde de ifade edildiği gibi, aynı maddenin birinci fikrasındaki "objektif neden" ile üçüncü fikrasındaki

58 Çelik, s. 84; Eyrenci/Taşkent/Ulucan, s. 45; Alpagut, Belirli Süreli, s. 25 vd.; Güler, Belirli Süreli, s. 38.

9 Belirli süreli iş sözleşmesi yapma hakkının sınırlayan çeşitli görüşler için bkz. Alpagut, Belirli Süreli, s. 43 vd.; Sur, s. 273.

60 Süzek, İş Hukuku, s. 199; Tuncay, İş Sözleşmesi Türleri, s. 131; Güler, Belirli Süreli, s. 41; Güler, Objektif Neden, s. 549 vd.

61 Alpagut, ilk kez yapılan sözleşmelerde objektif nedenlerin aranmasının bütün durumlarda yerinde olmadığını, mesela, "ilk kez çalıșma yașamına giren veya belirli bir süre İșKur'a ișsiz olarak kayıtlı bulunan kişilerle ya da yeni bir faaliyete başlayan, faaliyet alanını genişleten ișverenler bakımından objektif neden aranmaksızın sınırlı bir süreyle belirli süreli iș sözleşmesinin kurulabilmesi yönünde bir hukuki yapı"nın oluşturulmasının yerince olacağını ileri sürmüstür. Alpagut, 4857 Sayılı Yasa, s. 78. Benzer görüste: Sahlanan, Konferans Notları, s. 80; Şahlanan, Fevzi: "Yeni İş Kanunu Ne Getiriyor Semineri", 3 Temmuz 2003 İzmir, TİSK. Yayını, s. 39 (Seminer). 
"esaslı neden" aynı kavramı ifade etmek için kullanılmış farklı terimlerdir" $\mathrm{Bu}$ nedenle, bu başlık altında incelenecek olan nedenler, hem iş sözleşmesinin ilk yapıldığı sırada, hem de sürenin sonunda yapılacak diğer belirli süreli iş sözleşmelerinde uygulama alanı bulacaktır.

\section{a. İş sözleşmesine konu olan işin belirli bir süre devam etmesi (işin belirli süreli olması)}

Bir işin geçici bir süre devam edecek olması, taraflara belirli süreli iş sözleşmesi yapma yetkisi vermektedir. Doktrinde ${ }^{63}$ belirli süreli iş, "sözleşmenin yapılması sırasında işin sona erme anının bilindiği veya öngörülebildiği" iş olarak tanımlanmıştır. Bir işin belli bir süre devam edecek olması, bu iş için yapılan bütün iş sözleşmelerine kendiliğinden belirli süreli sözleşme niteliği kazandırmaz. Bunun için ayrıca tarafların iş sözleşmesini süreye bağlamaları da gerekir.

İşin devam edeceği süre 3-5 ay gibi bir süre olabileceği gibi, 3-5 y1llık bir süre de olabilir. Bu nedenle işin devam süresi, belirli süreli iş sözleşmesi yapılabilmesi için önem taşımaz. Önemli olan, işin belli bir süre devam edecek olmasıdır ${ }^{64}$.

İşin belirli süre devam etmesinin, objektif bir neden olarak, sözleşme konusu işin baştan itibaren belirli bir süre devam edeceğinin işçi ve işveren tarafindan bilinmesini ifade ettiği, ancak bu bilme olgusunun mutlak bir anlama sahip olmadığı, yani işin bitiş tarihinin tam ve kesin olarak bilinmesinin gerekli olmadığı, objektif bir bakış açısıyla işin belli bir süre sonra sona ereceğinin anlaşılmasının yeterli olduğu doktrinde ileri sürülmüştür ${ }^{65}$. Özellikle yol ve baraj inşaatı işlerinde işin çok uzun bir süre devam edecek olmasının, sözleşmenin sona ereceği tarihin taraflarca, sözleşmenin yapıldığ sırada objektif olarak öngörülebilmesine engel olması nedeniyle, bu tür uzun işlerde -daha doğrusu bitiş tarihi taraflarca özellikle de işçi tarafından öngörülemeyen işlerde- belirli süreli iş sözleşmesi yapılamayacăğ kabul edilmektedir ${ }^{66}$.

Çelik, s. 81, 85; Eyrenci/Taşkent/Ulucan, s. 50; Eyrenci, Genel Değerlendirme, s. 26; Güler, Objektif Neden, s. 552; Güler, Belirli Süreli, s. 42. Bu terim farklılığı, 11. maddenin TBMM'ndeki görüşmeleri sırasında tasarıda yapılan değişikliklerden kaynaklanmaktadır.

63 Alpagut, 4857 Sayılı Yasa, s. 78. Bu yönde: Eyrenci/Taşkent/ Ulucan, s. 47.

64 Bkz. Tuncay, İş Sözleşmesi Türleri, s. 130.

65 Süzek, İş Hukuku, s. 201; Güler, Belirli Süreli, s. 42.

66 Bu konuda bkz. yuk. II, B, 2, b. 
Belirli bir süre devam edecek işlere örnek olarak; inşaat işleri, mevsimlik işler ${ }^{67}$ ve kampanya işleri, alınmış yüksek miktardaki bir siparişin tamamlanabilmesi için yapılacak iş sözleşmeleri gösterilebilir ${ }^{68}$.

\section{olması}

b. İş sözleşmesinin bir işin tamamlanması amacıyla yapılmış

Bir işin tamamlanması da niteliği itibariyle belirli bir süre devam eden iş kapsamında değerlendirilebilir ${ }^{69}$. Mesela bir inşaatın devamı boyuca geçerli olacak iş sözleşmeleri bu niteliktedir. Görüldüğü gibi bir işin tamamlanması, aslında işin belirli bir süre devam etmesinden farklı bir durum değildir. Doktrinde de ileri sürüldüğü gibi, kanun koyucunun bu durumu ayrı bir objektif neden olarak düzenlemesinin nedeni; başlanmış, ancak yarım bırakılmış işlerin tamamlanması için yapılacak iş sözleşmelerinin de belirli süreli olarak düzenlenebileceğini vurgulamak istemesidir $^{70}$.

\section{c. Belirli bir olgunun ortaya çıkması}

Belirli bir olgunun ortaya çıkması kavramı çok genel ve soyut bir kavramdır ${ }^{71}$. $\mathrm{Bu}$ nedenle birçok durum, belirli bir olgu olarak nitelendirilebilir. Mesela ekonominin bozulması, siparişlerin azalması, işletmenin küçülmeye başlaması, greve gidilmesi gibi durumlar, hep belirli bir olgu olarak değerlendirilebilir. Ancak, Kanunun 11. maddesi anlamında dikkate alınacak olan olgular, belirli süreli iş sözleşmesi yapılması için haklı neden oluşturacak olgulardır. $\mathrm{Bu}$ nedenle mesela, siparişlerin geçici bir dönem için olağan üstü biçimde artması, bir işçinin senelik izne ayrılması,

67 Mevsimlik işler, niteliği gereğince sadece belli mevsim veya yılın belli dönemlerinde yoğunluğu artan işlerdir. Bu nedenle mevsimlik işlerin aslında belirsiz süreli iş olduğu belirtilmiştir. Böylece, mevsim dışında iş sözleşmesinin askıda olduğu kabul edilmektedir. Ancak mevsimlik işlerin taraflara, belirli süreli iş sözleşmesi yapma hakk1 verdiği de doktrinde ileri sürülmüştür. Bkz. Çelik, s. 83; Süzek, İş Hukuku, s. 201; Tuncay, İş Sözleşmesi Türleri, s. 130; Ekonomi, Hukuka Uygunluk, s. 19; Taşkent, Savaş: "Belirli Süreli Hizmet Akdi ve Kıdem Tazminatına Hak Kazanma", [İHU, İşK 9 (No: 5)]; Ertürk, s. 231; Güler, Belirli Süreli, s. 43. Aksi yönde: Alpagut, 4857 Sayılı Yasa, s. 81. Karş. Alpagut, Belirli Süreli, s. 105 vd.. Ancak Yargıtay, mevsimlik iş sözleşmesinde, zincirleme sözleşmeler nedeniyle ilişkiyi belirsiz süreli iş sözleşmesi olarak nitelemiştir. Bkz. 9. HD, 28.01.1999, 4389/6715 sayılı kararı (Güler, Belirli Süreli, s. 43, dn. 31). Bu konuda bkz. aşa. III, B.

68 Çelik, s. 83; Eyrenci, Öner: "Hukuka Uygun Belirli Süreli Hizmet Akitlerinin Türleri”, Türk-İsviçre Hukukunda Belirli Süreli Hizmet Akitlerinin Hukuki Sorunları, Rehbinder/Ekonomi, İstanbul 1979, s. 70 (Belirli Süreli).

69 Süzek, İş Hukuku, s. 202; Güler, Belirli Süreli, s. 42.

70 Bkz. Süzek, İș Hukuku, s. 201; Eyrenci/Taşkent/Ulucan, s. 47; Güler, Belirli Süreli, s. 42.

71 Alpagut, 4857 Sayıl1 Yasa, s. 79. 
uzun bir hastalık nedeniyle istirahatlı olması, gebelik nedeniyle doğum iznine ayrılması ve işyerinde bu işçinin işini yapacak diğer bir işçinin bulunmaması gibi durumlar, belirli süreli iş sözleşmesi yapılması için ortaya çıkan ve objektif haklı neden oluşturan olgular olarak değerlendirilebilir ${ }^{72}$. Görüldüğü gibi ortaya çıkan bu olgular, geçici olmaları nedeniyle belirli süreli iş sözleşmesi yapılmasını haklı göstermektedir. Ancak, siparişlerin artması geçici değil de, sürekli bir nitelik taşıyorsa, artık belirli süreli iş sözleşmesi yapılmasını haklı gösteren objektif nedenlerin bulunduğu söylenemeyecektir ${ }^{73}$.

Ortaya çıkan olgu, işyerinden kaynaklanabileceği gibi -siparişlerin artması veya niteliksiz işçilerin eğitilmesi-, diğer işçilerden de -doğum izni gibi- kaynaklanabilir. Ayrıca, ortaya çıkan olgunun, asıl iş yanında yardımcı işlerde de ortaya çıkabileceği belirtilmiştir ${ }^{74}$. Mesela, olağanüstü bir sipariş artışında ek personele ihtiyaç duyulması durumunda asıl işte; aynı olayda işçilerin dişarıda yemek yemelerinin zaman kaybına neden olduğunun düşünülmesi durumunda, bu siparişin tamamlanacağ 1 süre için, işçilere iş yerinde yemek verilmesi için yeni işçilere ihtiyaç duymasında ise, yardımcı işte ortaya çıkan olgular söz konusu olur.

İş Kanunun 11. maddesinde, iş sözleşmesinin belirli süreli olabilmesi için gereken objektif nedenlerin sınırlı biçimde belirtilmediği, benzeri haklı nedenlerin de, belirli süreli iş sözleşmesi yapılabilmesi için geçerli olabileceği belirtilmesine rağmen, belirli bir olgunun ortaya çıkması şeklinde belirtilmiş bulunan kavram, gerçekte, başlı başına diğer bütün halleri de içine alabilecek torba bir hüküm niteliği taşımaktadır.

\section{d. Benzeri nedenler}

Yukarıdaki başlıkta da belirtildiği gibi, belirli bir olgunun ortaya çıkması kavramı bir torba hüküm olmasına rağmen, benzer haklı nedenlerin de belirli süreli iş sözleşmesi yapılabilmesi için objektif neden sayılacağı, İş Kanununun 11. maddesinde dolaylı da olsa belirtilmiştir. Bu hükümde geçen, “... gibi objektif koşullara bağlı olarak ...” şeklindeki ifade, objektif nedenlerin sınırlı olmadığını ortaya koymuştur ${ }^{75}$. Böylece kanun koyucu,

72 Bkz. ve karş. Süzek, İş Hukuku, s. 202; Alpagut, Belirli Süreli, s. 95 vd.; Alpagut, 4857 Sayılı Yasa, s .79; Güler, Belirli Süreli, s. 42.

73 Alpagut, 4857 Sayılı Yasa, s. 80; Güler, Belirli Süreli, s. 44.

74 Örnekler için bkz. Güler, Belirli Süreli, s. 44.

75 Objektif nedenlerin, kişisel nedenlerden, yapılan işin özelliklerinden, işletmenin gereklerinden veya yasal zorunluluklardan doğabileceği ileri sürülmüştür. Bkz. Alpagut, Belirli Süreli, s. 74 vd. 
benzer haklı nedenlerin ${ }^{76}$ de belirli süreli iş sözleşmesi yapılmasına olanak sağlayacağını hüküm altına almıştır ${ }^{77}$.

Mevsimlik işler, hastaya bakma, profesyonel futbolcular ve sanatçılarla yapılan iş sözleşmeleri, belirli süreli iş sözleşmesi yapılması için diğer objektif nedenler arasında sayılabilir ${ }^{78}$.

Kanundan doğan belirli süreli iş sözleşmesi yapma zorunluluğuna ilişkin hükümler de bu başlık altında incelenmelidir. Mesela, 625 sayılı Özel Okul Öğretmenleri Hakkında Kanun gereğince, özel okul öğretmenleriyle yapılacak iş sözleşmeleri en az bir yıl süreli olmak kaydıyla belirli süreli olarak yapılır. Böylece iş sözleşmesinin özel okul öğretmeniyle yapılacak olması, bu sözleşmenin yasa hükmü gereğince belirli süreli sözleşme biçiminde yapılmasını zorunlu kılmaktadır ${ }^{79}$. Bu durum, bu tür belirli süreli iş sözleşmelerinin hem yapılmasında, hem de tekrarlanmasında objektif neden sayılacak ve zincirleme olarak yapılan bu tür iş sözleşmelerinin belirsiz süreli sayılması mümkün olamayacaktır ${ }^{80}$.

Bunun gibi, ortak olmayan kişiler arasından atanan anonim şirket müdürünün en fazla üç yıl için atanabileceğini belirten TTK m. 314 ve 344 hükümleri de, belirli süreli iş sözleşmesi yapılması için objektif neden oluşturan diğer yasal hükümlerdendirr ${ }^{81}$.

Yargıtay kararlarıyla kabul edilmiş bulunan belirli süreli iş sözleşmesi yapılmasını haklı gösteren objektif neden olarak, yapılacak olan işin türü de gösterilebilir ${ }^{82}$. Buna göre bazı meslekler, belirli süreli iş sözleşmeleri için

76 Bunların tespitinde, işçi ile işverenin meşru menfaatlerinin dikkate alınmasının ve bunlar arasında adil bir denge gözetilmesinin gerekli olduğu doktrinde ileri sürülmüştür. Bkz. Alpagut, Belirli Süreli, s. 74, 75.

77 Süzek, İş Hukuku, s. 202; Alpagut, 4857 Sayılı Yasa, s. 81; Güler, Belirli Süreli, s. 45. Karş. Ekonomi, Hukuka Uygunluk, s. 18.

78 Süzek, İş Hukuku, s. 202; Ertürk, s. 235; Tuncay, İş Sözleşmesi Türleri, s. 130. Karş. Alpagut, 4857 Sayıl1 Yasa, s. 81, 82.

79 Doktrinde haklı olarak, iş güvencesi siteminin getirilmesinden sonra, 625 sayılı Kanuna göre çalışan işçilerin, bu sistemden hiçbir şekilde yararlanamamalarının uygun olmadığı, eğitimin aksamaması amacının, asgarî süreli iş sözleşmesiyle sağlanabileceği, bu nedenlerle 625 sayılı Kanundaki bu hükümlerin değiştirilmesinin yerinde olacağ sürülmüştür. Alpagut, 4857 Sayılı Yasa, s. 84; Eyrenci/Taşkent/Ulucan, s. 49.

80 Ekonomi, [İşK 9 (No: 4)]; Alpagut, 4857 Sayılı Yasa, s. 84. Yargitay 9. Hukuk Dairesinin 26.01.1993 tarih ve 1992/12253 E., 1993/949 K. sayılı kararından: “... Her ne kadar birbirini izleyen belirli süreli sözleşmeler akit yapma serbestisinin kötüye kullanımı nedeniyle başlangıçtan itibaren belirsiz süreli sözleșme olarak kabul edilmekte ise de, bu olayda taraflar arasında belirli süreli sözleşme yapılması 625 sayılı Yasa'da öngörülmüş bulunduğundan işverenin akit yapma serbestisini kötüye kullandiğl ileri sürülemez.” (Güler, Belirli Süreli, s. 46, dn. 36].

81 Çelik, s. 86; Süzek, İş Hukuku, s. 203.

82 Çelik, s. 86; Alpagut, Belirli Süreli, s. 88; Güler, Belirli Süreli, s. 47. 
objektif neden oluşturabilir. Mesela hemşirelik ${ }^{83}$ veya genel müdürlük ${ }^{84}$ bu tür mesleklerdendir. $\mathrm{Bu}$ görüşün dayanağı, yapılan işin nitelikli eleman ihtiyacı göstermesidir. Ancak doktrinde haklı olarak ileri sürüldüğü gibi, nitelikli elemanların yapacakları işlere ilişkin sözleşmelerin, diğer bir objektif neden bulunmadıkça, sırf işin nitelikli eleman gerektirmesi nedeniyle belirli süreli yapılması kabul edilemez ${ }^{85}$. Nasıl ki, Yargıtay'ın, niteliksiz işçiyle yapılan sözleşmenin belirli süreli olmayacağını kabul eden kararları yerinde görülmüyorsa, sırf işçinin nitelikli olmasının, objektif neden sayılması da aynı şekilde değerlendirilmelidir ${ }^{86}$. Bu nedenle objektif nedenin bulunduğundan söz edilebilmesi için, işin nitelikli işçi gerektirmesinden çok, işin niteliği gereği belirli süreli olmasının önem taşıması üzerinde durulmalıdır. Böylece, profesyonel futbolcular ve sanatçılarla yapılan iş sözleşmelerinin niteliği gereği belirli süreli olmaları nedeniyle, bunun objektif neden oluşturabileceği ileri sürülmüştür ${ }^{87}$.

Aynı şekilde, objektif diğer bir neden yoksa yurt dişına eğitim amacıyla gönderilen işçilerin geri döndüklerinde, belirli süreli iş sözleşmesiyle çalıştırılmak istenmesi yerinde olmayacaktır ${ }^{88}$. Çünkü işçinin nitelikli eleman olması ve eğitim için yurt dışına gönderilmiş bulunması, belirli süreli iş sözleșmesi yapılması için objektif nedenlerden değildir.

83 Bu yönde: Yargitay 9. HD, 09.05.2002, 2001/20847 E., 2002/7404 K. sayılı kararından: "Davall, davacıya ait işyerinde birbirini izleyen belirli süreli sözleşmelerle hemşire olarak çalışmaktadır. ... Hemşirelik işinin nitelikli olup olmadığ̆, sorunun çözümü bakımından önem taşımaktadır. ... Ülkemiz koşulları ve Anayasal sağlık hakkı dikkate alındı ̆̆ında hemşirelik görevinin yerine getirilmesi büyük önem taşır. Hastanelerimizin büyük hemşire açı̆̆ı olduğu ve bu açı̆̆ın bir türlü kapatılamadı̆̆g bilinen bir gerçektir. Bu itibarla hemşire ile hastane arasında düzenlenen sözleşmeler birbirini takip etse de, bunların her birinin belirli süreli nitelikte olduklarının kabulü zorunluluğu vardır." (Tekstil İşveren Dergisi, 2003/7, s. 37; ayrıca bkz. Güler, Objektif Neden, s. 545).

84 Nitekim Yargıtay, 1475 sayılı Kanun döneminde verdiği bir kararında, genel müdür ile yapılan iş sözleşmesinin, yapılan işin konumu ve niteliği gereğince, belirsiz süreli iş sözleşmesine dönüşmesinin mümkün olmadığına, bunun kaç kez yenilendiğinin bir önemi bulunmadığına karar vermiştir. Yargıtay 9. HD, 11.04.2003, 2002/20581 E., 2003/6120 K. sayılı kararı (Tekstil İşveren Dergisi, Ağustos 2003, S. 284, s. 34, ayrıca bkz. Çimento İşveren Dergisi, 2003/7, s. 52). Bu karardan: “...Belirli süreli iş sözleşmesinin belirsiz süreli iş sözleşmesine dönüşmesi için, birden çok kez yenilenmiş olması gerekir. Ancak, genel müdürün iş sözleşmesi; gerek kendisinin konumu ve gerekse işin niteliği karşısında, kaç kez yenilenmiş olursa olsun, belirsiz süreli iş sözleşmesine dönüşmez ve ihbar tazminatının ödenmesi gerekmez..."

85 Süzek, İş Hukuku, s. 203; Eyrenci/Taşkent/Ulucan, s. 48; Ulucan, İș Sözleşmesi Türleri, s. 44; Güler, Objektif Neden, s. 553. Aksi yönde: Centel, Tankut: "Belirli Süreli İş Sözleşmesinin Yenilenmesi (Karar İncelemesi)", Tekstil İşveren Dergisi, Ağustos 2003, S. 284, s. 35.

86 Karş. Tuncay, İş Sözleşmesi Türleri, s. 131.

87 Alpagut, Belirli Süreli, s. 88 vd.; Ertürk, s. 235; Eyrenci, Belirli Süreli, s. 67.

88 Bkz. Süzek, İş Hukuku, s. 203. 
İşveren bu tür işçisiyle asgarî süreli iş sözleşmesi yapmak suretiyle, ondan beklediği yararı kolaylıkla sağlayabilir.

İşverenin işçiyi tanımak istemesinin (deneme amact), belirli süreli iş sözleşmesi yapılmasını haklı kılan bir neden olup olmayacağı, İş Kanununun 15. maddesinin incelenmesinden sonra tespit edilmelidir. Bu hükme göre, iş sözleşmelerine konulacak deneme kaydı en çok iki ay olabilir; ancak bu süre toplu iş sözleşmesiyle dört aya kadar uzatılabilir. Bu süre içinde taraflar sözleşmeyi bildirimsiz, tazminatsız olarak feshedebilirler. $\mathrm{Bu}$ hüküm karşısında, deneme amacının objektif neden olup olmadığı, yapılan belirli süreli iş sözleşmesinin süresine göre tespit edilmelidir. Deneme amaçlı belirli süreli iş sözleşmesinin süresi, Kanunun 15. maddesinde belirtilen süreden fazla ise, bunun geçersiz olacağı kabul edilmelidir ${ }^{89}$. Çünkü İş Kanununun 15. maddesinde, deneme kaydına azamî bir sınır çizilmiştir. Bu sınırın deneme amacıyla yapılan belirli süreli iş sözleşmesiyle aşılması, Kanunun deneme süresine koyduğu azamî süreyi dolanma anlamına geleceği için, bu sınırı aşan deneme amaçlı belirli süreli iş sözleşmeleri belirsiz süreli sayılmalıdır ${ }^{90}$. Bunun dışında işveren, deneme amacını, İş Kanununun 15. maddesine uygun olarak yapacağı bir iş sözleşmesiyle de sağlayabilir. $\mathrm{Bu}$ nedenle deneme amac1, süresi 15 . maddede belirtilen süreden uzun olan belirli süreli iş sözleşmeleri için objektif neden sayılmamalıdır.

Deneme amacıyla yapılan belirli süreli iş sözleşmesinin süresi, Kanunun 15. maddesinde belirtilen azamî süreden az ise, deneme amacinın belirli süreli iş sözleşmesi için objektif neden oluşturup oluşturmayacağ 1 tartışmalı bir konudur. Doktrinde ileri sürülen bir görüşe göre, 15. maddede belirtilen süre kadar veya daha az süreli belirli süreli iş sözleşmelerinde deneme amacı objektif neden sayılmalıdır ${ }^{91}$. Karşı görüşe göre ise, deneme kaydının belirli süreli iş sözleşmelerine de konulabilmesi nedeniyle, deneme amacı belirli süreli iş sözleşmesini haklı kılan objektif bir neden olamaz ${ }^{92}$. $\mathrm{Bu}$ görüşe göre, deneme süresi içinde bildirimsiz ve tazminatsız fesih hakkı bulunduğu için, sırf bu amaçla ve deneme süresi boyunca belirli süreli iş sözleşmesi yapılmasına gerek bulunmamaktadır. Bu nedenle deneme süresi, belirli süreli iş sözleşmesi için haklı neden oluşturmaz.

89 Alpagut, 4857 Sayılı Yasa, s. 83; Alpagut, Belirli Süreli, s. 81; Eyrenci/Taşkent/Ulucan, s. 45; Güler, Belirli Süreli, s. 45; Mollamahmutoğlu, s. 15. 1475 sayılı İş Kanunu döneminde, deneme amaçlı belirli süreli iş sözleşmelerinin hukuka uygun olduğu ileri sürülmüştü. Bu yönde: Narmanlığlu, İş Hukuku, s. 184, dn. 152; Eyrenci, Belirli Süreli, s. 61; Ertürk, s. 234. İsviçre hukukundaki durum için bkz. Rehbinder, s. 42. 
Kanaatimce, 15. maddedeki süre içinde kalmak kaydıyla deneme amacıyla belirli süreli iş sözleşmesi yapılması objektif neden olarak değerlendirilmelidir. Çünkü deneme süresi içinde iş sözleşmesinin bildirimsiz ve tazminatsız feshi mümkün iken, deneme amaçlı belirli süreli iş sözleşmesinde, bu süre içinde bildirimsiz fesih mümkün değildir. Böylece, deneme amacıyla belirli süreli iş sözleşmesi yapılması, deneme kaydına oranla işçi yararına olacaktır. Bu nedenle, süresi 15. maddede belirtilenden az olan sözleşmelerde deneme amacının objektif neden oluşturabileceğinin kabulünde, hakkaniyete aykırı bir yön görülmemektedir ${ }^{93}$.

Ancak, burada belirtilmesi gereken konu, 15. maddedeki azamî süreyi aşan sözleşmelerde, işverenin deneme amacının tek başına belirli süreli iş sözleşmesi yapma hakkı vermeyeceğidir. Yoksa bunun dışındaki haklı nedenlerle yapılmış belirli süreli iş sözleşmesine deneme kaydının konulmasında hukuken bir engel bulunmamaktadır ${ }^{94}$.

İş sözleşmesine veya işyeri iç yönetmeliğine konulan ve işçinin belli bir yaşta veya emeklilik koşulların tamamlaması durumunda işten çıkarılacağının (sözleşmenin feshedileceğinin) kararlaştırıldığı durumların, konumuzla ilişkisi bulunmaktadır. Bu hükümlerin sözleşmeyi belirli süreli hale getirip getirmediklerinin incelenmesi gerekmektedir. Bu tür kayıtların getirilme nedenlerinin başında, genç iş gücüne duyulan ihtiyaç ve işçinin belirli bir yaşa gelmesi nedeniyle yeterlilik seviyesinin düşeceği endişesidir.

İşçinin yetersizliği, zaten fesih için bir geçerli neden olarak düzenlendiğinden dolayı, sırf iş̧̧inin belli bir yaşa gelmesinin tek başına objektif neden teşkil etmediği, çünkü ilerlemiş yaşın, yetersizlik sonucunu her zaman doğurmadığ ${ }_{1}$ doktrinde ileri sürülerek, bu tür kayıtların sözleşmeyi belirli veya azamî süreli hale getirmeyeceği belirtilmiştir ${ }^{95} . \mathrm{Bu}$ nedenle, bu tür kayıtlara rağmen iş sözleşmesi belirsiz süreli olma özellikleri koruyacaktır. Ancak, işçinin kararlaştırılmış bulunan yaşa gelmesi durumunda, iş sözleşmesinin işveren tarafindan feshi halinde, feshe bağlı sonuçlar da doğacaktır. Bu işçi iş güvencesi hükümlerinden yararlanamayan bir işçi ise ve fesih başkaca haklı nedenlere dayanmıyorsa, ki işçinin belli bir yaşa gelmesi tek başına haklı bir neden olamaz, işçi kıdem tazminatına hak kazanacaktır $^{96}$. İş güvencesine bağlı işçilerde ise, işçinin yetersizliği söz konusuyla, bu geçerli bir neden olmasına rağmen, haklı bir neden olmadığ 1 için, işçi kıdem tazminatına hak kazanır.

93 Bu yönde: Alpagut, 4857 Sayılı Yasa, s. 83; Şahlanan, Konferans Notları, s. 81.

94 Güler, Belirli Süreli, s. 45.

95 Bkz. ve karş. Rehbinder, s. 55; Alpagut, 4857 Sayılı Yasa, s. 83. Yazara göre, sözleşmenin sona ermesinin, işçinin belli bir yaşa gelmesine bağlanması bozucu koşuldur. Alpagut, Bozucu Şart, s. 414.

96 Bu yönde: Yargitay 9. HD, 30.06.1989, 5046/6188 sayılı kararı (YKD, 1990/2, s. 222). 
Sırf işçiye eğitim verilmiş olmasının, belirli süreli iş sözleşmesi yapılması için objektif neden oluşturmadığı kabul edilmelidir ${ }^{97}$. Çünkü işveren, sözleşmeye koyacağ 1 asgarî süre kaydıyla, yatırım yaptığ 1 işçisinin belli bir süre çalışmasını garanti altına alabilirr ${ }^{98}$.

\section{Belirli Süreli İş Sözleşmesi Kural Olarak Yazılı Şekilde} Yapılmalıdır

\section{Genel Olarak}

İş Kanununun 11. maddesinde, belirli süreli iş sözleşmesinin tanımı verilirken, belirli süreli iş sözleşmesinin yazılı yapılmasının gerekli olduğu belirtilmiştir. Böylece, süresi ne olursa olsun bütün belirli süreli iş sözleşmelerinin yazılı yapılmasının gerekli olduğu sonucu doğmaktadır ${ }^{99}$. Ancak, aynı Kanunun 8. maddesinde ise, belirli süresi bir y1l ve daha fazla olan iş sözleşmelerinin yazılı şekle bağlı oldukları belirtilmiştir. Bu nedenle, belirli süreli iş sözleşmesinin süresine göre bir ayrım yapılmasının gerekli olduğu, süresi bir yılın altında olan belirli süreli iş sözleşmelerinin yazılı şekle bağlı olmadıkları, ancak belirli süresi bir yıl ve daha fazla olan iş sözleşmelerinin ise, yazılı şekle bağlı oldukları kabul edilmelidir ${ }^{100}$.

\section{Yazılı Şeklin Hukukî Niteliği}

Süresi bir yıl ve daha fazla olan belirli süreli iş sözleşmelerinin bağlı tutulduğu bu yazılı şeklin, geçerlilik şekli mi, yoksa ispat şekli mi olduğu hususu doktrinde tartışmalıdır ${ }^{101}$. Doktrindeki hâkim görüşe göre, bu şekil ispat değil, geçerlilik şeklidir ${ }^{102}$. Çünkü hükümde kullanılan ifadelerin açıklığ 1 ve aranan şeklin ispat koşulu olduğu belirtilmediği için, BK. m.11/II gereğince bunun geçerlilik şekli olduğu kabul edilmelidir.

\section{Yazılı Şekilde Yapılması Gereken Belirli Süreli İş Sözleşmesinin} Bu Şekle Uyulmaksızın Yapılmasının Hukukî Sonucu

Genel olarak kabul edildiği üzere, kanunen geçerlilik şekline bağlı

97 Tuncay'a göre, meslekî eğitim verilmesi, Avrupa Birliğinin 1999/70 say1lı Yönergesinde objektif neden kabul edilmiştir. Tuncay, İş Sözleşmesi Türleri, s. 130. Ayrıca bkz. Ünal, s. 80 .

98 Alpagut, 4857 Sayılı Yasa, s. 84.

99 Çelik, s. 81; Tuncay, İş Sözleşmesi Türleri, s. 131; Güler, Belirli Süreli, s. 55.

100 Alpagut, 4857 Sayılı Yasa, s. 86; Tuncay, İş Sözleşmesi Türleri, s. 131; Çelik, s. 114. Aksi görüşteki Uçum'a göre, belirli süreli iş sözleşmesinin süresi ne olursa olsun, yazılı şeklide yapılması gerekir (Uçum, s. 34).

101 Bu konuda farklı bir görüş için bkz. Demir, s. 29.

102 Narmanlıoğlu, İş Hukuku, s. 154, 155; Tunçomağ, Kenan/Centel, Tankut: İş Hukukunun Esasları, İstanbul 2004, s. 80; Tuncay, İş Sözleşmesi Türleri, s. 126, 131; Güler, Belirli Süreli İş Sözleşmesi, s. 55; Mollamahmutoğlu, s. 8. İspat koşulu olduğu yönünde: Eyrenci/Taşkent/Ulucan, s. 51; Demir, s. 24; Alpagut, Belirli Süreli, s. 23; Alpagut, 4857 Sayılı Yasa, s. 86; Eyrenci, Genel Değerlendirme, s. 26. 
tutulan bir sözleşme, bu şekle bürünmeden yapılacak olursa geçerli olmaz, butlan yaptırımına tabi tutulur. Butlan yaptırımına bağlı bir sözleşme de, kural olarak baştan itibaren hiçbir hüküm ve sonuç doğurmaz. Ancak, gerek iş hukukunun niteliği, gerekse de iş sözleşmesinin sürekli borç ilişkisi doğurması nedeniyle geçersizliğin geçmişe götürülmesinin olanaksı olması dikkate alınarak, geçersizliğin geriye yürütülemeyeceği kabul edilmektedir. Nitekim Türk Borçlar Kanununu Tasarısının 398. maddesinin üçüncü fikrasına göre, "geçersizliği sonradan anlaşılan hizmet sözleşmesi, hizmet ilişkisi ortadan kaldırılıncaya kadar geçerli bir hizmet sözleşmesinin bütün hüküm ve sonuçlarını doğurur." Görüldüğü gibi, iş hukukunda kabul edilen bu ilke, Borçlar Kanunu Tasarısıyla açık bir hüküm olarak kabul edilmek istenmektedir.

Böylece, yazılı şekilde yapılmamış bulunan belirli süreli iş sözleşmelerinin ileriye etkili olarak geçersiz oldukları kabul edilmektedir ${ }^{103}$.

Geçerlilik şekline bağlı bir hukukî işlemin bu şekle uyulmadan yapılması durumunda uygulanacak yaptırımın geçersizlik olacağı her ne kadar kabul edilse de, süresi bir yıl veya daha fazla olan belirli süreli iş sözleşmelerinin yazılı şekilde yapılmaması durumunda bu sözleşmelerin geçersiz sayılmaması gerektiği, bunların belirsiz süreli iş sözleşmesi sayılması yoluyla ayakta tutulmasının yerinde olacağ 1 doktrinde ifade edilmiştir $^{104}$. Bu görüşü savunan Güler'e göre ${ }^{105}$, belirli süresi bir yıl veya daha fazla olan belirli süreli iş sözleşmelerinin yazılı geçerlilik şekline bağlı tutulmaları, sözleşmenin süresindeki belirliliğe ilişkindir. Bu belirlilik de yazılı sözleşmeyle sağlanacaktır. Bu nedenle, yazılı biçimde yapılmadığ için belirliliği bulunmayan iş sözleşmeleri daima belirsiz süreli iş sözleşmesi sayılmalıdır ${ }^{106}$.

Kanaatimce, belirli süresi en az bir yıl olan iş sözleşmelerinin yazılı biçimde yapılmaması durumunda, bu sözleşmenin ne baştan itibaren, ne de ileriye dönük olarak geçersiz olduğu kabul edilmelidir. Böylece, yazılı biçimde yapılmamış bulunan bütün iş sözleşmelerinin belirsiz süreli olduğu sonucuna varılması, gerek İş Kanununun 11. maddesinin emredici niteliğine, gerekse de iş hukukunun işçiyi koruyucu özelliğine uygun bir yorum olacaktır. Nitekim şekil koşuluna uyulmaması durumunda uygulanacak olan geçersizlik yaptırımının etkilerinin azaltılması için kabul edilmiş bulunan

103 Tunçomağ/Centel, s. 80; Tuncay, İş Sözleşmesi Türleri, s. 126. Bu sonucun, işçinin aleyhine olacağı yönünde: Eyrenci/Taşkent/Ulucan, s. 51.

104 Güler, Belirli Süreli, s. 56.

105 Güler, Belirli Süreli, s. 56.

106 Alpagut aynı sonuca, yazılı şekle ilişkin koşulun, ispat koşulu olduğunu ileri sürerek varmaktadır (Alpagut, 4857 Sayılı Yasa, s. 86, 87). 
tahvil kurumu gereğince de aynı sonuca varılabilir ${ }^{107}$. Buna göre, kanunda aranan şekil koşuluna uyulmaksızın yapıldığı için geçersiz olan bir sözleşme (belirli süreli iş sözleşmesi) yerine, bu sözleşmenin gerçekleştirmek istediği amacı veya doğurmak istediği hukukî sonucu başka bir sözleşme (belirsiz süreli iş sözleşmesi) doğurabilecek durumda ise ve mevcut şekil, ilgili sözleşme için aranan şekil koşulunu da karşılıyorsa, tarafların farazi iradelerinin de bu yönde bulunması kaydıyla, geçersiz sözleşme, kanunî şekle sahip diğer sözleşme olarak ayakta tutulabilirr ${ }^{108}$. Böylece, kanunen aranan yazılı geçerlilik koşulunun bulunmaması durumunda, taraflar arasındaki iş sözleşmesinin belirsiz süreli iş sözleşmesi olarak geçerli olduğunun kabul edilmesinde, kanaatimce hakkaniyete aykırı bir yön bulunmamaktadir ${ }^{109}$.

\section{OBJEKTIF BİR NEDEN BULUNMAKSIZIN YAPILAN BELİRLİ SÜRELİ İŞ SÖZLEŞMELERINIIN HUKUKİ DURUMU}

4857 sayılı İş Kanunundan önceki dönemde, belirli süreli iş sözleşmesi yapma hakkının kötüye kullanılmasının yaptırımı mevzuatımızda açıkça yer almıyordu. Bu dönemde Yargıtay kararlarıyla getirilen ilkelere göre, belirli süreli iş sözleşmelerinin bazı durumlarda belirsiz süreli iş sözleşmesine dönüşeceği kabul ediliyordu. $\mathrm{Bu}$ durum da daha çok, zincirleme yapılan iş sözleşmelerinde gündeme geliyordu ${ }^{110}$. Ancak, Yargıtay'ın bu kararları, işverenin belirli süreli iş sözleşmesi yapma hakkını kötüye kullandığı ve bunun kanıtlanabildiği durumlara ilişkindir. Diğer bir ifadeyle, zincirleme iş sözleşmelerinin baştan itibaren belirsiz süreli iş sözleşmesi sayılması için, işverenin sözleşme yapma özgürlüğünü kötüye kullanması, işçiyi işçilik haklarından mahrum bırakması gerekiyordu ${ }^{111}$.

Ancak 4857 sayılı Kanun ile işverenin hakkını kötüye kullanması aranmadığ gibi, belirli süreli iş sözleşmesinin bir unsuru olarak objektif

107 Karş. Narmanlıŏglu, İş Hukuku, s. 155; Demir, s. 24.

108 Kaneti, Selim: Hukuki İşlemlerin Çevrilmesi, İstanbul 1972, s. 1 vd.; Esener, Turhan: "Hukuki Muamelelerde Tahvil", AÜHFD, 1959/1-4, s. 234 vd.

109 Tuncay'a (İș Sözleşmesi Türleri, s. 128) göre, Fransız İs Kanununda da, yazılı sözleşme yapılmayan hallerde iş sözleşmesinin belirsiz süreli olduğu kabul edilmiştir. Bu konuda ayrica bkz. Alpagut, 4857 Sayılı Yasa, s. 86, dn. 42.

110 Çelik, s. 84; Süzek, İş Hukuku, s. 204; Ekonomi, Hukuka Uygunluk, s. 15; Ekonomi, [İşK 9 (No: 4)]; Narmanlıŏlu, Ünal: “Aralıklarla Kurulmuş İş Sözleşmeleriyle Çalışan İşçinin Kıdem/Hizmet Süresinin Belirlenmesine İlişkin Kanuni Esaslar ve Yargıtayın Tutumu”, Prof. Dr. Halid Kemal Elbir'e Armağan, İstanbul 1996, s. 318 (Aralıklarla Kurulmuş İş Sözleşmesi); Sur, s. 273; Güler, Belirli Süreli, s. 47; Eyrenci, Belirli Süreli, s. 58.

111 YHGK, 06.04.1994 tarih ve 50/210 say1l kararından: “...ortada objektif haklı bir neden olmadıkça, işçinin zincirleme sözleşmelerle çalıştırılması ve böylece belirsiz süreli iş sözleşmelerine tanınan koruyucu hükümlerden kurtulmak amacının güdülmesi akit serbestisinin kötüye kullanılması halini oluşturur..." (Güler, Belirli Süreli, s. 49, dn. 43). 
nedenlerin varlığı gerektiği için, objektif nedenlerin bulunmamas1, sözleşmenin belirsiz süreli iş sözleşmesi sayılması için yeterli sayılmıştır ${ }^{112}$.

\section{A. İlk Kez Yapılan İş Sözleşmelerinin Belirsiz Süreli İş Sözleşmesi Sayılması}

1475 sayılı Kanun döneminde doktrinde, belirli süreli iş sözleşmesinin, ilk kez yapıldığı dönemde de belirsiz süreli sayılabilmesinin mümkün olduğu savunulmuş ${ }^{113}$, ancak bunun için işverenin, işçiyi bazı işçilik haklarından mahrum bırakmak şeklinde kötüniyetli bir davranışının bulunması gerektiği ileri sürülmüştü ${ }^{14}$. Benzer görüşler bazı Yargıtay kararlarında da benimsenerek, özellikle niteliksiz işçilerin belirli süreli iş sözleşmesiyle çalıştırılmalarının dürüstlük kurallarına aykırı olması nedeniyle, bu iş sözleşmeleri belirsiz süreli sayılmıştı ${ }^{115}$.

Ancak 4857 sayılı Kanun ile belirli süreli iş sözleşmesi yapılması için, bunu haklı gösteren objektif nedenlerin varlığı arandığından dolayı, bu nedenler bulunmadan yapılan iş sözleşmeleri, daha başından itibaren belirsiz süreli sayıldığ 1 için, işverenin kötüniyetine gerek yoktur ${ }^{116}$. Böylece, işverenin iş sözleşmesinin ilk yapıldığı andaki kötüniyetinin kanıtlanmasına gerek kalmamıştır. Çünkü objektif nedenlerin yokluğu, iş sözleşmesini doğrudan belirsiz süreli hale getirmektedir.

Ancak bu şekilde baştan itibaren belirsiz süreli olduğunu kabul ettiğimiz iş sözleşmesinde, fesih hakkının belli bir süre sınırlandığı da kabul edilmelidir. Diğer bir ifadeyle, objektif neden bulunmamasına rağmen belirli süreye bağlanan iş sözleşmeleri, asgarî süreli iş sözleşmesi sayılmalıdır.

112 Güler, Belirli Süreli, s. 47.

113 Karş. Ekonomi, Hukuka Uygunluk, s. 16; Ekonomi, [İşK 9 (No: 4)]; Sur, s. 275; Ertürk, s. 246; Alpagut, Değerlendirme, s. 94.

114 Bkz. ve karş. Narmanlıoğlu, İş Hukuku, s. 182; Çelik, s. 84, 85; Şahlanan, Konferans Notları, s. 80; Güler, Belirli Süreli, s. 40; Ekmekçi, s. 73.

115 Yargıtay, bu yöndeki kararlarının bazılarında, sadece yapılan işin niteliğine bakarak, işin nitelikli işçi gerektirmemesi nedeniyle başkaca bir gerekçe göstermeksizin sözleşmenin belirsiz süreli sayılacağına hükmetmiştir. Bu yöndeki Yargıtay 9. Hukuk Dairesinin 24.10.1991 tarih ve 8961/13488 sayıll kakarından: “... bir inşaat işinde çalıştırılmak üzere işe alınan işçi yönünden aradaki hizmet sözleşmesinin, belirsiz süreli hizmet sözleșmesi niteliğinde olduğunun kabul edilmesi gerekir..." (Güler, Belirli Süreli, s. 33, dn. 7). Ancak diğer bazı kararlarında ise, işverenin iş̧̧iyi, bazı işçilik haklarından mahrum bırakmak şeklindeki kötüniyetli davranışını aramıştır. Bu yöndeki Yargıtay 9. Hukuk Dairesinin 10.04.1995 tarih ve 11476/12308 say1lı kararından: “... taraflar arasında bağıtlanan hizmet akdinin içeriğine ve yapılan işin niteliğine göre sözleşmenin belirsiz süreli hizmet akti olduğunun kabulü gerekir. ... Bu nedenle, işverenin yasanın belirsiz süreli hizmet akitlerine tanıdiğı haklardan kaçınmak için yaptığı sözleşme görünüşte belirli süreli olup, yapılan iş özelliği ve niteliği itibariyle gerçekte belirsiz süreli bir sözleşmedir." (Güler, Belirli Süreli, s. 40, dn. 25).

116 Bkz. Süzek, İş Hukuku, s. 199; Güler, Belirli Süreli, s. 48. 
Çünkü belirli süreli iş sözleşmesinde önemli olan nokta, belirli sürenin sonunda iş sözleşmesinin kendiliğinden sona ermesini sağlamak olduğu için, objektif neden bulunmamasına rağmen belirli süreye bağlanan iş sözleşmelerinde bu amaca engel olunmasıly yetinilmesi kanaatimce işçinin korunması bakımından yerinde olur. Objektif neden bulunmamasına rağmen belirli bir süreye bağlanmış iş sözleşmelerinin baştan itibaren belirsiz süreli sayılması gerekmekle birlikte, taraflarca belirlenmiş süre içinde bildirimli fesih hakkının bulunmadığ 1 da kabul edilmelidir. Bu yorum, hem işçinin korunması ilkesine, hem de, tarafların iradelerine uygun olacaktır. Çünkü işveren, iş sözleşmesini belirli bir süreye bağlamakla, bu süre içinde bildirimli fesih hakkı bulunmadığını kabul etmiş iken, objektif nedenlerin bulunmaması nedeniyle bu sözleşme normal bir belirsiz süreli iş sözleşmesi sayılırsa, işverenin bu süre içinde bile bildirimli fesih hakkının bulunduğu sonucu ortaya çıkacaktır. Bu durum ise kuşkusuz ki işçinin aleyhine olur. $\mathrm{Bu}$ nedenlerle, objektif neden bulunmamasına rağmen iş sözleşmesinin taraflarca belli bir süreye bağlanması durumunda, baştan itibaren belirsiz süreli sayılan bu iş sözleşmesinde, bildirimli fesih hakkının taraflarca belirlenen süreyle sınırlı olarak ortadan kaldırıldığı kabul edilmelidir.

Üzerinde düşünülmesi gereken bir husus, var olan bir objektif nedenin süresini aşar biçimde belirli süreli iş sözleşmesi yapılması durumunda doğacak sonuçlardır. Mesela, yapılacak olan iş, altı ay devam edecek olmasına rağmen, 7 aylık veya 10 aylık belirli süreli iş sözleşmesi yapılması durumunda, sözleşmenin geçerli olup olmayacağı, daha doğrusu, belirli süreli olma özelliğini taşıyıp taşımayacağı konusu önemlidir.

Doktrinde Güler tarafından bu durum değerlendirilmiş ve objektif nedenin gerektirdiği sürenin aş1larak belirli süreli iş sözleşmesi yapılması durumunda, aşkın sürenin niteliğine ve somut olayın özelliklerine bakılması gerektiği ileri sürülmüştür ${ }^{117}$. Yazara göre, objektif nedenin gerektirdiği sürenin açıkça ve dikkat çekici biçimde aşılması durumunda, bu aşkınlığı hakl1 gösteren bir neden de bulunmuyorsa, sözleşmenin baştan itibaren belirsiz süreli sayılması gerekir. Ancak, objektif nedenin gerektirdiği sürenin aşılarak belirli süreli iş sözleşmesi yapılmasında, işin olası uzama ihtimali gibi bir neden dikkate alınmışsa ve aşkın süre de bu ihtimale uygun, makul bir süre ise, sözleşmenin belirli süreli olma özelliğini taşıdığı kabul edilmelidir. Yazar bunların yananda, tüm durumları kapsar bir ölçünün verilmesinin mümkün olmadığını, bu nedenle somut olayın özellikleri dikkate alınarak objektif nedenin gerektirdiği süreyi aşan bir belirlemeyi haklı gösteren nedenlerin bulunması durumunda, sözleşmenin belirli süreli olma özelliğini koruyacağını ileri sürmüştür. Kanaatimce, yazarın

117 Güler, Belirli Süreli, s. 48. 
gerekçelerinin ve vardığı sonucun İş Kanununun 11. maddesine uygun olduğunun kabul edilmesi gerekmektedir.

\section{B. Zincirleme İş Sözleşmelerinin Belirsiz Süreli İş Sözleşmesi Sayılması}

Zincirleme iş sözleşmesi, belirli süreli iş sözleşmelerinin birbiri ardına yapilmasidir ${ }^{118}$.

Belirli süreli iş sözleşmelerinin zincirleme sözleşme niteliği taşıyabilmesi için, birbiri ardına yapılmış en az üç iş sözleşmesinin varlı̆̆ 1 Yargıtay tarafından aranmaktadır ${ }^{119}$. Ancak, 4857 sayılı İş Kanununun 11. maddesinin ikinci fikrasında yer alan, "belirli süreli işs sözleşmesi, esaslı bir neden olmadikça, birden fazla üst üste (zincirleme) yapılamaz" hükmü gereğince, zincirleme sözleşmenin varlığı için, iş sözleşmesinin bir kez yenilenmiş olması da yeterli sayılmıştır ${ }^{120}$. Böylece, belirli süreli ilk iş sözleşmesinin ardından ikinci kez yapılan belirli süreli iş sözleşmesiyle, zincirleme sözleşme gerçekleşmiş olur ${ }^{121}$.

4857 sayılı Kanun değişikliği öncesinde, belirli süreli iş sözleşmesinin belirsiz süreli iş sözleşmesine dönüşmesi, çoğunlukla zincirleme olarak yapılan iş sözleşmelerinde söz konusu oluyordu ${ }^{122}$. Ancak, yukarıda da belirtildiği gibi yeni Kanun, ilk sözleşmede dahi objektif nedenlerin varlığını aradığı için, zincirleme sözleşmelerin, bütün halinde belirsiz süreli

118 Zincirleme iş sözleşmesinin varlığından bahsedilebilmesi için, iş sözleşmeleri arasına zaman girmemesi gerektiği 1475 sayılı İş Kanunu döneminde savunulmuştur. Narmanlıoğlu, Aralıklarla Kurulmuş İş Sözleşmesi, s. 319. Mevsimlik işler için farklı yönde: Alpagut, Belirli Süreli, s. 58; Alpagut, Değerlendirme, s. 92; Sur, s. 274. Ancak, 4857 sayılı İş Kanunu, ilk sözleşmenin yapılmasında da objektif nedenlerin varlığını aradığı için, sözleşmenin belirli - belirsiz süreli olup olmaması bakımından, bu hususun bir önemi kalmamıştır.

119 Yargitay 9. HD, 11.04.2003 tarih ve 2002/20581 E., 2003/6120 K. say1lı kararından: “... Belirli süreli iş sözleşmesinin belirsiz süreli hale dönüşebilmesi için, Dairemizin yerleşik içtihatlarında da olduğu gibi, birden çok kez yenilenmiş olması gerekir ..." (Tekstil İşveren Dergisi, 2003/8, s. 34; ayrıca bkz. Çimento İşveren Dergisi, 2003/7, s. 52, 53); Yargıtay Nöbetçi Hukuk Dairesinin 05.08.1981 tarih ve 6732/9529 sayılı kararında da, zincirleme sözleşmeden bahsedilebilmesi için, iş sözleşmesinin en az iki kez yenilenmiş olması aranmıştır (bu karar için bkz. Güler, Belirli Süreli, s. 50, dn. 44). Bu yönde bkz. 9. HD, 29.01.2004 tarih ve 2003/12091 E., 2004/1480 K. sayılı kararı (Legal İş Hukuku ve Sosyal Güvenlik Hukuku Dergisi, 2004/3, s. 1054); 9. HD, 27.02.2003 tarih ve 1523/2559 sayılı kararından: “... Dairemizin yerleşik içtihadına göre, belirli süreli hizmet sözleşmesi bir kez yenilenmekle niteliğini kaybetmez ..." (Bu karar eHukukRehberi bilgi arşivinden alınmıştır).

120 Çelik, s. 84; Süzek, İş Hukuku, s. 205; Güler, Belirli Süreli, s. 50. Ancak bu hüküm, eski uygulamayı çağrıştırması nedeniyle doktrinde eleştirilmiştir. Bkz. Ekmekçi s. 74; Karş. Tuncay, İş Sözleşmesi Türleri, s. 129, 130.

121 Karş. Alpagut, Belirli Süreli, s. 60.

122 Ertürk, s. 240; Alpagut, Belirli Süreli, s. 57. 
sayılacağına ilişkin bu hüküm eski önemini kaybetmiştir ${ }^{123}$. Çünkü ilk belirli süreli iş sözleşmesi için objektif neden zaten yoksa bu sözleşme baştan itibaren belirsiz süreli sayılacaktır. Hatta doktrinde, zincirleme sözleşmelere ilişkin hükmün, 11. maddenin birinci fikrası karşısında gereksiz olduğu bile ileri sürülmüştür ${ }^{124}$.

Objektif neden bulunması durumunda, yapılan bütün belirli süreli iş sözleşmeleri belirli süreli olma özelliklerini korurlar (İşK m. 11/III). Bunun için, objektif nedenlerin aynı olması gerekmez. Mesela, ilk sözleşmedeki objektif neden, bir işçinin doğum iznine ayrılmış bulunması iken, ikinci sözleşmedeki siparişin artması olabilir ${ }^{125}$.

Objektif nedenlerin bulunması durumunda, belirli süreli iș sözleşmesi 5 hatta $10 \mathrm{kez}$ bile yenilenebilecektir. Doktrinde Alpagut, belirli süreli iş sözleşmelerine süre bakımından bir sınır getirilmemiş olmasının uygulamada sorun yaratacağına dikkat çekmiştir ${ }^{126}$. Yazara göre, işverenin geçici bir siparişin sürekli olarak yenilenmesini bahane göstererek, işçiyle belirli süreli iş sözleşmeleri yapması, hakkaniyete aykırı sonuçlar doğuracaktır. Bu durumda yazar, belirli süreli iş sözleşmesi için objektif neden olan işin geçiciliğinin kaybolmuş bulunması nedenine dayanarak, somut olaydaki iş sözleşmesinin baştan itibaren belirsiz süreli sayllabileceğini haklı olarak ileri sürmüştür. Nitekim yazar bunu, şu ifadelerle ${ }^{127}$ belirtmiştir: “... somut olayda artık işçinin işletmenin sürekli işgücü ihtiyacını karşıladığının açık olduğu durumlarda yargı kararı ile sözleşme baştan itibaren belirsiz süreli kabul edilmek gerekir."

Belirli süreli iş sözleşmesi yapılabilmesi için gereken objektif neden, ilk sözleşmenin yapıldığı tarihte bulunmasına rağmen ikinci veya daha sonraki sözleşmelerin yapılması sırasında ortadan kalkmışsa, bu durumda iş ilişkisinin, objektif neden bulunmamasına rağmen belirli süreli olarak yapılan sözleşme tarihinden itibaren belirsiz süreli sözleşmeye dayandığının kabulü uygun olacaktır ${ }^{128}$.

Zincirleme iş sözleşmeleri için Kanunda kabul edilmiş bulunan sonucun -baştan itibaren belirsiz süreli sayılma-, belirli süreli iş sözleşmesinin süresinin, sözleşmenin sona ermesinden önce yapılacak bir

123 Alpagut, 4857 Sayılı Yasa, s. 85; Güler, Belirli Süreli, s. 50. Karş. Süzek, İş Hukuku, s. 206; Eyrenci/Taşkent/Ulucan, s. 50.

124 Alpagut, 4857 Sayılı Yasa, s. 85. Karş. Ulucan, İş Sözleşmesi Türleri, s. 46.

125 Güler, Belirli Süreli, s. 52-53; Alpagut, 4857 Sayılı Yasa, s. 85.

126 Alpagut, 4857 Sayılı Yasa, s. 86.

127 Alpagut, 4857 Sayılı Yasa, s. 86; Güler (Belirli Süreli, s.51), Alpagut'un endişesine katılmamakla birlikte, adı geçen yazarla aynı sonuca varmaktadır.

128 Güler, Belirli Süreli, s. 52. Alpagut ise, bu durumda iș ilişkisinin baștan itibaren belirsiz süreli sayılacağını savunmuştur (4857 Sayılı Yasa, s. 85). 
değișiklik anlaşmasıyla uzatılmasında da geçerli olacağ sürülmüştür ${ }^{129}$. Buna göre, sürenin sona ermesinden önce yapılacak bir değişiklik anlaşmasıyla sözleşmenin süresinin uzatılabilmesi için objektif nedenler aranmalıdır, aksi halde sözleşme baştan itibaren belirsiz süreli iş sözleşmesi sayılacaktır.

İşin mevsimlik olmasının, belirli süreli iş sözleşmesi yapılabilmesi için objektif bir neden olabileceği kabul edildiği için, üst üste yapılan bu tür çalışmaların zincirleme sözleşme niteliğinde olmayacağı, bunların her birinin bağımsız belirli süreli sözleşmeler olduğu kabul edilmelidir. Nitekim Yargitay 9. Hukuk Dairesinin 22.02.2001 tarih ve 2000/18588 Esas, $2001 / 2147 \mathrm{Karar}^{130}$ sayılı kararında, üç yıl ardı ardına yapılan mevsimlik işle ilgili belirli süreli iş sözleşmesinin, sürenin sonunda kendiliğinden sona ereceği için, işçinin kıdem tazminatı isteyemeyeceği belirtilmiştir ${ }^{131}$. Ancak aynı Daire, 13.11.2002 tarih ve 28341/21255 sayılı kararında ${ }^{132}$, bu görüşten ayrılarak, her yıl 6-8 ay yapılan mevsimlik işlerin belirli süreli iş̧ sözleşmesine dayansa bile, bunların belirsiz süreli sayılması gerektiğini belirtmiştir.

\section{IŞSERENIN, BELIRLI VE BELİRSIZ SÜRELI İŞ SÖZLEŞMELERINE DAYANARAK ÇALIŞAN IŞÇILER ARASINDA AYRIM YAPMA YASAĞI}

\section{A. Genel Olarak}

"Belirli ve Belirsiz Süreli İs Sözleşmesi Ayrımının Sınırları" kenar başlıklı İş Kanununun 12. maddesinin birinci fikrasına göre, belirli süreli iş sözleşmesiyle çalışan işçiler, haklı nedenler bulunmadıkça, sırf iş sözleşmesinin belirli süreli olması nedeniyle, belirsiz süreli iş sözleşmesiyle çalışan emsal işçiye göre farklı muameleye tâbi tutulamaz.

Görüldüğü gibi Kanunun 12. maddesi, işçilerin çalıştıkları iş sözleşmelerinin türüne göre, haklı nedenler bulunmaksızın farklı muamelelere tâbi tutulmalarını yasaklamıştır. Bu hükümle, işçiler arasında ayrım yapılabileceği, ancak bunun haklı nedenlerinin bulunmasının gerektiği de ortaya konulmuştur. Böylece mutlak bir eşitlik anlayışı tercih edilmemiştir. $\mathrm{Bu}$ ayrım yasağ 1 gereğince, işveren; belirli süreli iş sözleşmesiyle çalışan işçileri, aynı veya benzer işte belirsiz süreli iş sözleşmesiyle çalışan işçiye göre daha ağır işlerde çalıştıramayacak, onlara daha az ücret veremeyecek, sadece onlardan fazla çalışmada bulunmalarını isteyemeyecek veya onları iş güvenliği bakımından daha düşük konumlarda çalıştıramayacaktır ${ }^{133}$.

\footnotetext{
129 Alpagut, 4857 Sayılı Yasa, s. 85; Güler, Belirli Süreli, s. 51.

130 İşveren Dergisi, 2001/5, s. 17, 18.

131 Bu kararın yerinde olduğu hakkında bkz. Çelik, s. 273.

132 TÜHİS, 2003/Mayıs - Ağustos, s. 86, 90.

133 Süzek, İş Hukuku, s. 206; Eyrenci/Taşkent/Ulucan, s. 52; Alpagut, 4857 Sayılı Yasa, s. 87; Güler, Belirli Süreli, s. 57; Demir, s. 31.
} 
Ayrım yasağının sınırlarına yer veren maddenin ikinci fikrasında, belirli bir zaman ölçüt alınarak ödenecek ücret ve paraya ilişkin bölünebilir menfaatlerin, belirli süreli iş sözleşmesiyle çalışan işçiye, işçinin çalıştığı süreye orantılı olarak verileceği belirtilmiştir. Buna göre, belirli süreli iş sözleşmesiyle çalışan işçi, ödenecek olan ikramiyeden çalıştığı süreyle orantılı olarak yararlanacaktır ${ }^{134}$. Ancak bunun için, paraya ilişkin menfaatin bölünebilir olması gerekir. Bölünemez menfaatlerden, sadece o sıradaki mevcut işçiler yararlanır. Ancak bu durumda da işçiler arasında ayrım yasağı bulunmaktadır. Mesela, şirketin kuruluş yıldönümü nedeniyle işçilere verilen hediyelerden veya yardımlardan, aynı koşullardaki bütün işçilerin eşit biçimde yararlandırılmaları gerekir.

Ayrıca Kanunda, işçilerin kıdem sürelerinin hesabında, işçilerin çalıştıkları iş sözleşmelerinin türünün önemli olmadığı, haklı nedenler bulunmadıkça, belirli süreli iş sözleşmesiyle çalışan işçiye, belirsiz süreli iş sözleşmesiyle çalışan emsal işçi için esas alınan kıdemin uygulanacağ 1 da belirtilmiştir. Buna göre mesela, iki yıllık kıdemi bulunan işçilere sağlanan üç günlük ek yıllık iznin, hem belirsiz süreli, hem de belirli süreli iş sözleşmesiyle çalışan ve iki y1llık kıdemi bulunan bütün işçilere aynı biçimde uygulanması gerekmektedir ${ }^{135}$.

\section{B. Emsal İşçi Kavramı}

İş Kanununun 12. maddesinde, haklı nedenler bulunmadıkça, belirli süreli iş sözleşmesiyle çalışan işçi ile emsal işçi arasında farklı muamelede bulunulamayacağı düzenlenmiştir. Böylece haklı neden esası yanında, emsal işçi esası da getirilmiştir. Buna göre, belirli süreli iş sözleşmesiyle çalışan işçiye uygulanan muamele, ancak emsal işçiye uygulanmışsa eşit davranma ilkesine aykırılık söz konusu olmayacaktır. Böylece eşitlik ilkesinin mutlak bir anlama sahip olmadığı da vurgulanmıştır.

Emsal işçi, 12. maddenin son fikrasına göre, "işyerinde aynı veya benzeri işte belirsiz süreli iş sözleşmesiyle çalıştırlan iş̧̧idir. İşyerinde böyle bir işçi bulunmadığı taktirde, o işkolunda şartlara uygun bir işyerinde aynı veya benzeri işi üstlenen belirsiz süreli iş sözleşmesiyle çalıştırılan işçi dikkate alınır." Böylece emsal iş̧̧i, eşit işlem görüp görmediği değerlendirilen işçiyle denk tecrübesi, eğitimi ve yeterliliği bulunan ve önem taşıyacaksa aynı cinsiyetten olan, onunla aynı veya benzer işleri yapan ve belirsiz süreli iş sözleşmesiyle çalışan işçidir.

\section{Yasağa Aykırı Davranışın Yaptırımı}

İş Kanununun 12. maddesinde, yukarıda belirtilen ayrım yasağına aykırı davranışın yaptırımı düzenlenmemiştir. Ancak genel olarak işçiler

134 Süzek, İş Hukuku, s. 207; Güler, Belirli Süreli, s. 57.

135 Eyrenci/Taşkent/Ulucan, s. 53; Güler, Belirli Süreli, s. 57. 
arasında ayrım yapılmasını yasaklayan, İş Kanununun "Eşit Davranma İlkesi" kenar başlıklı 5. maddesinin altıncı fikrasına göre işveren, iş ilişkisinde veya sona ermesinde, eşit davranma ilkesine aykırı davrandığ 1 takdirde, işçi dört aya kadar ücreti tutarındaki uygun bir tazminatı ve yoksun kaldığı diğer haklarını talep edebiliri ${ }^{136}$.

Bu hüküm gereğince işçi, öncelikle ayrım nedeniyle mahrum kaldığ hakları, mesela ikramiyeyi talep edebilir. Bunun dışında, herhangi bir zarara uğrayıp uğramamasından bağımsız olarak ${ }^{137}$ dört aya kadarki ücreti tutarındaki bir tazminatı da talep edebilir ${ }^{138}$. Eğer işçinin zararı bu tazminattan fazla ise, bunu da genel hükümlere göre ayrıca talep edebilecektir.

\section{BELİRLİ SÜRELİ ISS SÖZLEŞMESINIIN SONA ERMESİ VE BUNUN HUKUKI SONUÇLARI}

\section{A. Kendiliğinden Sona Erme}

\section{Sürenin Dolması}

\section{a. Sürenin dolmasıyla kendiliğinden sona erme}

Belirli süreli iş sözleşmesinin en doğal sona erme nedeni sürenin dolmasıdır. Belirli süreli iş sözleşmesi, belirli bir süre için yapıldı̆̆ 1 ve bu sürenin sonuna kadar tarafları bağladığı için, sürenin dolmasıyla birlikte sözleşme de kendiliğinden, başkaca bir işleme gerek olmaksızın sona erer ${ }^{139}$.

Belirli süreli iş sözleşmesi, sürenin sonunda kendiliğinden sona erdiğinde, feshe bağlı hukukî sonuçlar da doğmayacaktır ${ }^{140}$. İhbar tazminatı, sadece belirsiz süreli iş sözleşmelerinde talep edilebileceği için, belirli süreli iş sözleşmesinin sürenin sonunda kendiliğinden sona ermesi durumunda gündeme gelmeyecektir.

İhbar tazminatı gibi, belirli süreli iş sözleşmesinin sürenin sonunda kendiliğinden sona ermesi durumunda kıdem tazminatı da talep edilemez.

136 Bu konuda ayrıntılı bilgi için bkz. Keser, Hakan: "4857 Sayılı İK’na Göre İşverenin İş Sözleşmesi Yapma ve İş İlişkilerinde Eşit İşlem Yapma Yükümlülükleri ve Bunlara Aykırı Davranması Durumunda Karşılaşacağı Yaptırımlar”, Kamu-İş Dergisi, 2004/3, s. $37 \mathrm{vd}$.

137 Güler, Belirli Süreli, s. 59.

138 Süzek, İş Hukuku, s. 208; Eyrenci/Taşkent/Ulucan, s. 54; Alpagut, 4857 Sayılı Yasa, s. 88.

139 Çelik, s. 171; Alpagut, Belirli Süreli, s. 160; Alpagut, 4857 Sayılı Yasa, s. 88; Stöckli, Jean - Fritz: "Belirli Süreli Hizmet Akdinin Sona Ermesi", (Çev. Ulucan, Devrim), Türk-İsviçre Hukukunda Belirli Süreli Hizmet Akitlerinin Hukuki Sorunları, Rehbinder/Ekonomi, İstanbul 1979, s. 77. TBKT m. 434/I: "Belirli süreli hizmet sözleşmesi, aksi kararlaştırılmadıkça, fesih bildiriminde bulunulmasına gerek olmaksızın, sürenin bitiminde kendiliğinden sona erer."

140 Narmanlığlu, Kıdem Tazminatı, s. 389; Alpagut, 4857 Sayılı Yasa, s. 88. 
Çünkü kıdem tazminatını düzenleyen 1475 sayılı Kanunun 14. maddesinde, hangi durumlarda adı geçen tazminatın istenebileceği belirtilirken, belirli süreli iş sözleşmesinin süre sonunda kendiliğinden sona ermesi nedenine yer verilmediği için, bu olasılıkta kıdem tazminatı talep edilemez ${ }^{141}$. Ancak Yargıtay, 625 sayılı Kanun gereğince belirli süreli iş sözleşmesiyle çalışan işçinin (öğretmenin), sürenin dolması nedeniyle iş sözleşmesinin sona ermesi durumunda kıdem tazminatı isteyebileceğine karar vermiştir. Yüksek Mahkeme, işverenin, süre sonunda sözleşmeyi yenilemeyeceğini bildirmesini fesih olarak nitelemiş ve bu sonuca varmıştır ${ }^{142}$. Yargıtay'ın bu kararları doktrinde ${ }^{143}$, belirli süreli iş sözleşmesinin süre sonunda kendiliğinden sona ereceği, süre sona ermeden önce işverenin gönderdiği ihtarname ile sözleşmeyi yenilemeyeceğini bildirmesinin fesih olmadığ 1 gerekçeleriyle haklı olarak eleştirilmektedir ${ }^{144}$.

141 Güler, Belirli Süreli, s. 60.

142 YHGK, 21.12.1994 tarih ve 768/869 sayılı kararından: “... Davacl, davalıya ait özel okulda 625 sayılı Yasa uyarınca belirli süreli sözleşmelerle çalışmakta iken, işverenin sözleşmenin bitiminden önce gönderdiği ihtarname ile yeni bir sözleşme yapmayacağını bildirmesi suretiyle iş̧en çıkarılmıştır. Dairemizin yerleşmiş içtihatlarına göre iş akdini yenilemeyeceğini bildiren işveren sözleşmeyi feshetmiş sayllır. Bu durumda kıdem tazminatı ödemekle yükümlü tutulmass gerekir. Mahkemenin, sürenin bitimi ile sözleşmenin kendiliğinden sona erdiğine ilişkin görüşü somut olaya ve dairemizin içtihatlarına uygun değildir." (Güler, Belirli Süreli, s. 60, dn. 69). Aynı yönde: Yargıtay 9. HD, 05.06.1980 tarih ve 6911/6758 sayılı kararı (Bu karar ve incelemesi için bkz. Taşkent, [İHU, İşK 9 (No: 5)]. Ayrıca bkz. Yargıtay 9. Hukuk Dairesinin 27.01.2003 tarih ve 2002/11889 E., 2003/161 K. sayılı kararından: “... Davacının (öğretmen) 1.8.1997 tarihinde işe başladiğ ve 5.7.1999 tarihinde ise iş akdinin işverence feshedildiği anlaşılmaktadır. Taraflar arasında 1.9.1997 - 31.8.1998 - 1.9.1998 31.8.1999 tarihlerini kapsayan iki ayrı sözleşme bulunduğu gibi, 1.8.1997 - 31.7.2000 tarihlerini de içine alan diğer bir sözleşme bulunmaktadır. Davacı, dava dilekçesinde belirttiği ve 2 yıllık tazminat tutarı olarak nitelendirdiği alacă̆ $\mathrm{kldem} \mathrm{tazminatı} \mathrm{olarak}$ istediklerini ifade etmiștir. Davacı ile davalı işveren arasında 31.8.1999 tarihinde sona erecek belirli süreli hizmet akdi yapılmış ise de, işveren akdin yenilenmeyeceğini 5.7.1999 tarihin de davacıya bildirmiş olup, dairemizin istikrar kazanmış kararlarına göre böyle bir bildirim fesih niteliği taşımaktadır. O halde akdi fesheden işveren kıdem tazminatı ödemekle yükümlüdür..." (Bu karar eHukukRehberi bilgi arşivinden alınmıştır).

143 Çelik, s. 86; Ekonomi, [İşK.9 (No:4)]; Güler, Belirli Süreli, s. 60; Mollamahmutoğlu, s. 10. Ayrica bkz. Sur, s. 272.

144 Karş. Narmanlıoğlu, İş Hukuku, s. 256. Bu kararlar hukuka aykırı olmakla birlikte, bunların, 625 sayılı Kanunun ortaya çıkardığ 1 adaletsizliği kısmen de olsa ortadan kaldırdığı bir gerçektir. Bu yöndeki görüşler için bkz. Şahlanan, Konferans Notları, s. 116; Güler, Belirli Süreli, s. 60, dn. 70'de belirtilen yazarlar. Alpagut ise, Yargitay'ın bu görüşünün yerinde olduğunu -değişik bir gerekçeyle- ileri sürmüştür (Alpagut, Değerlendirme, s. 91). 


\section{b. Sürenin dolmasına rağmen işçinin çalışmaya, işverenin de çalıştırmaya devam etmesi}

Borçlar Kanununun 339. maddesi, "Susma Ile Yenileme" kenar başlığını taşımaktadır ${ }^{145}$. Bu hükümde birbirinden farklı iki durum düzenlenmiştir. İlk fikrada, belirli süreli iş sözleşmesinin yaygın olan şekli, yani süre sonunda kendiliğinden sona erecek olan belirli süreli iş sözleşmesinin susma ile yenilenmesi ${ }^{146}$ düzenlenmiştir. Bu hükme göre, belirli sürenin sonunda sözleşme susma ile yenilenmişse, yani işçi çalışmaya işveren de çalıștırmaya devam etmișse, iș sözleşmesi eski sözleșmenin süresi oranında, ancak en fazla bir yıl için yenilenmiş sayılır. Böylece, belirli süreli iş sözleşmesinin süresinin bir yıldan az olması durumunda sözleşmesinin bu süre kadar yenilendiği, bir yıldan fazla olması durumunda ise, sözleşmesinin bir yıllık süre için yenileneceği hüküm altına alınmıştır ${ }^{147}$.

Aynı maddenin ikinci fikrasına göre ise, belirli süreli iş sözleșmesinin sona ermesinin, taraflardan birinin sürenin sona ermesinden belirli bir süre önce feshi ihbarda bulunmuş olması kaydına bağlanması durumunda, bu feshi ihbar, süre sonunda iş sözleşmesini sona erdirir. Ancak bu süre içinde sözleşmenin feshi ihbar etmemişse, sözleşmenin yenilenmiş olacağ 1 belirtilmiştir ${ }^{148}$. Bu maddede, yenilenen ikinci sözleşmenin süresine ilişkin bir hüküm bulunmaması, doktrinde görüş ayrılığına neden olmuştur. Bir

145 Sözleşmenin yenilenmesine ilişkin diğer bir hüküm, 625 sayılı Kanunun 32. maddesinde yer almıștır. Buna göre, süresi öğretim yılı içinde sona eren sözleșmeler, öğretim yılının sonuna kadar kendiliğinden yenilenmiş sayılır.

146 Borçlar hukuku anlamında yenileme, borcu sona erdiren bir neden olarak düzenlenmiş ve bir borcun yenisinin kabul edilmesiyle birlikte ortadan kaldırılması olarak tanımlanmıștır. $\mathrm{Bu}$ nedenle yenilemede, mevcut borç ifa edilmeden ortadan kaldırılmakta ve onun yerine diğer bir borç geçmektedir. Böylece, BK m. 114'de düzenlenen yenileme ile BK m. 339'da düzenlenen belirli süreli iş sözleşmesinin yenilenmesinin aynı olmadığ ortaya çıkmaktadır. Belirli süreli iş sözleşmesinde mevcut borç (sözleşme) ifa (sürenin dolması) ile sona ermekte, ancak işçinin çalışmaya, işverenin de çalıştırmaya devam etmesi, sözleşmenin yeniden kurulmasını sağlamaktadır. Sürenin sona ermesiyle ortadan kalkan iș sözleșmesi, tarafların zımnî iradeleriyle yeniden kurulmuş (yeni bir iș sözleșmesi kurulmuş) olmaktadır. Karş. Güler, Belirli Süreli, s. 62. Ancak doktrinde, bu durumda ilk sözleşmenin süresinin uzadığını ileri süren yazarlar da bulunmaktadır. Bu yönde: Alpagut, Belirli Süreli, s. 165. Mevzuatta yer alan bir hüküm, bu görüşü destekler niteliktedir. Gerçekten Deniz İș Kanununun 8. maddesinin ikinci fikrasına göre, "Belirli bir süre için yapılmıș olan hizmet aktinin sonunda gemi adamı ... ișe devam ederse hizmet akti, aynı süre için uzatılmış sayılır." Ancak, bu hükmün de, ilk görüşteki gibi anlaşılması gerektiği, diğer bir ifadeyle bu hükmün, BK m. 339 hükmü gibi anlaşılması gerektiği doktrinde ileri sürülmüştür. Bkz. Güler, Belirli Süreli, s. 62.

147 Ulucan, Sona Erme, s. 109; Güler, Belirli Süreli, s. 61. Karş. Stöckli, s. 92.

$148 \mathrm{Bu}$ nedenle, bu tür belirli süreli iş sözleşmelerinde feshi ihbar süresine uyulmamasının yaptırımı ihbar tazminatı değil, sözleşmenin yenilenmesi olacaktır. Güler, Belirli Süreli, s. 63; Alpagut, 4857 Sayılı Yasa, s. 89; Alpagut, Değerlendirme, s. 90. 
görüşe göre, bu durumda sözleşme, eski sözleşme süresince, ancak en fazla bir yıl için yenilenmiş sayılır ${ }^{149}$. Bu yorum maddenin ilk fikrasına uygundur. Diğer bir görüşte ise, ikinci fikrada ilk fikraya benzer bir hüküm bulunmaması nedeniyle, sözleşmenin bir yıllık sınıra bağlı olmaksızın yenileneceği ilk sözleşme süresinin ikinci sözleşmenin de süresini belirleyeceği ileri sürülmüştür ${ }^{150}$.

Bu hükümlerin, 4857 say1lı İş Kanunu karşısındaki durumlarının incelenmesi gerekmektedir ${ }^{151}$. 4857 sayılı Kanun, belirli süreli iş sözleşmesinin ilk yapıldığı tarihte bile objektif nedenlerin varlığını aramakta olduğu için, bu hükümler sadece, objektif nedenlerin bulunduğu durumlarda uygulanabilecektir. Zira iş sözleşmesinin süreye bağlanması ile bunun yapılabilmesi için objektif nedenlerin bulunması farklı durumlar olduğu için, Borçlar Kanununun bu hükmü, sadece sürenin belirlenmesiyle ilgilidir. Yoksa objektif nedenlere ilişkin bir durum değildir. Bu nedenle, ilgili hüküm gereğince yenilenme durumunda, objektif nedenlerin varlığ 1 yine de aranacak ve bulunmaması durumunda sözleşme belirsiz süreli iş sözleşmesi sayılacaktır ${ }^{152}$. Ancak, objektif nedenlerin bulunması nedeniyle yenilendiği kabul edilen iş sözleşmesinin yenilenme süresine ilişkin hükmünün, İş̧ Kanununa tâbi işlerde uygulanmayacă̆ 1 , diğer bir ifadeyle, sözleşmenin yenileneceği sürenin, eski sözleşme süresi veya bir y1l olmayacağ 1 doktrinde ileri sürülmüştür ${ }^{153}$. Mesela, haziran ayında biteceği öngörülen bir iş için yapılan 6 aylık belirli süreli iş sözleşmesinin, işin zamanında bitirilememesi nedeniyle yenilenmesi durumunda, bu sözleşmenin süresinin altı ay olmayacağı, aksine işin biteceği öngörülen süre olması gerektiği savunulmuştur. $\mathrm{Bu}$ olayda, haziran ayındaki tespitlere göre işin ağustos ayında biteceği öngörülebiliyorsa, iş sözleşmesi iki aylık süre için yenilenmiş sayılmalıdır ${ }^{154}$.

Kanaatimce bu görüş yerindedir. Çünkü belirli süreli iş sözleşmesinin yapılabilmesi için aranan, sürenin sonunun objektif olarak öngörülebilmesi,

149 Eyrenci/Taşkent/Ulucan, s. 57; Ulucan, Sona Erme, s. 110; Nitekim Yargıtay da bir kararında aynı sonuca varmıştır [Bkz. 9. HD, 28.02.1995, 1994/16836 E., 1995/6017 K. sayılı karar (Güler, Belirli Süreli, s. 63, dn. 76].

150 Narmanlıŏ̆lu, İş Hukuku, s. 256; Çelik, s. 172; Alpagut, Belirli Süreli, s. 172; Alpagut, 4857 Sayılı Yasa, s. 89; Güler, Belirli Süreli, s. 62.

151 Doktrinde, Borçlar Kanununun bu hükmünün, 4857 sayılı Kanun karşısında, sadece belirli sürenin açıkça gün, ay ve yıl olarak belirlendiği hallerde uygulanabileceği ileri sürülmüştür. Bkz. Çelik, s. 172. Ayrıca, 4857 sayılı Kanuna tûbi işlerde, bu hükümlerin (BK m. 339) uygulanmasının mümkün olmadığ da ileri sürülmektedir. Bu yönde: Alpagut, 4857 Sayılı Yasa, s. 89; Mollamahmutoğlu, s. 10.

152 Güler, Belirli Süreli, s. 63.

153 Alpagut, 4857 Sayılı Yasa, s. 89.

154 Alpagut, 4857 Sayılı Yasa, s. 89. 
bu durumda da aranmalıdır. İkinci sözleşmenin belirli süreli olma özelliğini taşıyabilmesi için objektif neden yanında, işin bitiminin objektif olarak öngörülebilir olması da arandığ 1 için, yenilenen sözleşmenin süresinin eski sözleşme süresiyle sınırlı olmayacağı, aksine işin biteceği öngörülen sürenin sonu olacağının kabul edilmesi gerekir.

Türk Borçlar Kanunu Tasarısının belirli süreli iş sözleşmesinin sona ermesini düzenleyen 434. maddesinin ikinci fikrasında ise, "belirli süreli sözleşme, süresinin bitiminden sonra örtülü olarak sürdürülüyorsa, belirsiz süreli sözleşmeye dönüşür. Ancak, esaslı nedenlerin varlı̆̆ halinde üst üste belirli süreli hizmet sözleşmeleri kurulabilir." hükmü getirilmiştir. Görüldüğü gibi bu hükümde, esaslı neden (objektif koşul) bulunmadığ 1 sürece, iş sözleşmesinin belirsiz süreli hale geleceği belirtilmiştir. Aynı şekilde, anılan maddenin sonuncu fikrasına göre, "sözleşmenin fesih bildirimiyle sona ereceği kararlaştırılmış ve iki taraf da fesih bildiriminde bulunmamışsa, sözleşme belirsiz süreli sözleşmeye dönüşür."

\section{2. Ölüm}

Belirli süreli iş sözleşmesinin ikinci doğal sona erme nedeni, ölümdür.

Iş̧̧̧inin ölmesi, BK m. 347/I gereğince iş sözleşmesinin kendiliğinden sona erdirir. İşçinin ölmesi nedeniyle belirli süreli iş sözleşmesinin sona ermesi, ölen işçinin kanunî mirasçılarına işverenden kıdem tazminatı isteme hakkı verecektir ${ }^{155}$. Çünkü, kıdem tazminatına ilişkin 1475 sayılı Kanunun 14. maddesinde işçinin ölmesi, kıdem tazminatına olanak veren bir sona erme nedeni olarak düzenlenmiştir.

Türk Borçlar Kanunun Tasarısının 444. maddesinde, işçinin ölümünün iş sözleşmesini kendiliğinden sona erdireceği belirtildikten sonra, bu durumda işverenin, işçinin sağ kalan eşine ve ergin olmayan çocuklarına, bunlar yoksa, ölen işçinin bakmakla yükümlü olduğu kişilere, ölüm gününden başlayarak bir aylık, iş ilişkisi beş yıldan fazla bir süre devam etmişse iki aylık ücret tutarında bir ödemede bulunmakla yükümlü olduğu düzenlenmiştir. Görüldüğü gibi bu hükümle, mevcut düzenlemeden farklı olarak işverene bir aylık veya iki aylık ücret tutarında bir ödemede bulunma yükümlülüğü getirilmiştir.

İ̧̧verenin ölmesi ise, her zaman iş sözleşmesini sona erdirmez ${ }^{156}$. BK m. 347/II hükmüne göre, iş sözleşmesi işverenin kişiliği dikkate alınarak yapılmış ise, işverenin ölümüyle sözleşme sona erer. Aksi takdirde iş sözleşmesi, işçi ile ölen işverenin mirasçıları arasında devam eder.

İşs sözleşmesinin işverenin kişiliği dikkate alınarak yapılmış bulunması durumunda, işverenin ölmesi iş ilişkisini sona erdirmesine rağmen, bu durum

155 Çelik, s. 170.

156 Çelik, s. 170. 
işçiye kıdem tazminatı talep etme hakkı vermeyecektir. Çünkü kıdem tazminatına ilişkin maddede, bu durum (işverenin ölmesi nedeniyle iş sözleşmesinin sona ermesi) kıdem tazminatına hak kazandıran bir sona erme nedeni olarak düzenlenmemiştir.

Ayrıca, BK m. 347/III hükmünde, işverenin ölümünün iş ilişkisini sona erdirdiği durumda, işçinin, iş sözleşmesinin erken -vaktinden öncesona ermesi nedeniyle uğrayacağ 1 zarar için hakkaniyete uygun bir tazminat isteyebileceği belirtilmiştir. Doktrinde belirtildiği gibi, bu tazminatın miktarı, belirli süreli iş sözleşmesinin süresinden önce işverence haklı sebep bulunmaksızın feshedilmesi durumunda BK $\mathrm{m}$. 325'e göre talep edebileceği tazminattan fazla olmamalıdır ${ }^{157}$.

\section{B. Anlaşma Yoluyla Sona Erme (İkale)}

Sözleşme özgürlüğü gereğince, mevcut bir sözleşme ilişkisi tarafların ortak iradesiyle her zaman sona erdirilebilir. Aynı esas iş sözleşmeleri için de geçerlidir. Buna göre, iş sözleşmesinin tarafları, gerek belirsiz süreli, gerekse de belirli süreli iş sözleşmesini ortak iradeleriyle her zaman ortadan kaldırabilirler.

Anlaşma yoluyla iş sözleşmesinin sona erdirilmesi bir fesih olmadığı için, bu durumda feshe bağlı hukukî sonuçlar ortaya çıkmayacak, mesela işçi bu durumda kidem tazminatı talep edemeyecektir ${ }^{158}$.

Anlaşma yoluyla sözleşme ilişkisinin ortadan kaldırılabilmesinin temeli sözleşme özgürlüğü olduğu için, iş hukukundaki zayıf taraf olan işçinin korunması ilkesi gereğince, işçinin iradesinin tam olarak bulunması gerekmektedir. $\mathrm{Bu}$ nedenle, Yargitay'ın ibranameler için kabul ettiği esasların, ikale için de uygulanması gerektiği doktrinde haklı olarak ileri sürülmüştür ${ }^{159}$.

Belirli süreli iş sözleşmesinde kararlaştırılmış olan sürenin taraflarca kısaltılması, ikale değil, değişiklik anlaşması olduğu için, bu kısaltılmış sürenin sonunda iş sözleşmesi sona erdiğinde sözleşme sürenin sona ermesiyle ortadan kalkacağ 1 için, işçi kıdem tazminatı isteyemez.

\section{Bildirimli Fesihle Sona Erme}

Belirli süreli iş sözleşmesinde tarafların sözleşmeyi bildirimli olarak feshetmeleri mümkün değildiri ${ }^{160}$.

Ancak bildirimli feshe olanak veren bir hüküm BK m. 343'de düzenlenmiştir. Bu hükme göre, iş sözleşmesinin, bir tarafin ömrü boyunca

\footnotetext{
Çelik, s. 171; Güler, Belirli Süreli, s. 65; Alpagut, Belirli Süreli, s. 159.

Narmanlığlu, Kıdem Tazminatı, s. 390; Güler, Belirli Süreli, s. 64.

59 Güler, Belirli Süreli, s. 64.

160 Çelik, s. 177.
} 
ya da on yılı aşkın bir süre için yapılması durumunda, on yıldan sonra işçiye bildirimli fesih hakk1 verilmiștir.

Görüldüğü gibi, bu hükümle işçiye, iki durumda bildirimli fesih hakk1 tanınmıştır. Bunlardan ilki, sözleşmenin taraflardan birinin ömrü boyunca yapılmış olmasıdır. Taraflardan birinin ömrü boyunca yapılmış bir iş sözleşmesi, gerçekte belirsiz süreli bir iş sözleşmesidir. Hukukî işlemin sonuçlarının bir kişinin ölümüne bağlanması teknik anlamda belirsiz vade olarak nitelendirilmektedir. Çünkü, tarafların ölümü kesin, ancak ne zaman gerçekleșeceği belli olmayan bir olay olduğu için, bunun bozucu şart olarak kabulü mümkün değildir ${ }^{161}$. Kaldı ki bozucu şarta bağlı olarak yapılan iş sözleşmelerinin de belirli süreli kabulü mümkün olmadığ 1 için ${ }^{162}$, bir kişinin hayatı boyunca yapılan iş sözleşmesinin belirsiz süreli olduğunun kabulü gerekir. Böylece, taraflardan birinin hayatı boyunca devam edecek bir iş sözleşmesinin bildirimli feshi için on yılın dolmasının gerekli olmadığı sonucuna varllabilir ${ }^{163}$.

İlgili maddede geçen diğer durum ise, sözleşmenin süresinin 10 yılı aşkın bir süre olarak belirlenmiş olmasıdır. Mesela sözleşmenin 15 yıllık bir süre için yapılmış olması durumunda, on yıllık sürenin sonunda, işçinin bildirimli fesih hakkı bulunmaktadır.

$\mathrm{Bu}$ durumda sadece işçinin bildirimli fesih hakkı vardır. Yoksa işveren, bu hükme dayanarak on yıldan sonra iş sözleșmesini bu hükme göre feshedemez ${ }^{164}$. İşçi bu hakkını, dilediği bir zamanda, bir aylık ihbar süresiyle birlikte kullanabilir. Diğer bir ifadeyle, on yılın sonunda iş̧̧i, dilediği zamanda, bir ay öncesinden bildirimde bulunmak kaydıyla, iş sözleşmesini feshedebilir.

İş sözleşmesinin işçi tarafından bu şekilde feshinin ihbar edilmesi yoluyla sona erdirilmesi, 1475 sayılı Kanunun 14. maddesine göre ișçiye kıdem tazminatı talep hakkı vermez. Ancak, işçinin bir aylık bildirim süresine uymaması durumunda, işveren bu nedenle uğrayacağı zararının tazminini talep edebilir. Doktrinde de belirtildiği gibi bu tazminat, niteliği itibariyle ihbar tazminatı olmayıp, bildirim süresine uyulmamasından doğan gerçek zararı karşılamaya yönelik bağımsız bir tazminattır ${ }^{165}$. Bu tazminatın miktarı, işverenin uğradığı zararla sınırlıdır. İşçinin bu bildirim süresine uyarak sözleşmeyi feshetmesi durumunda ise, işverenin uğrayacağ 1 zararların işçiden talebi mümkün değildir.

61 Güler (Belirli Süreli, s. 80) bunu bozucu şart olarak nitelemiştir.

62 Bkz. Ertürk, s. 232.

163 Alpagut, Belirli Süreli, s. 174; Alpagut, 4857 Sayılı Yasa, s. 90.

164 Alpagut, Belirli Süreli, s. 173; Güler, Belirli Süreli, s. 81.

165 Güler, Belirli Süreli, s. 81. 
$\mathrm{Bu}$ hüküm, Türk Borçlar Kanunu Tasarısında farklı bir şekilde düzenlenmiştir ${ }^{166}$. Öncelikle, taraflardan birinin hayatı boyunca devam edecek olan sözleşmelerde, feshi ihbar için on yıllık sürenin dolmasının açıkça aranmadığını görülmektedir. Zira bu hükümde, ömür boyunca devam edecek sözleşmelere ilişkin bir kurala yer verilmemiştir. $\mathrm{Bu}$ nedenle Tasarının, bu tür sözleşmeleri belirsiz süreli sözleşme saydığı kabul edilebilir. Tasarının ikinci farklı düzenlemesi, ihbar süresinin bir aydan altı aya çıkarmış olmasıdır. Gerçekten anılan hükümde, on yıl dolduktan sonra, altı aylık ihbar süresine uyularak sözleşmenin her zaman feshedilebileceği düzenlenmiştir. Bunun yanında, işbu feshin izleyen ay başında hüküm ifade edeceği de belirtilmiştir. Tasarının son farkı ise, mevcut hükmün aksine, bu şekilde feshi ihbar hakkını sadece işçiye değil, işverene de tanımış olmasıdır.

\section{Bildirimsiz Fesihle Sona Erme}

\section{1. İșeren Tarafindan}

\section{a. Haklı nedenle}

İş Kanununun 25. maddesinde belirtilen nedenlerle işveren, iş sözleşmesini bildirimsiz olarak feshedebilir. İş sözleşmesinin bu şekilde feshi, iş sözleşmesini derhal sona erdirir.

İş sözleşmesinin işveren tarafından haklı nedenlerle feshedilmiş olması işçinin hiçbir zaman kıdem tazminatı alamaması sonucunu doğurmaz. Çünkü 1475 sayılı Kanunun 14. maddesinde, sadece işverenin haklı nedenle feshinin, "ahlak ve iyiniyet kurallarina uymayan haller ve benzerleri" nedenine dayanması durumunda işçinin kıdem tazminatı alamayacağ 1 düzenlenmiş bulunduğu için, işverenin haklı nedenle feshinin sağlık nedenlerine veya zorlayıc1 nedenlere ve $25 / \mathrm{IV}$ 'de belirtilen hallere dayanması durumunda işçi kıdem tazminatına hak kazanacaktır. Diğer bir ifadeyle, iş sözleşmesi işverence, işçinin ahlak ve iyiniyet kurallarına aykırı davranışı nedeniyle feshedilmişse, işçi kıdem tazminatı talep edemeyecek, diğer nedenlere dayalı fesihte ise talep edebilecektir.

İhbar tazminatı sadece bildirimli fesihte talep edilebilen bir işçilik hakkı olduğu için, bu olasılıkta ihbar tazminatı talep edilemeyecektir ${ }^{167}$.

166 TBKT m. 434/III: "Taraflardan her biri, on yıldan uzun süreli hizmet sözleşmesini, on yıl geçtikten sonra, altı aylık fesih süresine uyarak feshedebilir. Fesih, ancak süreyi izleyen aybaşında hüküm ifade eder."

167 Yargitay 9. HD, 27.10.2004 tarih ve 5632/24444 sayılı kararına konu olan olayda taraflar, iş sözleşmesinin 5. maddesiyle, haklı neden bulunmaksızın sözleşmeyi fesheden tarafın, karşı tarafa belli miktarda cezaî şart ödeyeceğini kararlaştırmışlardır. Ancak aynı sözleşmede, haklı nedenle sözleşmeyi fesheden tarafin cezaî şart isteyebileceğine ilişkin bir kayıt bulunmadığı için Yargitay, işçinin, fesih, haklı nedenlere dayansa bile, cezaî şart isteyemeyeceğine karar vermiştir (Çalışma ve Toplum Dergisi, 2005/1, s. 290). 


\section{b. Haklı neden bulunmaksızın}

\section{aa. Genel olarak}

Belirli süreli iş sözleşmesinin süresinden önce işveren tarafından haklı nedenler bulunmaksızın feshedilmesi durumunda, ortaya çıkacak hukukî sonuca ilişkin birbirinden farklı görüşler bulunmaktadır. Bu görüşler, belirli süreli iş sözleşmesinin, haklı nedene dayanmayan fesih bildiriminin, sözleşmeyi sona erdirip erdirmeyeceği noktasında ortaya çıkmaktadır. Bu nedenle işbu görüşlere değinilmesinde yarar bulunmaktadır.

\section{Haksız feshi, alacaklının temerrüdü sayın görüş}

Bu konuda ileri sürülen ve doktrinde hâkim durumda olan bu görüş gereğince $^{168}$, işverenin belirli süreli iş sözleşmesini haklı neden bulunmaksızın feshetmesi, iş sözleşmesini ortadan kaldırmaz. Çünkü belirli süreli iş sözleşmesinde, tarafların haklı nedenle fesih dıșında bir fesih olanağ 1 bulunmamaktadır ${ }^{169}$. Bu nedenle işverence yapılan ve haklı nedenlere dayanmayan fesih, geçersiz bir fesih niteliğindedir. Bu görüşte, haksız feshin geçersizliğinin, iş güvencesine ilişkin hükümler nedeniyle feshin geçersiz sayılmasıyla aynı anlama sahip olmadığı ve bunun, feshin yapılmamış sayılması sonucunu doğurduğu ileri sürülmüştür ${ }^{170}$.

$\mathrm{Bu}$ görüşte, işverenin fesih beyanı, haklı nedenlere dayanmadığı için iş sözleşmesini sona erdirmemektedir. Ancak işveren, böylece işçiyi çalıştırmamak veya diğer bir ifadeyle; işçi tarafından sunulan iş görme edimini kabulden kaçınmak suretiyle alacaklının temerrüdüne düştüğü için işçi, sözleşmenin bitimine kadar ki dönem için ücretini isteyebilecektir ${ }^{171}$. Zira, tam iki taraf borç yükleyen bir sözleşme olan iş sözleşmesinde işveren, işçinin iş görme borcunu kabul etmemek (fesih beyanı ile işçinin çalışmasına engel olmak) suretiyle alacaklının temerrüdüne düşmektedir. İşverenin alacaklının temerrüdüne düşmesi iş sözleşmesini ortadan kaldırmadığı ve sözleşme normal olarak sürenin sonuna kadar ayakta kalıp, süre sonunda

168 Bu görüşte olan yazarlar: Eyrenci, Öner: "Belirli Süreli Hizmet Akdinin İşverence Feshedilmesinin Hukuki Sonuçları" [İHU, İşK 9, (No: 2)]; Elbir, Halid Kemal: "Belirli Süreli Hizmet Akdinin İşverence Haksız Feshi Halinde Cezai Şart" [İHU, İşK 9, (No: 3)]; Sümer, Haluk Hadi: "Belirli Süreli Hizmet Sözleşmelerinde Haksız Feshin Hukuki Sonuçları", TÜHİS, Şubat 1992/8, s. 6; Ulucan, Sona Erme, s. 115.

169 Eyrenci'ye göre tarafların, belirli süreli iş sözleşmesi yapmalarına rağmen fesih hakkını da saklı tutmaları (azamî süreli iş sözleşmesi) mümkün olduğu için, bu yönde bir belirleme yapılmamışsa, belirli süreli iş sözleşmesinin süresinden önce feshinin geçerli olmayacağı kabul edilmelidir. Eyrenci, [İHU, İşK 9, (No: 2)]. Aynı yönde: Sümer, s. 6.

170 Güler, Belirli Süreli, s. 68. Karş. Eyrenci/Taşkent/Ulucan, s. 56; Eyrenci, [İHU, İşK 9, (No: 2)]; Ulucan, Sona Erme, s. 114.

171 İşverenin alacaklının temerrüdüne düşmesi, işçi bakımından haklı neden oluşturur. Bkz. Eyrenci, [IHHU, İşK 9, (No: 2)]. 
kendiliğinden sona ereceği için ${ }^{172}$ işçi, kıdem tazminatına veya ihbar tazminatına hak kazanamaz ${ }^{173}$.

$\mathrm{Bu}$ durumda işçi $\mathrm{BK}$ m. 325 gereğince, iş sözleşmesinin süresinin bitimine kadarki süre için ücretini isteyebilir. Ancak bu ücretten, işçinin çalışmamak suretiyle tasarruf ettiği ve kasten elde etmediği diğer gelirler indirilir. Bu görüşte, bakiye süreye ilişkin talep tazminat değil, ücret olarak nitelendirilmektedir.

\section{Haksız feshi, sonraki kusurlu imkânsızlık sayan görüş}

$\mathrm{Bu}$ görüşte de, işverenin fesih beyanının iş sözleşmesini sona erdirmediği, ancak ilk görüşten farklı olarak, işverenin bu davranışıyla, işçinin iş görme borcunu ifa etmesini imkânsız hale getirdiği, bunda da işverenin kusurlu bulunması nedeniyle, işverenin davranışının sonraki kusurlu imkânsızlık teşkil ettiği ileri sürülmektedir ${ }^{174}$. Bu görüşte iş sözleşmesi işverenin fesih beyanıyla değil, bu beyanın sonraki kusurlu imkânsızlık teşkil etmesi nedeniyle sona ermektedir. Bu görüşün sahibi Oğuzman'a göre ${ }^{175}$, iş sözleşmesi fesihle değil imkânsızlık nedeniyle sona erdiği için, işçi kıdem tazminatı talep edemez. Ancak işverenin, sözleşmenin imkânsızlık nedeniyle sona ermesinde kusuru bulunduğu için, işçi gerek sözleşmenin süresinin sonuna kadarki zararını, gerekse de, kıdem tazminatını, haksız davranış nedeniyle tazminat olarak isteyebilir.

\section{Haksı feshin sözleşmeyi sona erdirdiğini kabul eden görüş}

$\mathrm{Bu}$ konudaki diğer görüş ise, işverenin feshinin, haklı nedenleri bulunmasa da iş sözleşmesini sona erdirdiği esasına dayanmaktadır ${ }^{176}$.

172 Türk Borçlar Kanununu Tasarısının işverenin temerrüdüne ilişkin 412. maddesine göre, "Işveren, iş görme ediminin yerine getirilmesini kusuruyla engellerse veya edimi kabulde direnime düşerse işçiye ücretini ödemekle yükümlü olup, işçiden bu edimini daha sonra yerine getirmesini isteyemez. Ancak, işçinin bu engelleme nedeniyle yapmaktan kurtulduğu giderler ile bașka bir iş yaparak kazandiğı veya kazanmaktan bilerek kaçındiğı yararlar ücretten indirilir."

173 Bkz. Çelik, s. 238; Narmanlığlu, Kıdem Tazminatı, s. 394; Güler, Belirli Süreli, s. 68.

174 Bkz. ve karş. Çelik, s. 238; Narmanlığlu, Kıdem Tazminatı, s. 396; Güler, Belirli Süreli, s. 69; Eyrenci, [İHU, İşK 9, (No: 2)].

175 Oğuzman, Kemal: Türk Borçlar Kanunu ve İş Mevzuatına Göre Hizmet (İş) Akdinin Feshi, İstanbul 1955, s. 143 vd. (Narmanlığlu, Kıdem Tazminatı, s. 396'dan naklen).

176 Bu görüşte olan yazarlar: Çelik, s. 238, 239; Narmanlıoğlu, İş Hukuku, s. 432, 433; Narmanlığlu, Kıdem Tazminatı, s. 405; Ekonomi, Münir: "Kıdem Tazminatına Hak Kazanılan Hallerde Fesih Kavramı ve Türleri”, Kamu-Işs Dergisi, Ocak 1990, s. 10 vd.; Alpagut, Belirli Süreli, s. 177 vd.; Alpagut, 4857 Sayılı Yasa, s. 90; Alpagut, Değerlendirme, s. 95; Güler, Belirli Süreli, s. 69. 
Böylece işverenin feshi, haksız bir fesih olarak bunun bütün hukukî sonuçlarını doğuracaktır ${ }^{177}$.

Doktrinde genel olarak, belirli süreli iş sözleşmesinde haklı nedene dayanmayan feshin düzenlenmemesinin bir kanun boşluğu oluşturduğu kabul edilmektedir ${ }^{178}$. Ancak bu görüşte, haklı nedenle fesih dışında fesih olanağının düzenlenmemesinin, haklı nedene dayanmayan feshin yapılamayacağ1 sonucunu doğurmayacağı ileri sürülerek, belirli süreli iş sözleşmesinde feshi yasaklayan bir hükmün bulunmadığ 1 belirtilmiştir ${ }^{179} . \mathrm{Bu}$ nedenle mevcut boşluğun, sözleşmenin feshinin haklı nedenleri bulunmasa da sözleşmeyi sona erdireceğinin kabul edilmesi yoluyla doldurulması gerektiği ileri sürülmüştür. Bakiye süreye ilişkin talep bakımından ise, işçinin aleyhine sonuçlar doğuran BK m. 325 hükmünün kıyas yoluyla uygulanması suretiyle, anılan maddede belirtilen esaslar dikkate alınarak tazminat miktarının belirlenmesi gerekir ${ }^{180}$.

Narmanlıŏlu'na göre de işverenin haklı neden olmaksızın süresinden önce iş sözleşmesini feshetmesi mümkündür ${ }^{181}$. Çünkü, "buradaki 'işverenin haksız feshi' deyimi, bir hakkın kullanılması anlamını taşımamakta, kanuna aykirı olduğu kuşkusuz olan bir davranışın sonuçta büründüğ̈̈ biçimi anlatmaktadır. Bu itibarla, işverenin sonucu itibariyle fesih sayılacak davranışını hukuken fesih sonuçlarına bağlayabilmek için, işverenin iş sözleşmesini haksı olarak feshetme hususunda bir yenilik doğuran hakkının varlığı gerekli değildir. ... işverenin, işsözleşmesinin haklı olarak ... feshedilmesi hususunda bir yenilik doğuran hakka sahip bulunduğunu, bunun dışında böyle bir davranışta bulunamayacağını Türk Hukuku bakımından söyleyebilmek mümkün değildir."

Ekonomi, belirli süreli iş sözleşmesinde haksız feshin iş sözleşmesini sona erdirdiğine ilişkin yasal dayanağın, İş Kanununun 23. maddesinin birinci fikrasında yer aldığını ileri sürmüştür ${ }^{182}$. Gerçekten bu hükme göre, belirli süreli iş sözleşmesiyle çalışan işçi, süresinden önce işi bırakıp başka bir işverenin işinde çalışmaya başlarsa, “...sözleşmenin bu surette feshinden

177 Eyrenci/Taşkent/Ulucan (s. 56), bu konudaki görüşleri açıklamamakla birlikte, sözleşmenin sona erdiğinin kabul edilmesi halinde, iş güvencesine ilişkin hükümlerin de tartışma konusu yapılması gerektiğini belirtmiştir. Ancak kanaatimce, bu konunun bir önemi bulunmamaktadır. Çünkü İş Kanununun 18. maddesine göre, belirli süreli iş sözleşmesiyle çalışan işçiler, iş güvencesine ilişkin hükümlerden yararlanamazlar.

178 Bkz. Güler, Belirli Süreli, s. 71.

179 Güler, Belirli Süreli, s. 71.

180 Çelik, s. 239; Güler, Belirli Süreli, s. 72.

181 Narmanlığ̆lu, Kıdem Tazminatı, s. 398, dn. 53.

182 Ekonomi, Münir: Genel Görüșme, Yargıtayın İş Hukukuna İlișkin 1998 Kararlarının Değerlendirilmesi, İstanbul 2000, s. 161. 
ötürü...” sorumlu olur. Yazara göre bu hükümden, belirli süreli iş sözleşmesinde hakl1 nedene dayanmayan feshin, iş sözleşmesini sona erdirdiği sonucu çıkarılabilir.

Engin'e göre, 1475 say1lı İş Kanununun 14. maddesinde sözleşmenin haksız feshine kıdem tazminatı sonucu bağlandığı, ve bu, sadece belirsiz süreli iş sözleşmelerine inhisar ettirilmediği için, bu hükümden, belirli süreli iş sözleşmesinin, haklı neden bulunmasa bile sona erdirilebileceği sonucu çıkarılmalıdır ${ }^{183}$.

Yargıtay'ın görüşü de bu yöndedir. Ancak bazı kararlarda bakiye süreye ilişkin istemler "ücret", bazılarında ise "tazminat" olarak nitelendirilmekte, fakat istikrarlı bir biçimde, işçinin kıdem tazminatı isteyebileceği belirtilmektedir ${ }^{184}$.

Kanaatimce de yukarıda açıklanan gerekçelerle, fesih beyanının, haklı nedenlere dayanmasa bile iş sözleşmesini sona erdirdiğinin kabul edilmesi, iş hukukunun işçiyi koruyucu özelliğine daha uygun olacaktır. Böylece işçinin bakiye süreye ilişkin talebinin bir tazminat niteliğinde olduğu ve işçinin bu haksız fesih nedeniyle kıdem tazminatı isteyebileceği kabul edilmelidir.

Hemen belirtelim ki, bu konudaki boşluk, Türk Borçlar Kanununu Tasarısının 442. maddesi ile doldurulmak istenmektedir. Tasarının bu hükmüne göre, belirli süreli iş sözleşmesinde fesih, haklı nedenlere dayanmasa bile sözleşmeyi sona erdirir. Böylece işçi, sözleşmenin bu şekilde feshi nedeniyle doğan zararını (sürenin sonuna kadarki kazanç kaybını), tazminat olarak isteyebilecektir. Ayrıca, iş sözleşmesinin süresinden önce feshiyle işçinin tasarruf ettiği miktar ile başka bir işten elde ettiği veya bilerek elde etmekten kaçındığg gelir de bu tazminattan indirilir. Görüldüğü gibi Tasarının bu hükmü, ilk iki fikrasıyla, doktrinde savunulan sonuncu görüş doğrultusunda, haksız feshin sözleşmeyi sona erdireceği yönündedir. $\mathrm{Bu}$ nedenle, mevcut boşluğun doldurulduğu söylenebilir. Kaldı ki, bu hükümle haksız feshin sözleşmeyi sona erdirdiği kabul edildiği için, işçi bu madde geçeğince tazminat isteminden başka, kıdem tazminatı da isteyebilecektir. Bu yönüyle, hükmün yerinde olduğu düşünülebilir.

\footnotetext{
bb. Sonuçları

aaa. Sözleşmenin süresinden önce sona erdirilmesi nedeniyle, işçinin bakiye süreye ilişkin zararının tazmini

Belirli süreli iş sözleşmesinin süresinden önce işverence haklı neden

183 Engin, Murat: “İş Hukuku Uygulamasında Borçlar Kanunu”, İstanbul Barosu Çalışma Hukuku Komisyonu Bülteni, 2001/5, s. 88. Bu yönde: Narmanlığlu, Kıdem Tazminatı, s. 386.

184 Bkz. aşa. V, D, 1, b, bb, bbb. Ayrıca bkz. Narmanlıoğlu, Kıdem Tazminatı, s. 398.
} 
bulunmaksızın feshedilmesi halinde, işçinin kalan süreye ilişkin menfaatlerini, daha doğru bir ifadeyle zararını işverenden talep edebileceği kabul edilmektedir ${ }^{185}$. İşverenin haksız feshinin sözleşmeyi sona erdirdiği görüşü gereğince, işçinin bakiye süreye ilişkin zararının hesaplanmasında, $\mathrm{BK}$ m. 325'in doğrudan değil, kıyasen uygulanabileceği ileri sürülmüsstür ${ }^{186}$. $\mathrm{Bu}$ hükme göre işçi, geri kalan süreye ilişkin ücretini, işverenden talep edebilir. Kanunda geçen ücret teriminin, iş sözleşmesinin feshedilmiş olması nedeniyle tazminat olarak anlaşılması gerekmektedir ${ }^{187}$. İşçi bu süreye ilişkin ücreti tutarında tazminat talep edebilir.

$\mathrm{Bu}$ tazminatın hesabında dikkate alınacak olan ücret, geniş anlamda ücrettir. Ancak, sürenin kalan kısmında yapılacak olan zamların dikkate alınmaması gerektiği, aksi yorumun, talebin tazminat esasına dayandığ 1 ilkesine aykırı olacağı ileri sürülmüştür ${ }^{188}$.

İşçinin talep edebileceği bu tazminattan, işçinin çalışmamak suretiyle tasarruf ettiği miktar ile diğer bir işte çalışmak suretiyle elde ettiği ya da kasten elde etmekten kaçındığ1 gelir mahsup edilecektir ${ }^{189}$. Böylece ilk olarak, süresinden önce sona eren belirli süreli iş sözleşmesinin kalan süresi için, mesela işçinin harcayacağ 1 yol parası gibi kalemler ödenecek tazminattan mahsup edilecektir. Bunun yanında, işçinin serbest kalması nedeniyle yeni bir işte çalışması durumunda, bu iş̧e çalışarak elde ettiği geliri de mahsup edilir. Ancak, işçinin bakiye süre içinde çalışmaması halinde, o işçinin özelliklerini taşıyan ortalama bir işçinin ne kadar süre içinde ve ne kadar maaşla yeni bir iş bulabileceği de hesaplanarak, elde edilebilecekken işçinin ihmali nedeniyle elde edilmemiş bulunan olası gelir de, ödenecek tazminattan indirilir. Bu mahsup işlemi hâkim tarafından kendiliğginden yapı1ır ${ }^{190}$.

185 Haksız feshin hukukî niteliğine ilişkin bütün görüşlerde, işçinin bakiye süreye ilişkin talebi kabul edilmekte iken, bu talebin niteliği (tazminat - ücret) bakımından görüş ayrılığı bulunmaktadır.

186 Narmanlıŏ̆lu, Kıdem Tazminatı, s. 402 vd.

187 Alpagut, Belirli Süreli, s. 184; Engin, s. 89. Ancak bazı Yargıtay kararlarında, bakiye süreye ilişkin talebin ücret olarak nitelendirildiği görülmektedir. Bu yönde: 9 . HD, 30.01.2003, 2002/12236 E., 2003/970 K. sayılı kararı (Güler, Belirli Süreli, s. 71, dn. 97).

188 Güler, Belirli Süreli, s. 74.

189 Çelik, s. 239; Alpagut, Belirli Süreli, s. 187.

190 Güler, Belirli Süreli, s. 75. Yargitay 9. Hukuk Dairesinin 12.06 .1967 tarih ve 5377/5485 sayılı kararından: “... hakkın doğumuna ilişkin istekler, teknik anlamda def'i olarak nitelendirilemezler. Bundan başka daval, mahsup savunmasinda bulunmak ve savunmasını ispat etmekle de yükümlü değildir. Tersine, işsözleşmesinin süresinden önce bozulduğunu iddia eden davacı, bu bozmadan dolayı gerçek zararını ve dolayıslyla, zarardan indirme yapılmasını gerektiren bir kazancın olmadı̆̆ını ispatla yükümlüdür ..." (Güler, Belirli Süreli, s. 76, dn. 115]. 
$\mathrm{Bu}$ hüküm, Borçlar Kanunu Tasarısında ise farklı bir biçimde düzenlenmiştir. Gerçekten anılan Tasarının 442. maddesinin son fikrası, farklı anlamalara meydan verecek bir ifade taşımaktadır. Bu hükme göre: "Hakim, bütün durum ve koşulları göz önünde tutarak, miktarını serbestçe belirleyeceği bir tazminatın işçiye ödenmesine karar verebilir; ancak belirlenecek tazminatın miktarı, işçinin altı aylık ücretinden fazla olamaz." $\mathrm{Bu}$ hüküm karşısında iki farklı şekilde düşünülebilir.

İlk olarak bu hükmün, belirli süreli iş sözleşmesinin süresinden önce haklı neden bulunmaksızın işverence feshi durumunda, işçinin bakiye süre için isteyebileceği tazminat miktarının, işçinin altı aylık ücretinden fazla olamayacağı şeklinde anlaşılması mümkündür. Böylece Tasarının, bakiye süreye ilişkin tazminat miktarına bir sınır getirdiği ileri sürülebilir.

İkinci olarak, işçinin bakiye süreye ilişkin tazminat talebi dışında, ek bir tazminat kalemine daha yer verildiği, çünkü maddenin ilk iki fikrasında, bakiye süreye ilişkin tazminat talebinin azamî bir miktarla sınırlanmadığı, son fikradaki hükmün, işçinin altı aylık ücretiyle sınırlı ek bir tazminat olduğu ileri sürülebilir.

Hükmün gerekçesinde de açıklık bulunmamakla birlikte, kanaatimce ilk görüş yönünde, anılan maddenin son fikrasının, işçinin bakiye süreye ilişkin tazminat talebine, işçinin altı aylık geliri oranında bir sınır getirdiği kabul edilmelidir.

\section{bbb. Kıdem tazminatı}

İşverenin feshinin sözleşmeyi sona erdirdiği kabul edildiğinde, ortada bir haklı neden bulunmadığı için, işçi koşulları varsa kıdem tazminatına hak kazanacaktır. Çünkü, iş sözleşmesinin işveren tarafından, İş Kanununun 25/II. maddesi dışında feshedilmesi halinde, feshin haklı veya haksız olmasına bakılmaksızın işçinin kıdem tazminatına hak kazanacağı kabul edilmiştir ${ }^{191}$. Yargitay kararları da bu yöndedir ${ }^{192}$.

Ancak, haksız feshi temerrüt olarak nitelendiren görüşte, sözleşme sürenin sonuna kadar ayakta kalacağ 1 ve süre sonunda kendiliğinden sona ereceği için, işçinin kıdem tazminatı talep edemeyeceği sonucuna varılmaktadır. $\mathrm{Bu}$ görüşü savunan yazarlarca ayrıca, işverenin bu davranışının işçi bakımından haklı neden oluşturduğu, bu nedenle işçinin sözleşmeyi feshederek kıdem tazminatı talep edebileceği ileri sürülmüştür ${ }^{193}$.

191 Narmanlığlu, Kıdem Tazminatı, s. 390; Alpagut, Belirli Süreli, s. 189.

192 Bkz. Yargitay 9. HD, 18.03.1998, 2611/5145 say1lı kararı (IBDD, 1999/3, s. 202); 9. HD, 11.05.1993, 1992/797 E., 1993/8074 K. sayılı kararı (Güler, Belirli Süreli, s. 74, dn. 107).

193 Eyrenci, [İHU, İşK 9 (No: 2)]. 
Kusurlu imkansızlık görüşünde, sözleşmenin sonraki kusurlu imkansızlık nedeniyle sona erdiği kabul edildiği için, işçinin kıdem tazminatı talep edemeyeceği, ancak işverenin bu davranışının akde aykırı bir nitelik taşıması nedeniyle, işçinin kıdem tazminatı miktarında alacak hakkı bulunduğu ileri sürülmüştür ${ }^{194}$. Dikkat edilecek olursa bu talep, işçinin zarar kalemlerinden birini teşkil edecektir.

\section{cce. İhbar tazminatı}

İhbar tazminatı belirsiz süreli iş sözleşmesinin feshinde talep edilebilen bir tazminat olduğu için, belirli süreli iş sözleşmesinin süresinden önce haklı bir neden bulunmaksızın işverence feshedilmesi durumunda talep edileme ${ }^{195}$.

\section{ddd. Kötüniyet tazminatı}

Haklı nedenlere dayanmayan feshi alacaklının temerrüdü sayan görüşte sözleşme sona ermediği, kusurlu imkansızlık görüşünde ise, sözleşme fesihle sona ermediği için, işçinin kötüniyet tazminatı hakkı bulunmadığı kabul edilmektedir.

Haksız feshin sözleşmeyi sona erdirdiğini kabul eden görüşte ise, kötüniyet tazminatının hesabında ihbar sürelerinin dikkate alınması nedeniyle, kötüniyet tazminatının, belirli süreli iş sözleșmesinin haksız feshinde mümkün olmayacağı ileri sürülmüştür ${ }^{196}$.

194 Bkz. yuk. dn. 175.

195 Güler, Belirli Süreli, s. 72; Centel, Tankut: "Belirli Süreli İş Sözleşmesi ve İ̉bar Tazminatı (Karar İncelemesi)", Tekstil İşveren Dergisi, Nisan 2003, S. 280, s. 34. Bu yönde: Yargitay 9. Hukuk Dairesinin 09.12.2002 tarih ve 8670/23433 sayılı kararından: “... Belirli süreli hizmet akitleri; sözleşmenin kurulduğu zaman taraflar arasındaki hukuki ilişkinin sona erdiği anın bilindiği yada öngörülebildiği bir hukuki durumu düzenler. İhbar tazminat, İș Kanunu 13/C maddesinde belirsiz süreli hizmet akitlerinin sona erdirilmesinde ihbar önellerine uyulmamast hallerinde diğer tarafa ödenmek üzere öngörüldüğ̈̈ için belirli süreli hizmet akdinin haksız feshi durumunda dahi ihbar tazminatı hakk doğmaz..." (Bu karar eHukukRehberi bilgi arşivinden alınmıştır).

196 Centel, Tankut: "Belirli Süreli Hizmet Sözleşmesinin Feshi ve Kötüniyet Tazminatı (Karar İncelemesi)", Tekstil İşveren Dergisi, Şubat 2002, S. 266, s. 33; Alpagut, Değerlendirme, s. 94; Güler, Belirli Süreli, s. 73. Yargitay 9. HD 28.03.2001, 5272/4939 sayılı kararından: “... Süreli akdin feshi halinde ihbar tazminatı ve buna bağlı olarak kötüniyet tazminatı istenemez." (Tekstil İşveren Dergisi, Şubat 2002, S. 266, s. 33. Ayrıca bkz. Güler, Belirli Süreli, s. 72, dn. 103). Ancak 9. Hukuk Dairesinin 08.12.2003 tarih ve 8909/20315 sayılı kakarında belirli süreli iş sözleşmesinde de kötüniyet tazminatı istenebileceği izlenimi uyandıran ifadeler kullanılmıştır. Bu karardan: “... Davalı işveren son olarak belirli süreli hizmet akdi ile çalışan davacının kıdem tazminatı ile iş̧̧ilik alacakları yanında kalan bakiye süre ücreti için öngörülen fesih tazminatını ödemek suretiyle fesih hakkını kullanarak sözleşmeyi sona erdirmiștir. Bir bașka anlatımla davalı feshe bağlı olan ve ödenmesi gereken davact zararlarını ödemiştir. Karşılanan bu zararlar haksız feshin sonuçları olup, iş sözleşmesinin mücerret haksız feshi manevi tazminatı gerektirmez. Somut olayda feshin kötüniyetle yapıldığ kanitlanmadığ gibi Borçlar Kanunu'nun 49. maddesinde öngörülen koşullar gerçekleşmemiştir..." (Bu karar eHukukRehberi bilgi arşivinden alınmıştır). 


\section{eee. Cezaî Șart}

Belirli süreli iş sözleşmesinin süresinden önce haklı nedenler bulunmasızın işverence feshi halinde, işverenin işçiye belli miktarda parayı cezaî şart olarak ödeyeceğinin kararlaştırılması geçerli sayıldığı için, bu durumda işçi, yukarıdakiler dışında ${ }^{197}$ sözleşmede kararlaştırılmış bulunan cezaî şartı da ayrıca isteyebilirr ${ }^{198}$.

\section{2. İşci Tarafindan}

\section{a. Haklı nedenle}

Belirli süreli iş sözleşmesinin haklı nedenle işçi tarafından feshi, iş sözleşmesini sona erdirir. Bu durumda işçi kıdem tazminatına hak kazanır, ancak ihbar tazminatı alamaz ${ }^{199}$.

Eğer işçi, iş sözleşmesini ahlak ve iyiniyet kurallarına aykırılık nedeniyle feshetmişse, kıdem tazminatı dışında uğradığ 1 diğer zararlarını da isteyebilir (İș m. 26/II). Bu zarar kavramı içine, iş sözleşmesinin süresinden önce feshi nedeniyle elde edemediği ve $\mathrm{BK} \mathrm{m}$. 325'e göre hesaplanacak olan gelirinin de girdiği doktrinde haklı olarak ileri sürülmüştür ${ }^{200}$.

197 YHGK, 06.10.1978 tarih ve 1977/9-101 E., 1978/800 K. sayll kararından: "Belirli süreli hizmet akdinin haksı feshi halinde işverenin kalan süredeki aylıklart ödemeyi yüklenmesi cezai şart hükmünde olup, BK'nun 325/2. maddesinin uygulama yeri bulunmamaktadır. Ancak hakim, miktarını fahiş gördüğ̈̈ taktirde indirmekle yükümlüdür." Bu karar ve incelemesi için bkz. Elbir, [İHU, İşK. 9, (No: 3)]. Bu karar sonuç bakımından doğru olmakla birlikte, gerekçesi bakımından yerinde değildir. Çünkü, işçi yararına cezaî şartın kararlaştırılması durumunda BK m. 325/II'nin bütün uygulama alanını yitirdiğinin ileri sürülmesi, cezaî şartın temel özelliğine aykırıdır. Bilindiği gibi cezaî şart, bundan yararlanan kişiyi zararını kanıtlamaktan kurtarır. Ancak cezaî şart miktarından fazla bir zarar varsa, bunu kanıtlamak kaydıyla talep mümkündür. $\mathrm{Bu}$ nedenle, işçi kararlaştırılan cezaî şart ile, BK m. 325/II gereğince talep edebileceği kısım arasındaki farkı, bunu kanıtlamak koşuluyla talep edebilir. Bkz. ve karş. Alpagut, Belirli Süreli, s. 197; Başbuğ Aydın: "Tacir İşveren ve İş Hukukunda Cezai Şarttan İndirim”, Kamu-İş, 2003/2, Prof. Dr. Kamil Turan'a Armağan, s. 247.

198 Alpagut, Belirli Süreli, s. 196; Çelik, s. 181. Bu konuda ayrıca bkz. Özdemir, Erdem: "İş Hukukunda Eğitim Karşılığı Öngörülen Cezai Şart”, Çalışma ve Toplum Dergisi, 2005/1, s. 143-156; Süzek, Sarper: "İ̧s Akdini Fesih Hakkının Sınırlandırılması", Kamuİș Dergisi, 2002/4, s. 86 (Sınırlandırma).

199 Yargitay 9. Hukuk Dairesinin 27.10.2004 tarih ve 5632/24444 say1l kararından: “... Taraflar arasındaki işs sözleşmesinin 5. maddesinde sözleşmeyi haksız olarak fesheden tarafin karşı tarafa cezai şart ödeyeceği kararlaştırılmıştır. Sözleşmenin işçi tarafindan hakl fesih halinde cezai şartın işverence ödeneceğine dair bir düzenleme bulunmamaktadır. Sözleşmenin davacı işçi tarafindan hakl nedenle feshedildiği mahkemece kabul edildiğine göre cezai şartın hüküm altına alınması mümkün değildir..." (Bu karar eHukukRehberi bilgi arşivinden alınmıştır).

200 Güler, Belirli Süreli, s. 77. Yargitay 9. Hukuk Dairesinin 03.10.2001 tarih ve 7878/15412 sayılı kararından: “... Borçlar Kanununun 325. maddesinde, belirli süreli 


\section{b. Haklı neden bulunmaksızın}

Belirli süreli iş sözleşmesinin süresinden önce işveren tarafından haklı nedenler bulunmaksızın feshedilmesi ve bunun hukukî sonuçlarına ilişkin tartışma, aynı şekilde işçi tarafından yapılan haksız fesihte de yaşanmaktadır ${ }^{201}$. Kanaatimiz, haksız feshin iş sözleşmesini sona erdireceği yönünde olduğu için, yukarıda vardığımız sonuca uygun olarak, belirli süreli iş sözleşmesinin süresinden önce haklı neden bulunmaksızın işçi tarafından feshinin de geçerli olduğu ve iş ilişkisini sona erdirdiği yönündedir ${ }^{202}$.

Haklı neden bulunmaksızın sözleşmeyi fesheden işçi ihbar tazminatı talep edemeyeceği gibi, belirli süreli iş sözleşmesinde bu tazminat söz konusu olmadığı için, işveren de ihbar tazminatı isteyemez.

Kıdem tazminatı ise, ayrıca incelenmelidir. Kıdem tazminatına ilişskin 1475 sayılı Kanunun 14. maddesinde, kıdem tazminatı talep koşulları, iş sözleşmesinin sona erme biçimine göre düzenlenmiştir. Bu hükümde işçiye kıdem tazminatı talep etme hakkı veren diğer durumlar dışında, işçinin "muvazzaf askerlik hizmeti dolaylsıyla", "bağlı bulundukları kanunla kurulu kurum veya sandıklardan yaşlılık, emeklilik veya malullük aylığ yahut toptan ödeme almak amaciyla" veya 506 say11 Kanunun 60. maddesinde öngörülen koşullara sahip olan veya aynı Kanunun geçici II. maddesine göre yaşlılık aylığı bağlanması için öngörülen koşulları tamamlayarak, veyahut da kadın işçinin evlenmesi nedeniyle iş sözleşmesini feshetmesi durumunda, kıdem tazminatı talep edebileceği düzenlenmiştir.

Görüldüğü gibi bu hükümde, sadece iş sözleşmesinin sona erme sebepleri bakımından bir düzenleme yapılmıştır. $\mathrm{Bu}$ nedenle, iş sözleşmesinin türü ve fesih biçiminin önemli olmadığı doktrinde haklı olarak ileri sürülmüştür ${ }^{203}$. Böylece belirli süreli iş sözleşmesinde de, bu amaçlarla iş sözleşmesini fesheden işçi kıdem tazminatına hak kazanacaktır. Ancak,

hizmet akdi ile çalışan işçinin işine son verilmesi halinde geri kalan süre için ... istekte bulunabileceği öngörülmüştür. Bu madde, hakl sebeple sözleşmeyi fesheden iş̧̧i bakımından bir düzenleme getirmemişse de, daha sonraki 344 ve 345. maddelerde öngörülen kurallar işçiye böyle bir talepte bulunma hakkı vermektedir. Kaldı ki 1475 sayılı İş Kanununda bu konuda özel bir düzenlemeye yer verilmiş olup, 18/son (4857 sayılı Kanunun 26/son) maddesinde iş̧̧inin hakl nedenle sözleşmesini ... feshetmesi durumunda ayrica tazminat hakkının saklı olduğu kuralına yer verilmiștir. Bununla beraber Iş̧ Kanununda bu tazminatın nasıl belirleneceği konusunda bir açıklık bulunmadı̆̆ından, Borçlar Kanununun 325. maddesinde yazılı esaslar çerçevesinde tazminat miktarı tespit edilmelidir." (Güler, Belirli Süreli, s. 77, dn. 117).

201 Güler, Belirli Süreli, s. 78.

202 Haksız feshin sözleşmeyi sona erdirmediğini savunan yazarlara göre, bu durumda işverenin sözleşmenin sonuna kadarki işin yapılmasını talep etme hakkı, tazminat alacağına dönüşmektedir. Bkz. ve karş. Güler, Belirli Süreli, s. 78.

203 Çelik, s. 261; Alpagut, Belirli Süreli, s. 193; Güler, Belirli Süreli, s. 79. 
doktrinde savunulan bir diğer görüşe göre ${ }^{204}$, kıdem tazminatı talep etme hakkı veren ve yukarıda sayılan bu haller, iş sözleşmesinin feshi için haklı neden niteliğinde olmadığından, işçi bu nedenlere dayanarak iş sözleșmesini bildirimsiz olarak feshedemez. Aksi takdirde bu haksiz bir fesih olur. Sözleşmeyi haksız olarak fesheden işçi kıdem tazminatı da isteyemeyeceği için, bu nedenler işçiye, sadece sözleşmeyi bildirimli olarak feshetme olanağ 1 verir. Belirli süreli iş sözleşmesinde, bildirimli fesih olanağı da bulunmadığı için, bu tür iş sözleşmesinde işçi sözleşmeyi bu nedenlerle feshederse kıdem tazminatı alamayacaktır.

Belirli süreli iş sözleşmesinin işçi tarafından haklı bir neden bulunmaksızın feshi halinde, işverenin bu fesih nedeniyle uğradığı zararlarını tazmini talebine ilişkin tek hüküm, İş Kanununun 23. maddesinde yer almıştır ${ }^{205}$. "Yeni İşverenin Sorumluluğu" kenar başlığını taşıyan bu maddede işçinin, yeni bir işe girmek amacıyla belirli süreli iş sözleşmesinin süresinden önce feshetmesi halinde, işverenin uğradığı zarardan işçi ile birlikte yeni işverenin de bazı koşullarda sorumlu olduğu düzenlenmiştir ${ }^{206}$. İşçinin ve yeni işverenin, müteselsil olarak sorumlu oldukları hükümde belirtilmiștir.

Bunların yanında, iş sözleşmesinde bulunan ve işçinin, belirli süreli iş sözleşmesini süresinden önce haklı nedenler bulunmaksızın feshetmesi halinde belli miktar parayı cezaî şart olarak ödeyeceğine ilişkin hükümlerin geçerliliği sorunu da incelenmelidir ${ }^{207}$. Yargitay, iş sözleşmesine, sadece işçi

204 Alpagut, Belirli Süreli, s. 192, dn. 486'da anılan yazarlar.

$205 \mathrm{Bu}$ nedenle, işçinin sorumluluğunun bu hükümle sınırlı olduğu, işverenin bu hüküm dışında herhangi bir tazminat talebinin dinlenmemesi gerektiği doktrinde ileri sürülmüştür. Güler, Belirli Süreli, s. 80. Ancak kanaatimce, belirli süreli iş sözleşmesinin süresinden önce haklı neden bulunmaksızın işçi tarafından feshi halinde, işçinin, işverenin zararlarını BK m. 96 gereğince tazmin etmesi gerektiği kabul edilmelidir. Bu yönde: Alpagut, Belirli Süreli, s. 191; Tutucu, Aslı/Odaman, Serkan: "İş Kanunu 15. Madde Uyarınca İşyerini Terkeden İşçiyi Çalıştıran Yeni İşverenin Sorumluluğunun Koşulları ve Hukuki Niteliği”, Prof. Dr. Nuri Çelik’e Armağan, C. 2, İstanbul 2001, s. 1389, dn. 10 ve orada anılan yazarlar).

Türk Borçlar Kanunu Tasarısının 443. maddesiyle, bu konuda ișçi aleyhine bir tazminata yer verildiği görülmektedir. Bu hükme göre, işçi haklı bir neden bulunmaksızın işe başlamaz veya aniden işi bırakırsa, aylık ücretinin dörtte biri oranında bir tazminatı, işverenin istemi üzerine ona ödemekle yükümlü tutulmuştur. Ayrıca, işverenin ek zararları için de tazminat isteyebileceği belirtilmiştir. Maddenin ikinci fikrasında, işverenin zarara uğramaması veya daha az zarara uğraması durumunda, hakimin tazminat miktarını indirebileceği düzenlenmiştir. Maddenin son fikrasında ise, işverenin bu talebinin, 30 günlük hak düşürücü süreye bağlandığı görülmektedir.

206 Bu konuda ayrıntılı bilgi için bkz. Tutucu/Odaman, s. 1385 vd.

207 Bu konuda ayrıntılı bilgi için bkz. Soyer, Polat: "Hizmet Akdinin İşçi Tarafından Feshi İçin Öngörülen Cezai Şartın Geçerliliği Sorunu”, Prof. Dr. Turhan Esener’e Armağan, Ankara 2000, s. 363 vd. (Cezai Şart); Özdemir, s. 143 vd.; Engin, s. 90; Başbuğ, s. 239 vd. 
aleyhine konulan cezaî şartın geçerli olmadığın $1^{208}$, aynı hükmün işveren aleyhine konulması durumunda ise geçerli olacağın ${ }^{209}$, ancak bu durumda da işçi aleyhine olan cezaî şart miktarının, işveren aleyhine olandan fazla olması durumunda, işçinin cezaî şartının, işverenin cezaî şartından fazla olan kısmının geçersiz olduğu kabul edilmektedir ${ }^{210}$. Nitekim Türk Borçlar Kanunu Tasarısının 424. maddesinde, iş sözleşmelerinde yar alan cezaî şartın, ancak her iki taraf için de öngörülmesi durumunda geçerli olacağı hüküm altına alınmıştır.

Sadece işçi aleyhine konulan cezaî şartın geçersiz kabul edilmesinin yerinde olduğu, ancak genellikle yurt dışına eğitim amacıyla gönderilen ve büyük masraflar yapılan işçiler aleyhine tek yanlı olarak konulan cezaî şartın geçerli olması gerektiği doktrinde ileri sürülmüştür ${ }^{211}$. Ancak yine doktrinde, işçiye harcanan emek ve masraf karşısında, kararlaştırılan zorunlu çalışma süresinin ve cezaî şart miktarının hakkaniyet ölçütünü aşmaması gerektiği ileri sürülmüşsür ${ }^{212}$. Bu durumda, kısmî butlan yaptırımının uygulanması söz konusu olabilir.

208 Bu yönde: YHGK, 17.12.1997, 9-816/1062 sayılı kararı (Tekstil İşveren Dergisi, 1997/3, s. 15); Yargitay 9. HD, 03.06.1997, 7529/10660 sayılı karar1 (YKD, 1997/9, s. 1427). Ancak sadece işçi lehine konulan cezaî şartın geçerli olduğu kabul edilmektedir. $\mathrm{Bu}$ yönde: Yargıtay 9. HD, 27.12.1999, 17469/20361 sayılı kararı (Çimento İşveren Dergisi, 2000/3, s. 38).

209 Bu yönde: 30.05.2002, 1228/9321 say1lı kararı (Çimento İşveren Dergisi, 2002/9, s. 42).

210 Soyer, Cezai Şart, s. 364; Süzek, Sınırlandırma, s. 92; Başbuğ, s. 246. Bu yönde: Yargitay 9. HD, 29.03.1997, 1996/22867 E., 1997/6102 K. (Çelik, s. 181, dn. 46).

211 Soyer, Cezai Şart, s. 368; Çelik, s. 182; Süzek, Sınırlandırma, s. 92; Şahlanan, Seminer, s. 53; Özdemir, s. 147; Alpagut, Değerlendirme, s. 94, 95; Engin, s. 91, 92. Bu yönde: “... Dairemizce sadece işveren yararına yer alan cezai şartın kural olarak geçersiz olduğu kabul edilmektedir. Ancak ... ișveren büyük masraflar yaparak yurt içinde veya yurt dışında eğitime veya bir kursa tabi tutmuş yani onu yetiştirmişse, işverenin belli bir süre işçiyi işyerinde çalıştırmaya mecbur tutması haklı görülmelidir. - Somut olayda cezai şart böyle bir nedenle konulmuş bulunduğuna göre, salt tek taraflı olması sonucu onun geçersizliğinin kabulü hakkaniyet ve adalet ilkeleri ile bağdaşmaz." [Yargitay 9. HD, 29.03.2000, 507/4100, (Bu karar ve Polat Soyer'in incelemesi için bkz. Çimento İşveren Dergisi, Eylül 2000, s. 19 vd.)].

212 Çelik, s. 182; Engin, s. 92; Özdemir, s. 148. Bunun dışında iş̧̧i aleyhine olarak sözleşmeye konulan bu tür cezaî şart koşullarının geçerli olabilmesi için doktrin ve mahkeme kararlarıyla getirilmiş esaslar şöylece sıralanabilir: 1. Öncelikle verilen eğitim ile iş̧̧inin ödemesi gereken bedel arasında denge bulunmalıdır. 2. İşçi belli bir süre çalışmışsa, cezaî şartın tenkisinde bu süreye göre oranlama yapılmalıdır. 3. Cezaî şartın, iş̧̧inin fesih hakkını hukuka aykırı biçimde sınırlamaması gerekir. Ayrıca, cezaî şartın tenkis edilemeyeceğine ilişkin kayıtların geçerli olmadığ $\breve{g}_{1}$ ve işçiye verilen eğitimin sadece işverene değil, aynı zamanda işçiye de yararlı olması gerektiği de kabul edilmektedir. Bkz. ve karş. Soyer, Cezai Şart, s. 371 vd.; Süzek, Sınırlandırma, s. 93; Engin, s. 92; Başbuğ, s. 244, 249. 
Eğitim giderleri dışında, sadece işçi aleyhine konulan cezaî şartın geçerli olacağı diğer durum olarak doktrinde, belirli süreli iş sözleşmesinin işçi tarafından haksız feshi gösterilmiştir ${ }^{213}$. Bu görüşe göre, belirli süreli iş sözleşmesinin işveren tarafından haksız feshi halinde işçi, sürenin sonuna kadarki ücreti tutarında bir tazminatı talep edebilecekken, iş̧̧inin haksız feshinde, işverenin, zararını kanıtlaması koşuluyla tazminat isteyebileceği kabul edildiği için, sadece işçi aleyhine konulan cezaî şart aslında tek taraflı olmayacaktır. Böylece, belirli süreli iş sözleşmesinin işçi tarafından haksız feshi durumu için kararlaştırılan cezaî şart kural olarak geçerli kabul edilmelidir. Ancak aynı görüşte bunun sınırlarının da bulunduğu ifade edilmiştir. Mesela, cezaî şartın fahiş olmamas ${ }^{214}$ ve işverenin uğrayabileceği olası zararları aşırı derecede aşmaması gerektiği kabul edilmiştir.

\section{SONUÇ}

Belirli süreli iş sözleşmesini topluca değerlendirmeye çalıştı̆̆ımız bu çalışmamızda vardığımız sonuçlar maddeler halinde aşağıda özetlenmiştir.

1. Belirli süreli iş sözleşmesinin varlığından söz edilebilmesi için, öncelikle iş sözleşmesinin taraflarca süreye bağlanması gerekmekte, ayrıca sözleşmenin belirli süreli olmasını haklı gösteren objektif nedenlerin bulunması da aranmaktadır. Bu nedenle, iş sözleşmesinin süreye bağlanması veya objektif nedenlerin bulunması, belirli süreli iş sözleşmesinin varlığından söz edilebilmesi için yeterli değildir. Bu iki unsur aynı anda gerçekleşmelidir.

2. İş sözleşmesinin süreye bağlanması açık olabileceği gibi, örtülü biçimde de yapılabilir. Ancak sözleşmenin süresinin örtülü biçimde kararlaştırıldığı durumlarda, belirli süreli iş sözleşmesinden söz edilebilmesi için, öncelikle sözleşmenin amacının işçi tarafından anlaşılabilmesi, işin amacının veya niteliğinin aynı zamanda bir sürelendirme niteliği taşıması ve sözleşmenin sona ereceği tarihin, sözleşmenin yapıldığ 1 sırada işçi tarafından objektif olarak öngörülebilir olması gerekmektedir. Aksi halde, sözleşme belirsiz süreli sayılacaktır.

3. 4857 sayılı İş Kanununu, iş sözleşmesinin ilk yapıldığı sırada dahi, objektif nedenlerin varlığını aradığı için, her belirli süreli iş sözleşmesinde bu koşulların varlığı özel olarak incelenmelidir. Objektif nedenler Kanunda saymaca yöntemiyle belirtildiği için, somut olayın özelliklerine göre, ortada iş sözleşmesinin belirli süreli olarak yapılmasını haklı gösteren nedenlerin bulunması, taraflara belirli süreli iş sözleşmesi yapma yetkisi verecektir.

213 Soyer, Cezai Şart, s. 366; Engin, s. 91; Başbuğ, s. 246; Alpagut, Belirli Süreli, s. 198.

214 Bu konuda BK m. 325/II hükmünün yol gösterici kabul edilebileceği hakkında bkz. Soyer, Cezai Şart, s. 367; Engin, s. 91, 92. 
4. Yapılacak olan işin nitelikli bir iş olması veya işçinin eğitim amacıyla yurt dışına gönderilmiş bulunması, o işle ilgili iş sözleşmelerinin belirli süreli yapılması için tek başına yeterli bir objektif neden sayılmamalıdır. Mesela, yurt dışına gönderilen işçiler için, asgarî süreli iş sözleşmeleri yapılması yoluyla, işverenin işçiyi belli bir süre kendisine bağlaması mümkün olduğu için, belirli süreli iş özleşmesi yerine, anılan türden iş sözleşmeleri yapılmalıdır.

5. Deneme amacı, tek başına objektif neden sayılmamalıdır. Ancak bu sonucun kabulü için, deneme amaçlı sözleşmenin süresinin İş Kanununun 15. maddesindeki azamî süreyi aşması aranmalıdır.

6. İşçinin, belli bir yaşa geldiğinde veya emeklilik koşullarını tamamlaması durumunda iş sözleşmesinin sona ereceğinin kararlaştırılması, sözleşmeyi belirli süreli hale getirmez.

7. Yapılacak olan işin niteliği, belirli süreli iş sözleşmesi yapılması için objektif neden oluşturabilir. Mesela mevsimlik işler, niteliği gereği, belirli süre devam eden işler olduğu için, belirli süreli iş sözleşmesi yapılması için objektif neden sayılmalıdır.

8. Objektif nedenler bulunmamasına rağmen iş sözleşmesinin taraflarca bir süreye bağlanması durumunda, ilişkinin baştan itibaren belirsiz süreli iş sözleşmesine dayandığ 1 kabul edilmelidir. Ancak gerek tarafların iradeleri, gerekse de işçinin korunması ilkesi gereğince, bu tür sözleşmelerde, bildirimli fesih hakkının taraflarca belirlenen süreyle sınırlı olarak ortadan kaldırıldığı kabul edilmelidir. Diğer bir ifadeyle, objektif neden yokluğu, sözleşmeyi asgarî süreli iş sözleşmesi haline getirir.

9. Belirli süreli iş sözleşmesinin süresi bir yıl veya daha fazla ise, bu sözleşmenin yazılı şekilde yapılması gerekir. Bu şekil geçerlilik koşuludur. Ancak, iş hukukunun özellikleri dikkate alınarak, bu şekle bağlanmadan yapılan iş sözleşmesi ne baştan itibaren, ne de ileriye yönelik olarak geçersiz sayılmalıdır. Tahvil kurumu gereğince, bu tür sözleşmeler belirsiz süreli sözleşme olarak ayakta tutulmalıdır.

10. Belirli süreli iş sözleşmesinde sürenin dolmasına rağmen işçinin çalışmaya, işverenin de çalıştırmaya devam etmesi durumunda, iş sözleşmesinin zımnen yenilendiği kabul edilmelidir. Ancak, yenilenen iş sözleşmesinin belirli süreli olarak kabulü için, objektif haklı nedenlerin varlığı aranmalıdır.

11. Haklı nedenlere dayanmayan fesih bildirimlerinin sözleşmeyi sona erdirdiğinin kabul edilmesinin, iş hukukunun özelliklerine daha uygun olacağı kanaatinde olduğumuz için, bu durumda işçinin bakiye süreye ilişkin talebinin tazminat niteliğinde olduğu ve işçinin kidem tazminatı isteyebileceği kabul edilmelidir. 
12. Sadece işçi aleyhine kararlaştırılan cezaî şart kural olarak geçersiz olmakla birlikte, sözleşmenin belirli süreli olması durumunda, bunun geçerli olması gerektiği kabul edilmelidir. Çünkü bu durumda şeklen tek taraflılık görünse bile, gerçekte cezaî şart, işçinin bakiye süreye ilişkin talebinin karşılığ 1 olarak kabul edilmektedir. Ancak bu cezaî şartın üst sınırı, işçinin BK m. 325/II gereğince talep edebileceği tazminat olmalıdır. 


\section{KAYNAKÇA}

Alpagut, Gülsevil: "4857 Sayılı Yasa Çerçevesinde Belirli Süreli İş Sözleşmesi”, Mercek Dergisi, Ocak 2004/33, s. 73-91. (4857 Sayılı Yasa)

Alpagut, Gülsevil: "Ferdi İş İlişkisinin Sona Ermesi ve Kıdem Tazminatı Açısından Yargıtay'ın 2001 Yılı Kararlarının Değerlendirilmesi”, Yargıtay'ın İş Hukukuna İlişkin Kararlarının Değerlendirilmesi 2001, Ankara 2003, s. 87 vd. (Değerlendirme)

Alpagut, Gülsevil: "Hizmet Sözleşmesinin Bozucu Şarta Bağlanması", Prof. Dr. Turhan Esener'e Armağan, Ankara 2000, s. 413 vd. (Bozucu Şart)

Alpagut, Gülsevil: Belirli Süreli Hizmet Sözleşmesi, İstanbul 1998. (Belirli Süreli)

Arslan, Arzu: "Yargıtayın Belirli/Belirsiz Süreli Hizmet Sözleşmesi Nitelendirmesine İlişkin Bir Kararı Üzerine", Prof. Dr. Nuri Çelik'e Armağan, C. 2, İstanbul 2001, s. 1046 vd.

Başbuğ, Aydın: “Tacir İşveren ve İş Hukukunda Cezai Şarttan İndirim”, Kamu-İş, 2003/2, Prof. Dr. Kamil Turan'a Armağan, s. 239 vd.

Centel, Tankut: "Belirli Süreli Hizmet Sözleşmesinin Feshi ve Kötüniyet Tazminatı (Karar İncelemesi)", Tekstil İşveren Dergisi, S. 266, Şubat 2002, s. 33.

Centel, Tankut: "Belirli Süreli İş Sözleşmesi ve İhbar Tazminatı (Karar İncelemesi)", Tekstil İşveren Dergisi, S. 280, Nisan 2003, s. 34.

Centel, Tankut: "Belirli Süreli İş Sözleşmesinin Yenilenmesi (Karar İncelemesi)", Tekstil İşveren Dergisi, S. 284, Ağustos 2003, s. 34.

Çelik, Nuri: İş Hukuku Dersleri, B. 17, İstanbul 2004.

Demir, Fevzi: Yargıtay Kararları Işı̆̆ında İş Hukuku ve Uygulaması, İzmir 2003.

Ekmekçi, Ömer: "26 Haziran 2002 Tarihli İş Kanunu Tasarısının Bazı Hükümleri Üzerine", Çalışma Hayatımızda Yeni Dönem Seminer Notları, 25-29 Eylül 2002 Marmaris, Türkiye Toprak, Seramik, Çimento ve Cam Sanayi İşverenleri Sendikası Yayını, s. 65-96.

Ekonomi, Münir: "Belirli Süreli Hizmet Akdinin Hukuka Uygunluğu", Türkİsviçre Hukukunda Belirli Süreli Hizmet Akitlerinin Hukuki Sorunları, Rehbinder/Ekonomi, İstanbul 1979, s. 1-20. (Hukuka Uygunluk)

Ekonomi, Münir: "Kıdem Tazminatına Hak Kazanılan Hallerde Fesih Kavramı ve Türleri”, Kamu-İş Dergisi, Ocak 1990, s. 10 vd.

Ekonomi, Münir: "Zincirleme Hizmet Akitlerinin Belirsiz Süreli Hizmet Akdine Dönüşemeyeceği Haller ve Sonuçları”, [ïHU, İşK 9, (No: 4)].

Ekonomi, Münir: Genel Görüşme, Yargitayın İş Hukukuna İlişkin 1998 Kararlarının Değerlendirilmesi, İstanbul 2000.

Elbir, Halid Kemal: "Belirli Süreli Hizmet Akdinin İşverence Haksız Feshi Halinde Cezai Şart”, [IHHU, İşK 9, (No: 3)]. 
Engin, Murat: "İş Hukuku Uygulamasında Borçlar Kanunu", İstanbul Barosu Çalışma Hukuku Komisyonu Bülteni, 2001/5, s. 83 vd.

Ertürk, Şükran: "Türk ve Alman Hukukunda Belirli Süreli İs Akitlerine Genel Bir Bakış”, Prof. Dr. Turhan Esener’e Armağan, Ankara 2000, s. 225.

Esener, Turhan: "Hukuki Muamelelerde Tahvil", AÜHFD, 1959/1-4, s. 234 vd.

Eyrenci, Öner / Taşkent, Savaş / Ulucan, Devrim: Bireysel İş Hukuku, İstanbul 2004.

Eyrenci, Öner: "4857 Sayılı İș Kanunu ile Getirilen Yeni Düzenlemeler Genel Bir Değerlendirme", Legal İş Hukuku ve Sosyal Güvenlik Hukuku Dergisi, 2004/I, s. 15 vd. (Genel Değerlendirme)

Eyrenci, Öner: "Belirli Süreli Hizmet Akdinin İşverence Feshedilmesinin Hukuki Sonuçları", [ïHU, İşK 9, (No: 2)].

Eyrenci, Öner: "Hukuka Uygun Belirli Süreli Hizmet Akitlerinin Türleri”, Türkİsviçre Hukukunda Belirli Süreli Hizmet Akitlerinin Hukuki Sorunları, Rehbinder/Ekonomi, İstanbul 1979, s. 57. (Belirli Süreli)

Güler, Mikdat: “Belirli Süreli İş Sözleşmesi”, Legal İş Hukuku ve Sosyal Güvenlik Hukuku Dergisi, 2005/5, s. 28-82. (Belirli Süreli)

Güler, Mikdat: "Belirli Süreli İş Sözleşmesinde Objektif Neden Kavramı ve Çalışma Koşullarının Esaslı Tarzda Değiştirilmesi - Karar İnceleme-”, Legal İş Hukuku ve Sosyal Güvenlik Hukuku Dergisi, 2004/2, s. 545. (Objektif Neden)

Kaneti, Selim: Hukuki İşlemlerin Çevrilmesi, İstanbul 1972.

Keser, Hakan: “4857 Sayılı İK'na Göre İşverenin İş Sözleşmesi Yapma ve İş İlişkilerinde Eşit İşlem Yapma Yükümlülükleri ve Bunlara Aykırı Davranması Durumunda Karşılaşacağı Yaptırımlar", Kamu-İş Dergisi, 2004/3, s. 37 vd.

Meyer, Daniel: "İsviçre Hukukunda Hizmet Akitlerinin Uyulması Zorunlu Olmayan Süreye Bağlanmaları”, (Çev. Eyrenci, Öner), Türk-İsviçre Hukukunda Belirli Süreli Hizmet Akitlerinin Hukuki Sorunları, Rehbinder/Ekonomi, İstanbul 1979, s. 21 vd.

Mollamahmutoğlu, Hamdi: “4857 Sayılı Yeni İş Kanunu'nun Getirdiği Önemli Bazı Yenilikler", Kamu-İs İş Hukuku ve İktisat Dergisi, 2004/4, s. 1 vd.

Narmanlığlu, Ünal: "Aralıklarla Kurulmuş İş Sözleşmeleriyle Çalışan İşçinin Kıdem / Hizmet Süresinin Belirlenmesine İlişkin Kanuni Esaslar ve Yargitayın Tutumu", Prof. Dr. Halid Kemal Elbir'e Armağan, İstanbul 1996, s. 307 vd. (Aralıklarla Kurulmuş İş Sözleşmesi)

Narmanlıŏlu, Ünal: "Belirli Süreli İş Sözleşmesiyle Çalışan İşçinin Sözleşmesinin İşverence Haksız Halinde Kıdem Tazminatı Talep Hakkı", Prof. Dr. Turhan Esener'e Armağan, Ankara 2000, s. 381 vd. (Kıdem Tazminatı)

Narmanlığlu, Ünal: İş Hukuku Ferdi İş İlişsileri I, İzmir 1998. (İş Hukuku)

Özdemir, Erdem: "İş Hukukunda Eğitim Karşıllı̆ı Öngörülen Cezai Şart”, Çalışma ve Toplum Dergisi, 2005/1, s. 143-156. 
Rehbinder, Manfred: "Hizmet Akitlerinin Süreye Bağlanmasını Haklı Kılan Objektif Nedenler”, (Çev. Eyrenci, Öner), Türk-İsviçre Hukukunda Belirli Süreli Hizmet Akitlerinin Hukuki Sorunları, Rehbinder/Ekonomi, İstanbul 1979, s. 37 vd.

Soyer, Polat: "Hizmet Akdinin İşçi Tarafından Feshi İçin Öngörülen Cezai Şartın Geçerliliği Sorunu”, Prof. Dr. Turhan Esener'e Armağan, Ankara 2000, s. 363 vd. (Cezai Şart)

Stöckli, Jean - Fritz: "Belirli süreli Hizmet Akdinin Sona Ermesi”, (Çev. Ulucan, Devrim), Türk-İsviçre Hukukunda Belirli Süreli Hizmet Akitlerinin Hukuki Sorunlar1, Rehbinder/Ekonomi, İstanbul 1979, s. 77 vd.

Sur, Melda: "Belirli Süreli Hizmet Akitlerinin Sona Ermesine İlişkin Bazı Yargı Kararlarının Değerlendirilmesi”, AÜSBFD, 1985/1-4, s. 269 vd.

Sümer, Haluk Hadi: "Belirli Süreli Hizmet Sözleşmelerinde Haksız Feshin Hukuki Sonuçları”, TÜHİS, Şubat 1992/8, s. 3 vd.

Süzek, Sarper: "İş̧ Akdini Fesih Hakkının Sınırlandırılması”, Kamu-İş Dergisi, 2002/4, s. 73 vd. (Sinırlandirma)

Süzek, Sarper: İş Hukuku, İstanbul 2005. (İş Hukuku)

Şahlanan, Fevzi: “4857 Sayılı Yeni İş Kanunu Değerlendirme Konferansı Notları”, 12-13 Temmuz 2003 Bolu, Türk İş Yayını, s. 66 vd. (Konferans Notları)

Şahlanan, Fevzi: "Yeni İş Kanunu Ne Getiriyor Semineri”, 3 Temmuz 2003 İzmir, TİSK. Yayını, s. 29 vd. (Seminer)

Taşkent, Savaş: "Belirli Süreli Hizmet Akdi ve Kıdem Tazminatına Hak Kazanma", [İHU, İşK 9 (No: 5)].

Tuncay, Can: “İş Sözleşmesinin Türleri ve Yeni İstihdam Biçimleri”, Yeni İş Yasası Sempozyumu, İstanbul Barosu - Galatasaray Üniversitesi, İstanbul 2003, s. 125 vd. (İş Sözleşmesi Türleri)

Tunçomă̆, Kenan/Centel, Tankut: İş Hukukunun Esasları, İstanbul 2004.

Tutucu, Aslı/Odaman, Serkan: “İş Kanunu 15. Madde Uyarınca İşyerini Terkeden İşçiyi Çalıştıran Yeni İşverenin Sorumluluğunun Koşulları ve Hukuki Niteliği”, Prof. Dr. Nuri Çelik’e Armağan, C. 2, İstanbul 2001, s. 1385-1413.

Uçum, Mehmet: Yeni İş Kanunu Seminer Notları, İstanbul 2003.

Ulucan, Devrim: “4857 Sayılı Kanuna Göre İş Sözleşmesi Türleri”, Yeni İş Yasası Seminer Notları ve İş Kanunu, Türkiye Toprak, Seramik, Çimento ve Cam Sanayi İşverenleri Sendikası Yayını, 25-29 Haziran 2003 Çeşme, s. 35-66. (İş Sözleşmesi Türleri)

Ulucan, Devrim: "Belirli Süreli Hizmet Akdinin Sona Ermesi”, Türk-İsviçre Hukukunda Belirli Süreli Hizmet Akitlerinin Hukuki Sorunları, Rehbinder/Ekonomi, İstanbul 1979, s. 95 vd. (Sona Erme)

Ulucan, Devrim: "Belirli Süreli Hizmet Akdinin Sona Ermesinde İhbar Tazminatı İstenememesi”, [İHU, İşK 13 (No: 10)].

Ünal, Ayşe: “AB'de Belirli Süreli Çalışma”, Kamu-İş, 2005/1, s. 75 vd. 